DANMARKS GEOLOGISKE UNDERS $\varnothing$ GELSE · SERIE A · NR. 11 MILJØMINISTERIET · Geological Survey of Denmark

\title{
Seismic stratigraphy and tectonic evolution of
}

the Lower Cretaceous in the Danish Central Trough

BY

OLE VALDEMAR VEJBAEK

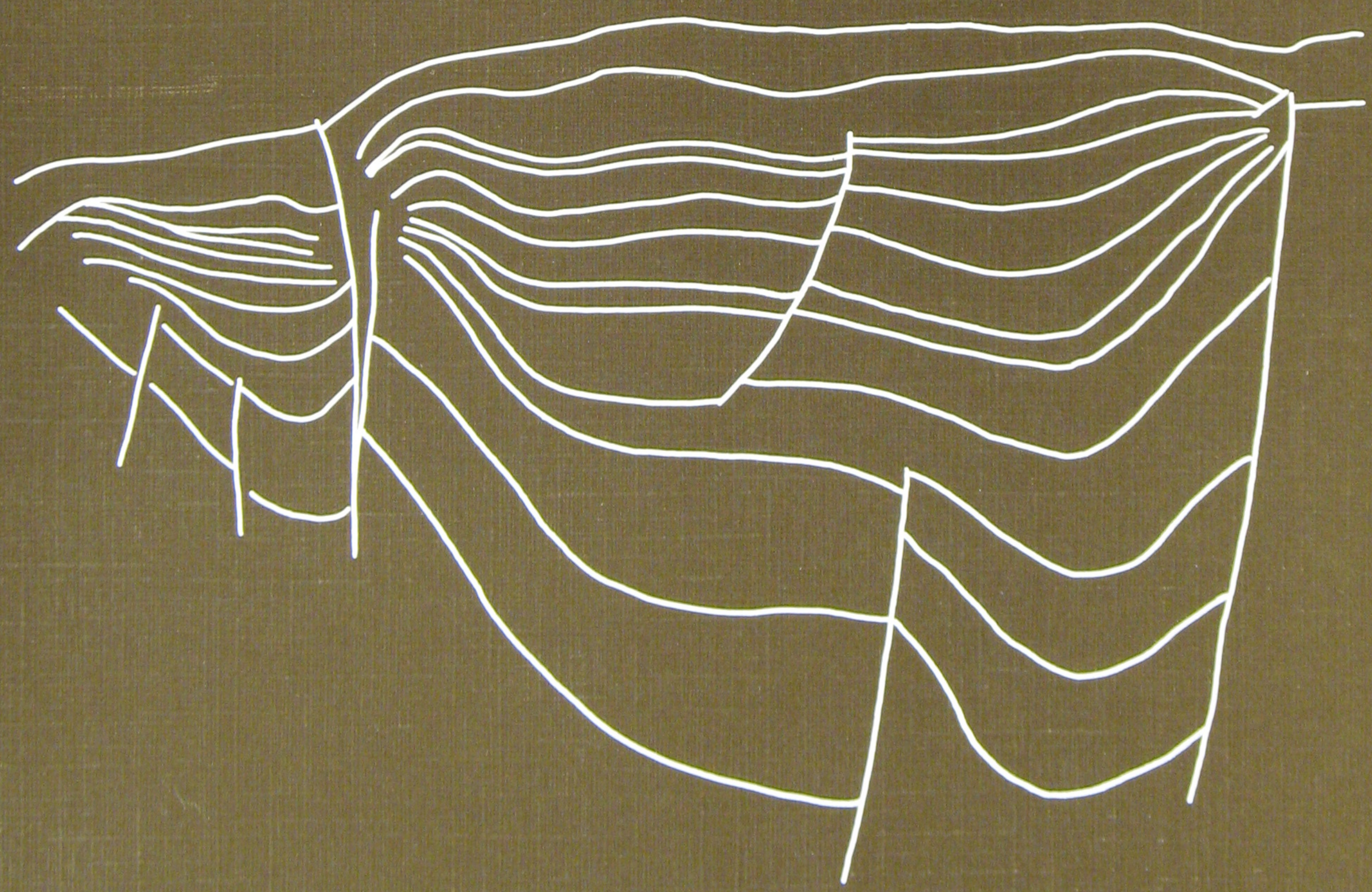

I kommission hos C. A. Reitzels forlag · København 1986 


\section{Seismic stratigraphy and tectonic evolution of the Lower Cretaceous in the Danish Central Trough}

BY

OLE VALDEMAR VEJBÆK

I kommission hos C. A. Reitzels forlag · København 1986 


\section{A contribution to the \\ EFP-83 project: \\ Jurassic-Lower Cretaceous stratigraphy \\ and basin development of the Danish North \\ Sea sector.}

Key-words:

Lower Cretaceous, Seismic

Stratigraphy, North Sea, Tectonics

with 11 maps

Vignette:

East-West section through the Tail End Graben

DGU Serie A nr. 11

ISBN 87-421-0743-1

ISSN 0901-0270

Oplag: 1200

Tryk: AiO Tryk as, Odense

Tegning: Helle Zetterwall, Lise-Lotte Thorsen

Dato: 1986-12-01

Ole Valdemar, Vejbæk, DGU

Thoravej 31, 2400 København NV

Redaktion: Leif Banke Rasmussen

(C) Danmarks Geologiske Undersøgelse,

Thoravej 31, DK-2400 København NV 


\section{Preface}

The present paper is one of several reports issued as the result of a research project carried out by the Geological Survey of Denmark in cooperation with the Geological Institute at the University of Copenhagen. The project has been financed by special contributions given by the Ministry of Energy for the period 1st of August 1983 to 31st of December 1985.

The project was entitled "Jurassic - Lower Cretaceous stratigraphy and basin development of the Danish North Sea sector". It has been decided to limit the study area to the Danish Central Trough, and furthermore the effort has been concentrated on the Middle Jurassic, the Upper Jurassic, and the Lower Cretaceous.

The scope of the project was to coordinate analyses of the stratigraphy, facies development and burial history in order to create a basis for predicting possible occurrences of reservoir rocks. The following reports (including the present one) will be printed in the series published by the Geological Survey of Denmark and issued in 1986 and 1987:

Frandsen, N.: Middle Jurassic deltaic and coastal deposits in the Lulu-1 well of the Danish Central Trough.
Heilmann-Clausen, C.: Lower Cretaceous dinoflagellate biostratigraphy in the Danish Central Trough.

Hoelstad, T.: Palynology and palynofacies analyses of the Middle Jurassic to Lower Cretaceous in the Danish Central Trough.

Hoelstad, T.: Palynology of the Middle Jurassic Lower Graben Sand Formation of the U-1 well, Danish Central Trough.

Jensen, T.F., Holm, L., Frandsen, N. \& Michelsen, O.: Jurassic - Lower Cretaceous lithostratigraphic nomenclature for the Danish Central Trough.

Michelsen, O., Vejbæk, O.V., Frandsen, N., Holm, L., Jensen, T.F. \& Møller, J.J.: Jurassic - Lower Cretaceous of the Danish Central Trough; - depositional environments, tectonism, and reservoirs.

Møller, J.J.: Seismic structural mapping of the Middle and Upper Jurassic in the Danish Central Trough.

Poulsen, N.: Callovian (Jurassic) to Ryazanian (Cretaceous) dinoflagellate biostratigraphy of the Danish Central Trough.

Thomsen, E.: Lower Cretaceous nannofossil biostratigraphy in the Danish Central Trough.

Vejbæk, O.V.: Seismic stratigraphy and tectonic evolution of the Lower Cretaceous in the Danish Central Trough.

DGU, 30th December 1985

Olaf Michelsen 


\section{Contents}

1. Abstract $\ldots \ldots \ldots \ldots \ldots \ldots \ldots \ldots \ldots \ldots \ldots \ldots 7$

2. Introduction $\ldots \ldots \ldots \ldots \ldots \ldots \ldots \ldots \ldots$

3. Setting $\ldots \ldots \ldots \ldots \ldots \ldots \ldots \ldots \ldots \ldots \ldots \ldots \ldots$

3.1. The Grensen Nose and the Outer Rough

Basin .

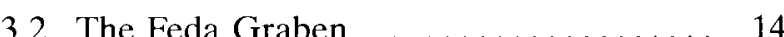

3.3. The Gertrud Graben ............... . 14

3.4. The Arne-Elin Graben . . . . . . . . . . 14

3.5. The Tail End Graben............... 17

3.6. The Salt Dome Province............ 17

4. Seismic subdivision of the Lower Cretaceous . 26 4.1. Unit LCA ................ 31
4.2. Unit LCB ................ 34

4.3. Unit LCC ................ 35

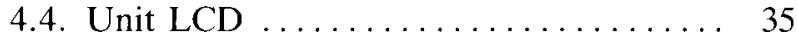

4.5. Unit LCE................ 36

4.6. Unit LCF . . . . . . . . . . . . . . 39

5. Discussion.................... 42

5.1. Tectonic evolution ............. 42

5.2. Depositional history ............ 42

6. Acknowledgements................ 44

7. References ................... 45

8. Pertinent Information on the data base .... . 46 


\section{Abstract}

The Lower Cretaceous sequence of the Danish Central Trough has been studied by the use of seismic stratigraphic analysis. The sequence has been subdivided into 6 seismic stratigraphic units named LCA, LCB, LCC, LCD, LCE and LCF. The studied area includes the Feda Graben, the Gertrud Graben (new name), the Tail End Graben, the Arne-Elin Graben (new name) and the Salt Dome Province, whereas the Grensen Nose and the Outer Rough Basin are not included. These basins are separated by the Inge High, the Mads High, the Gert Ridge (new name), the Mandal High, the Heno Plateau (new name) and the Pollerne Ridge (new name).

The fault controlled subsidence of the Lower Cretaceous basins is claimed to have been governed by left lateral transtensional wrenching. This wrenching gradually ceased and gave way to regional subsidence with intermittent events of inversion resulting from right lat- eral transpressive wrenching in the Late Cretaceous and Early Tertiary. The first weak inversion is shown to have occurred in the Late Hauterivian.

Sedimentation was influenced by a general gradual relative rise in sea-level starting with a low in the Volgian - Early Ryazanian times coeval with the deposition of the Farsund Formation and culminating in the Late Cretaceous.

At the beginning of the Early Cretaceous gravity flow became an important depositional mechanism and resulted in preferred deposition in topographical lows, which were generated by simple tensional block-faulting or by wrench-induced, rapid local subsidence. As tectonic activity decreased and the clastic source areas became more remote and worn down, depocentres became less pronounced, especially with the last unit of the Lower Cretaceous. 


\section{Introduction}

The Lower Cretaceous of the Central North Sea has hitherto been treated as one sequence in seismic interpretations (e.g. Andersen et al. 1982, Michelsen and Andersen 1983, Gowers and Sæbøe 1985, Hancock 1982). The sequence has, however, been further subdivided lithostratigraphically into the Valhall Formation, which constitutes the bulk of the sequence, the Tuxen Formation, the Sola Formation and the Rødby Formation (Jensen et al. in press).

In the present paper the Lower Cretaceous of the Danish part of the Central Trough has been studied according to the principles of seismic sequence analysis
(Vail et al. 1977). The sequence has been subdivided into the smallest mappable units, which are separated from the adjacent units by unconformities characterized by toplap, truncation, downlap or onlap of internal reflectors. This has been done mainly without reference to well-data, which means that the units are entirely seismically defined. Two of the internal Lower Cretaceous seismic unit boundaries have been correlated with log "motifs" which therefore have served as secondary tools for correlation.

On this basis the Lower Cretaceous has been subdivided into six units in the present paper of which the

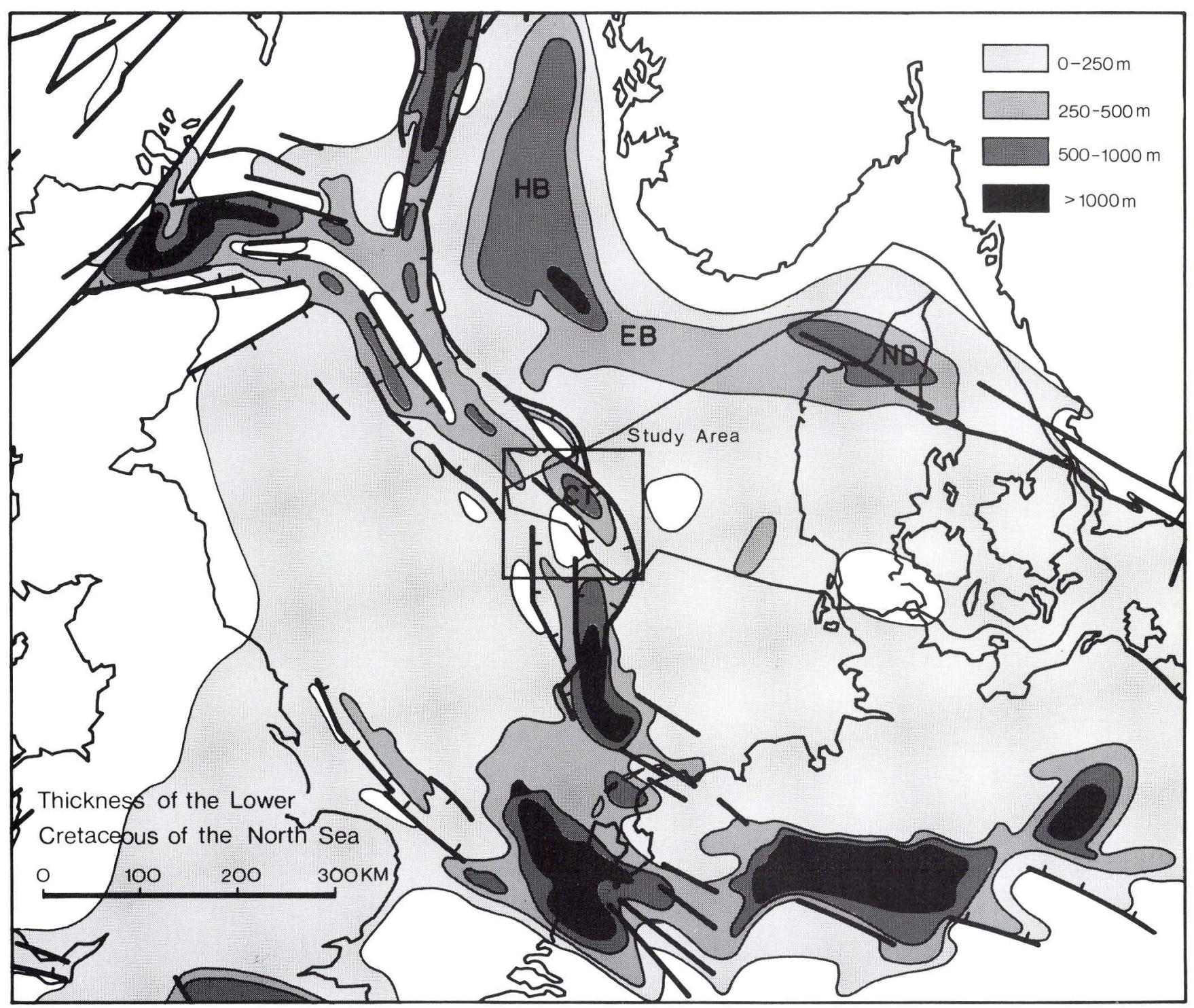

Fig. 1: Generalized extent and thicknesses of Lower Cretaceous deposits (after Ziegler 1982). VG=Viking Graben, HB=Horda Basin, EB=Egersund Basin, ND=Norwegian-Danish Basin, CT=Central Trough. 
upper embrace the Tuxen, Sola and Rødby Formations. This means that the Valhall Formation, - which hitherto has been treated as one unit (e.g. Hesjedal and Hamar 1983, Hancock 1982), or split into two (e.g. Jensen et al. 1986) - has been subdivided into 5 seismically defined units.

In the present paper the tectonic evolution of the structural elements of the Danish Central Graben is described with special emphasis on the Early Cretaceous structural development. Description of the structural and sedimentological evolution of the Lower Cretaceous of the Danish Central Graben is attempted on the basis of the seismic mapping. 
3. Setting

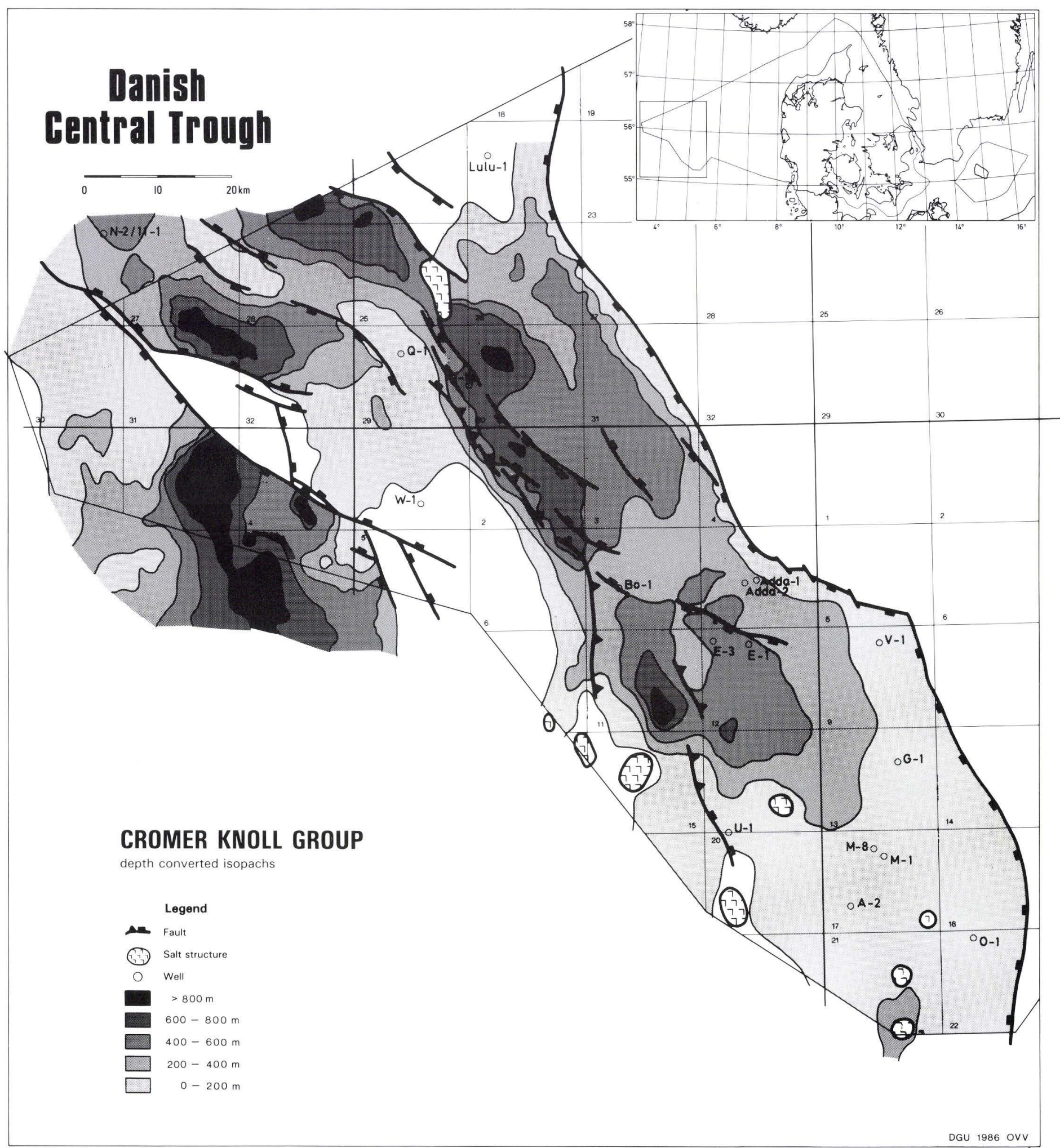

Fig. 2: Generalized isopach map of Lower Cretaceous deposits (the Cromer Knoll Group) in the Danish Central Trough. 
The subsidence of the Lower Cretaceous basins of the North Sea was governed by tectonic patterns very similar to those of the Upper Jurassic (cf. Gowers and Sæbøe 1985, Hancock 1982, Møller in prep.), although with decreasing tectonic activity and decreasing rates of sedimentation (cf. Hansen and Mikkelsen 1983, Holm 1983).

Lower Cretaceous sediments were deposited all over the North Sea, apart from on a few minor structural highs (Ziegler 1982), in an extensional tectonic regime. Depocentres are found in fault controlled basins, generally coinciding with the Upper Jurassic depocentres such as the Viking Graben, the Horda Basin, the Egersund Basin, the Norwegian-Danish Basin and in the Central Trough area (fig. 1). In these basins the Lower Cretaceous sequence attains thicknesses that permit detailed study of the structural development within the sequence. The study area is an example of such a development. The Lower Cretaceous of the Central Trough occurs in several subbasins defined by their local depocentres (fig. 2). These subbasins are the Grensen Nose, the Outer Rough Basin, the Feda Graben, the Gertrud Graben, the Arne-Elin Graben, the Tail End Graben and the Salt Dome Province (fig. 3). These basins are

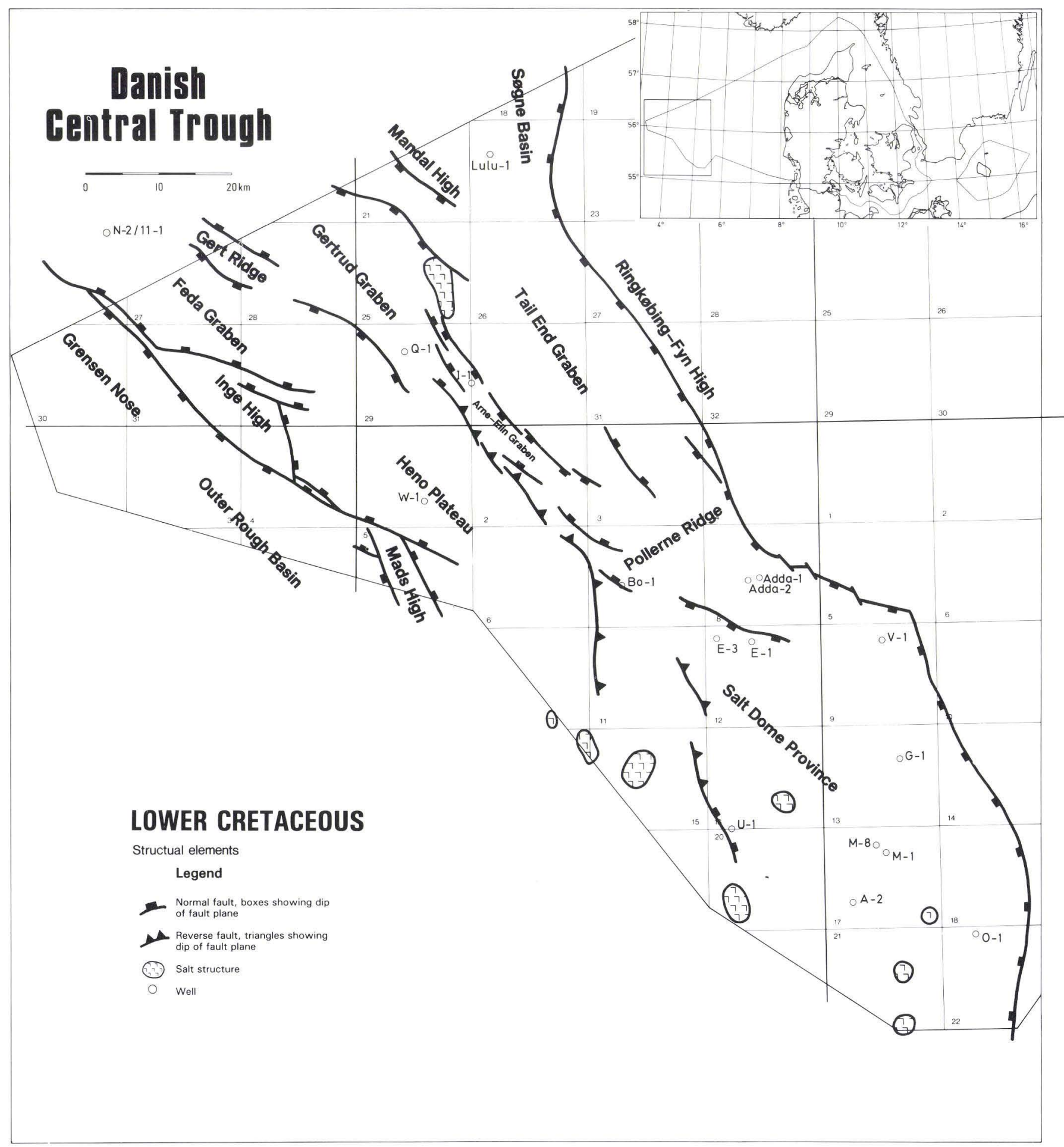

Fig. 3: Major structural elements of the Early Cretaceous in the Danish Central Trough. 
separated and bounded by several structural highs: the Mid North Sea High (west of the Grensen Nose - and Outer Rough Basin), the Inge High, the Mads High, the Heno Plateau, the Gert Ridge, the Pollerne Ridge, the Mandal High and the Ringkøbing-Fyn High (fig. 3 ). Since some of the highs, where the Lower Cretaceous is thin or absent, are associated with shallow marine sands (Michelsen and Andersen 1983, Skjerven et al. 1983), it is likely that some of the highs may have been subaerially exposed. It is believed that parts of the Mid North Sea High, the Inge High, the Mads High, the Mandal High and the Ringkøbing-Fyn High may have been subaerially exposed during most of the Early Cretaceous and have acted as source areas for clastic material. Other highs may have acted as submarine swells that separated different foci of deposition.

\subsection{The Grensen Nose and the Outer Rough Basin}

The Mid North Sea High is a part of the east-west trending Central Highs, which were initiated in Per-

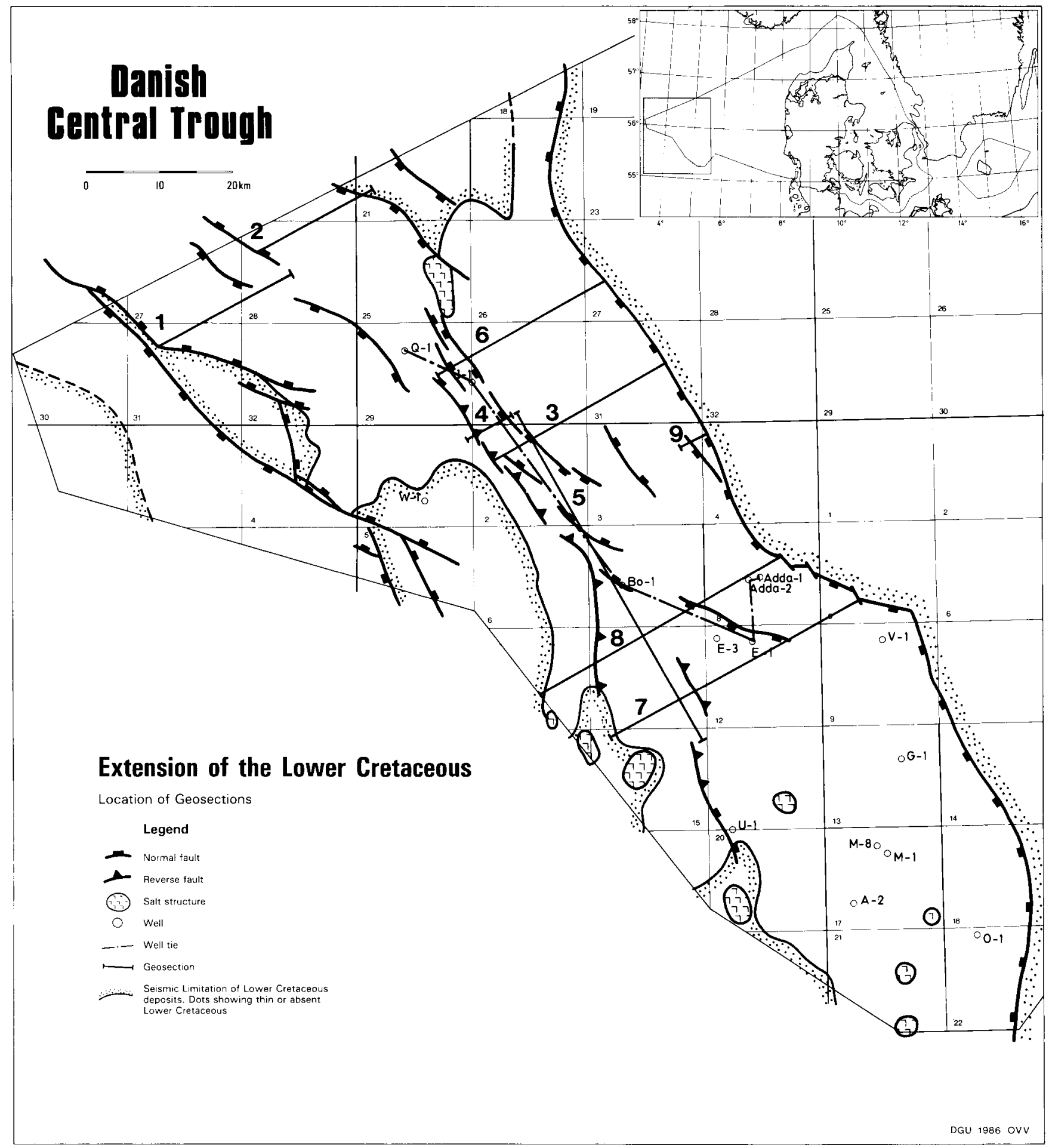

Fig. 4: Extention of Lower Cretaceous deposits. Wells and location of profiles in figs. 5,6,8,13,14,15,16 and 29 are also shown. 
mian times and remained structural highs throughout most of the Mesozoic (Hancock 1982). The highs probably included the Grensen Nose area and the Outer Rough Basin area in Middle Jurassic times (Gowers and Sæbøe 1985) but in the Late Jurassic, the Grensen Nose and the Outer Rough Basin started to subside and thus became a part of the Lower Cretaceous sedimentary basins. The two basins are separated from the other Lower Cretaceous sedimentary basins by the Inge High - Mads High system across which there was little communication. The Lower Cretaceous sequences of the Heno Plateau and the Outer Rough Basin were in limited communication across the Inge High and the Mads High, and the Feda Graben and Grensen Nose likewise had limited communication north of the Inge High.

The lack of possibilities for direct correlation of the seismic sequences and the absence of released well data for well correlation have prevented the interpretation of these basins. They will therefore not be treated further.

\subsection{The Feda Graben}

The Feda Graben (fig. 5) is an asymmetrical NW-SE elongated basin with the thickest sequence lying along the SW boundary fault. The depocentre is located in the Norwegian sector.

The Feda Graben was probably already an important subsiding basin in the Zechstein and it was certainly a subsiding graben of equal importance to the Tail End Graben in the Late Jurassic (Gowers and Sæbøe 1985) (fig. 7). Sedimentation in the Early Cretaceous in this structural unit was governed by the same subsidence patterns as in the Late Jurassic, as is demonstrated by the coinciding depocentres (Møller in prep.). The southeasternmost part of this basin encroaches upon the relatively stable Heno Plateau, but here it has much smaller thicknesses than at the NW end. The basin ceased to exist as a separate basin in the Late Cretaceous, owing to cessation of normal fault activity. Instead, inversion caused the central parts to form a broad NW-SE-elongated dome (fig. 5). Similarly, the southwestern edge of the basin was subjected to reverse faulting resulting in the development of a northwest-southeast trending narrow ridge probably associated with compressional strike-slip movement similar to that which affected the Arne-Elin Graben (see below).

The Feda Graben is separated from the Gertrud Graben to the northeast by a ridge called the Gert Ridge, stretching in a northwesterly direction from the Heno Plateau, across which the upper Lower Cretaceous seismic sequence units are continuous, - only seismic units LCA, LCB and LCC are missing. The Q-1 well is situated on this ridge (fig. 3).

\subsection{The Gertrud Graben}

The Gertrud Graben (fig. 6) was not an area of subsidence before the end of the Jurassic (cf. Gowers and Sæbøe 1985). Like the Feda Graben the basin is a northwest-southeast elongated half-graben but with the depocentre along the northeasterly bounding fault. The depocentre is located in the Danish sector close to the Norwegian sector. The northeasterly bounding fault of this graben is the northwestern continuation of the Arne-Elin Graben fault-system, which was an active wrench fault zone from Late Jurassic to Early Tertiary times. The system was a NNW-SSE-striking, left-lateral transtensional wrench fault-system during the Early Cretaceous which was conjugated to the WNW-ESE striking right lateral wrench fault-system that existed in the Late Jurassic along the Inge High Southern Tail End Graben trend (Gowers and Sæbøe 1985) shown in figs. 7 and 9. However, apparently only the NNW-SSEstriking part of this conjugated fault-system was active in the Early Cretaceous, and gave rise to the Arne-Elin Graben system and the fault activity along the northeasterly bounding fault of the Gertrud Graben.

The left-lateral motion along the Arne-Elin Graben fault-system is thought to have given rise to normal faulting along the northeastern fault of the Gertrud Graben in accordance with the assumed left lateral stress field (figs. 9 and 10). In the Late Cretaceous Early Tertiary the Gertrud Graben was subjected to inversion, expressed as reverse faulting along the northeasterly boundary fault (fig. 6). Unlike in the Feda Graben the inversion did not result in warping of the basin.

\subsection{The Arne-Elin Graben}

The Arne-Elin Graben is a NNW-SSE striking narrow graben system (fig. 8). The Arne-Elin Graben was not an individual structural element before the Late Jurassic (Møller in prep.), but was merely a westerly continuation of the Tail End Graben. In the late Late Jurassic the development of a transtensional (or negative) flower structure (cf. Harding 1985) (caused by the above mentioned wrench faulting) gave rise to this minor graben structure. Comparison of the thicknesses of seismic units in the Arne-Elin Graben and in the Tail End Graben suggests that the graben faulting began in the Late Oxfordian (Møller in prep.). The present ap-

Fig. 5: Time section 1 across the Feda Graben. The central part has been upwarped owing to Late Cretaceous - Early Tertiary inversion, but the saucer shape of the Lower Cretaceous basin floor may still be seen. The shape of the Lower Cretaceous basin floor is thought to be the result of both some faulting and of compaction of the thick underlying Upper Jurassic sequence (more than $1 \mathrm{~km}$ according to Gowers and Sabøe 1985). For location see fig. 4. 

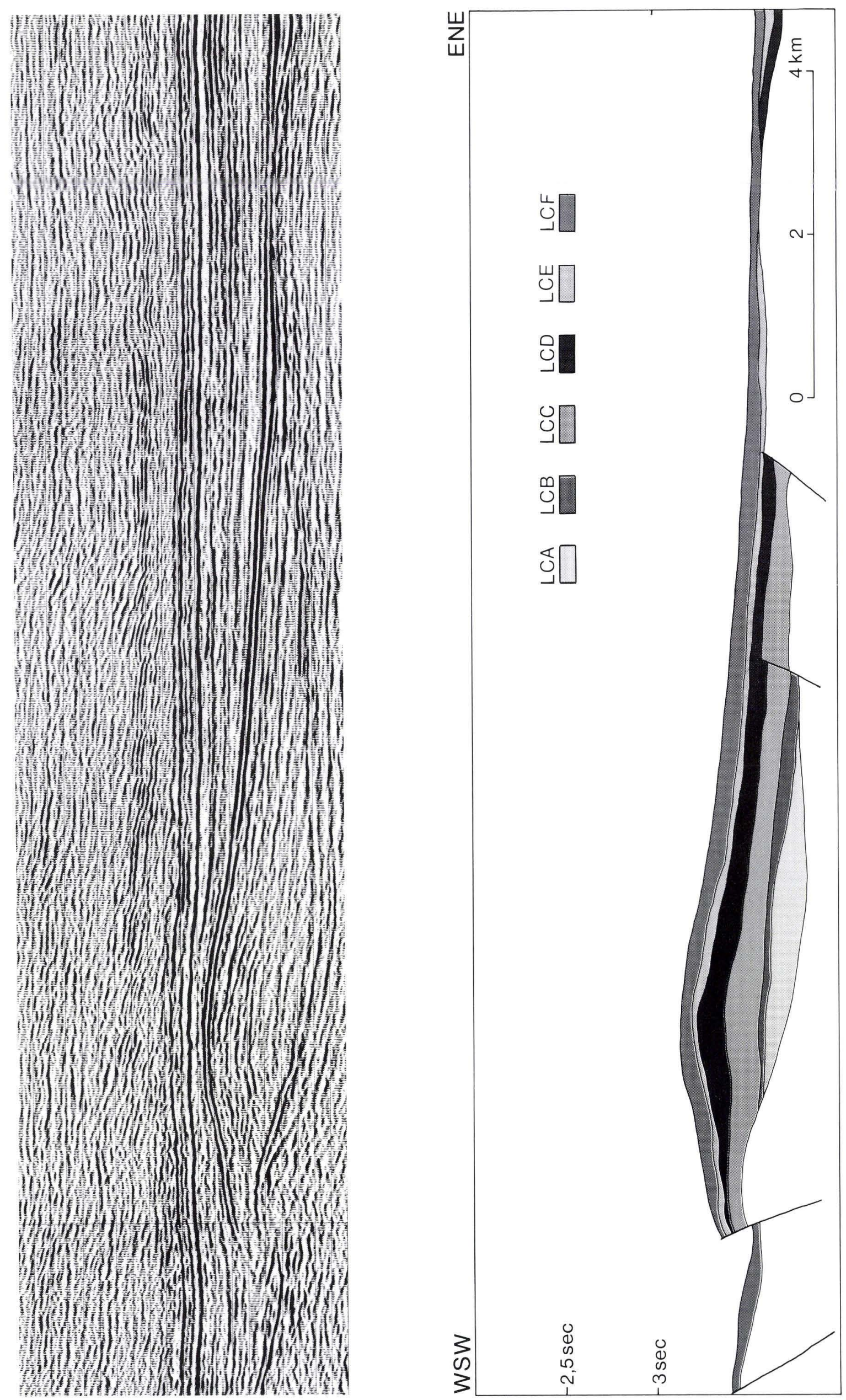

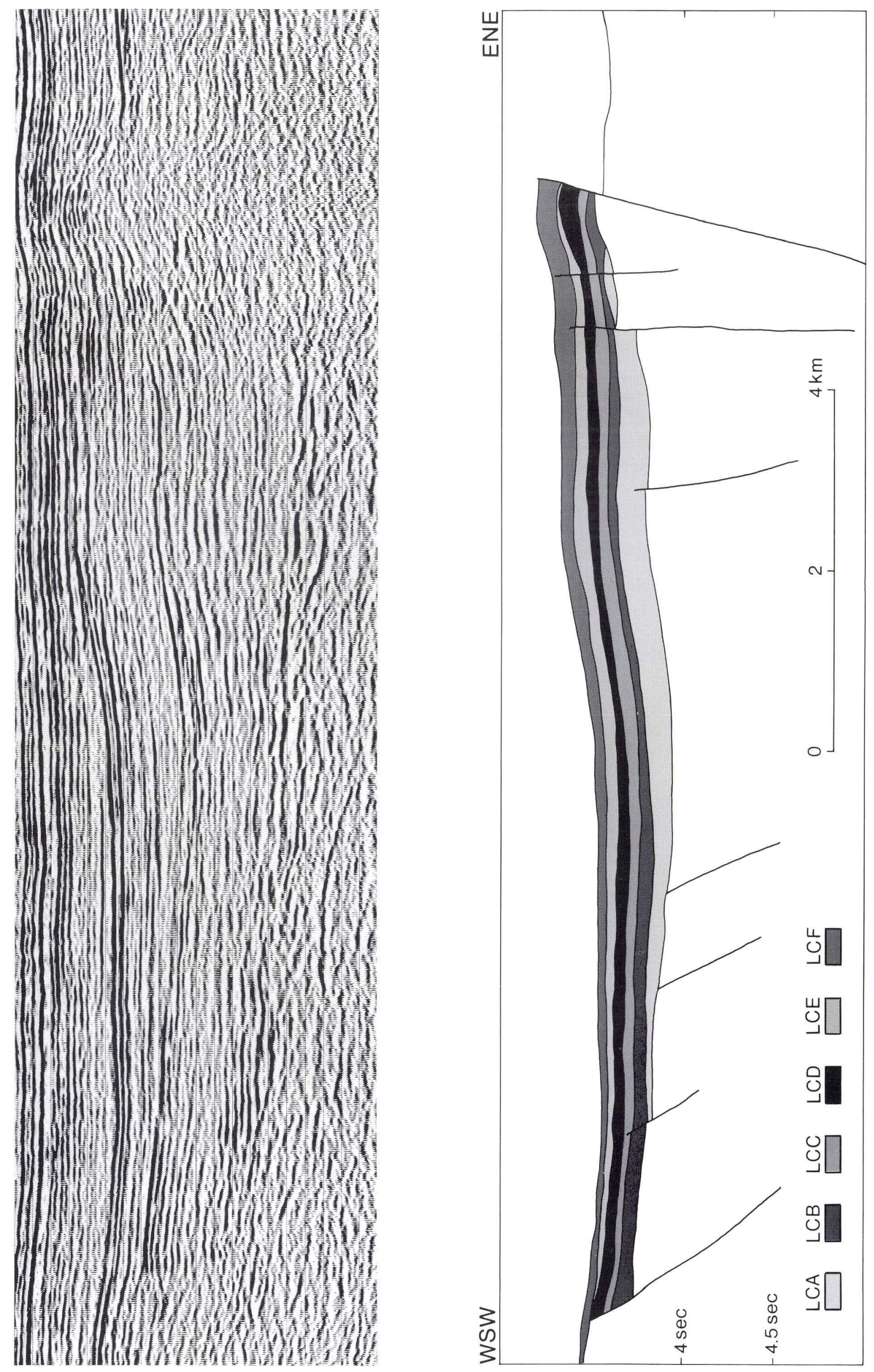
pearance of the graben is, however, greatly influenced by Late Cretaceous - Early Tertiary inversion, which caused the graben to dome up into a positive flower structure under the influence of compressional strikeslip (cf. Andersen et al. 1982, Michelsen and Andersen 1983 and fig. 11). As in Late Jurassic times (Gowers and Sæbøe 1985), the system is here believed to have been governed by transtensional wrenching in the Early Cretaceous. This activity was responsible for the development of conspicuous local depocentres characterized by lateral shifts and rapid sedimentation (compared to adjacent areas), which is characteristic of wrench-induced subsidence patterns (cf. Reading 1980). The graben system is terminated to the north by the Arne salt structure (just north of the Q-1 well) and to the south by the Bo structure (at the Bo-1 well). The northern continuation of the wrench system is the fault along the northeastern side of the Gertrud Graben, as described above. In the south the wrench system is continued along a north-south-striking, mildly reversed fault which stretches southwards from the Bo-1 well (figs. 3 and 16).

\subsection{The Tail End Graben}

The Tail End Graben has been active since Permian times (Gowers and Sæbøe 1985), but main subsidence took place in the Late Jurassic, when more than $3 \mathrm{~km}$ of sediments accumulated (cf. Kock et al. 1982, Møller in prep.).

During the Jurassic period the Tail End Graben was a southern continuation of the Søgne Basin in the Norwegian sector and extended into the Salt Dome Province to the south (Gowers and Sxbøe 1985). In the Early Cretaceous, communication between the Søgne Basin and the Tail End Graben ceased. Meanwhile the southern part of the Tail End Graben became separated from the northern and middle parts and coalesced with the Salt Dome Province to form a single subbasin, owing to the development of a shallow ridge (cf. figs. 2 , 3 and 13) called the Pollerne Ridge. Only limited connection existed between the northern Tail End Graben and the new southern basin while the Søgne Basin became totally disconnected from the Tail End Graben. These transverse uplifted shallow ridges were probably a result of a small rotation of the stress field responsible for the WNW-ESE-striking wrench system which therefore became inactive. Minor compression resulted in the upwarping of these zones.

Fig. 6: Time section 2 across the Gertrud Graben. This basin has responded more elastically to inversion than the Feda Graben, and has survived inversion with little deformation. Late Cretaceous- Early Tertiary inversion is seen as a reverse component of about $350 \mathrm{msec}$ on the easterly bounding fault. For location see fig. 4.

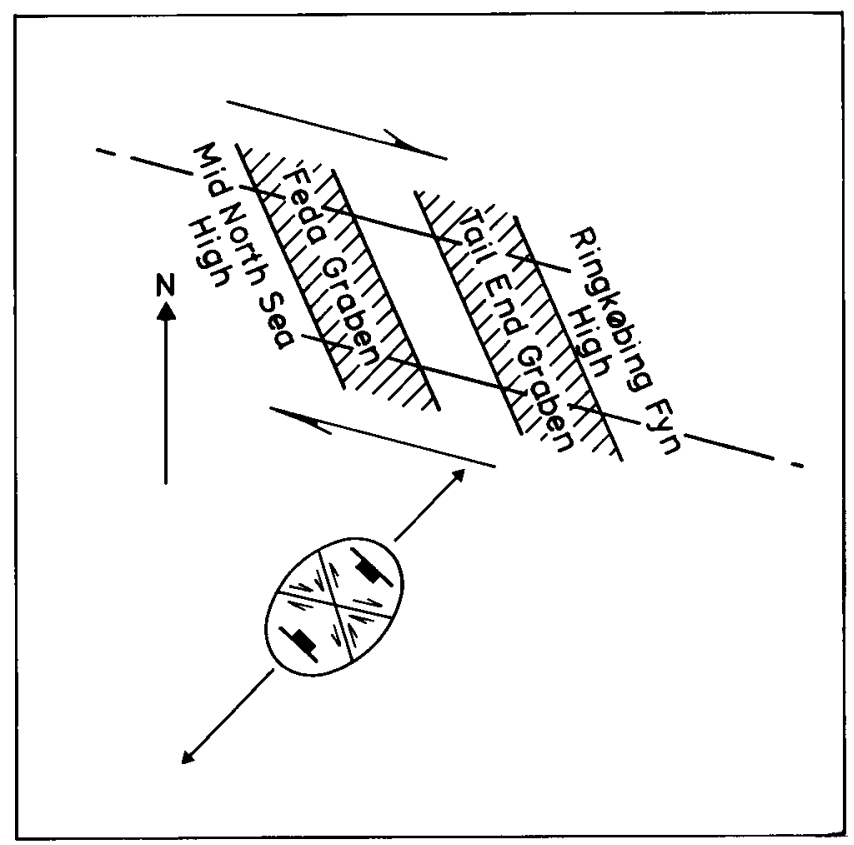

Fig. 7: Major faults responsible for the Late Jurassic development of the Feda Graben and Tail End Graben are illustrated diagrammatically (after Gowers and Sabøe, 1985).

Previously the Tail End Graben was governed by extensional and rotational block-faulting, which to some extent continued. The central part, however, became mildly upwarped, along a NNW-SSE axis in the centre of the graben, in Jurassic - Cretaceous boundary times. The structure and fault pattern within this ridge have the characteristics of a compressional (positive) flower structure (fig. 14, cf. Harding 1985). The fault- system can be followed northwestwards into the southwesterly bounding fault of the Mandal High (P. Japsen, pers. comm. 1985). To the southeast the fault seems to loose importance and die out. The system is parallel to the Arne-Elin Graben fault-system and a left lateral wrench motion is also confirmed by offset of east-west striking faults in the Jurassic sequence (Møller in prep.). In contrast to the Arne-Elin Graben fault- system, this system is more dominated by compression, leading to the development of a NNW-SSE striking ridge onto which the Lower Cretaceous units onlap (fig. 14). This curiously local compressional flower structure, which dies out to the north and to the south, is believed to be caused by right stepping of left lateral wrenching along the Arne-Elin Graben fault-system and the Mandal High southwest bounding fault. Rightstepping of a left lateral wrench system causes local compression (fig. 12). This situation is believed to have occurred in the latest Jurassic, possibly also in the beginning of the Early Cretaceous.

\subsection{The Salt Dome Province}

The Salt Dome Province has been an area of continued 

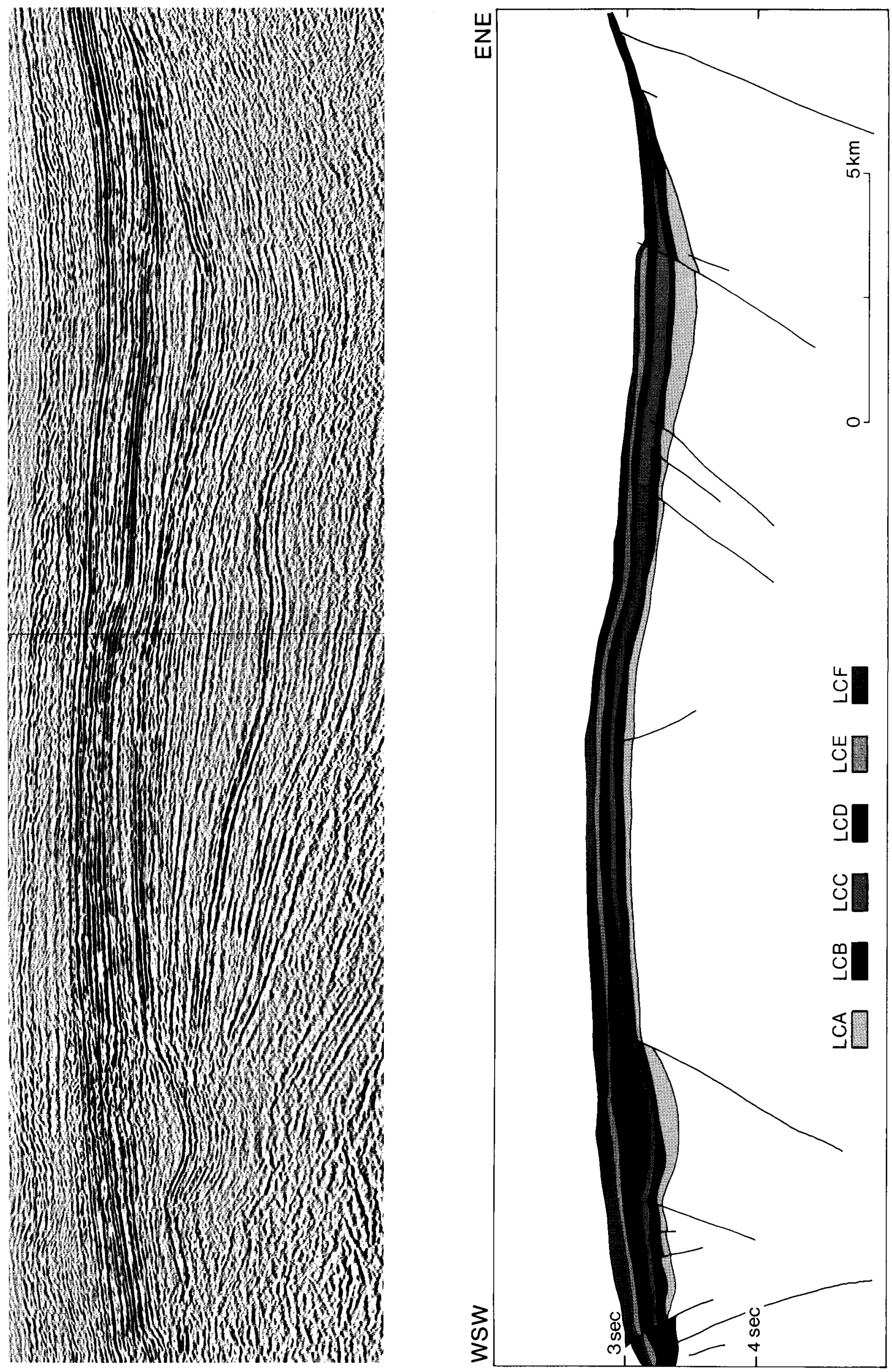


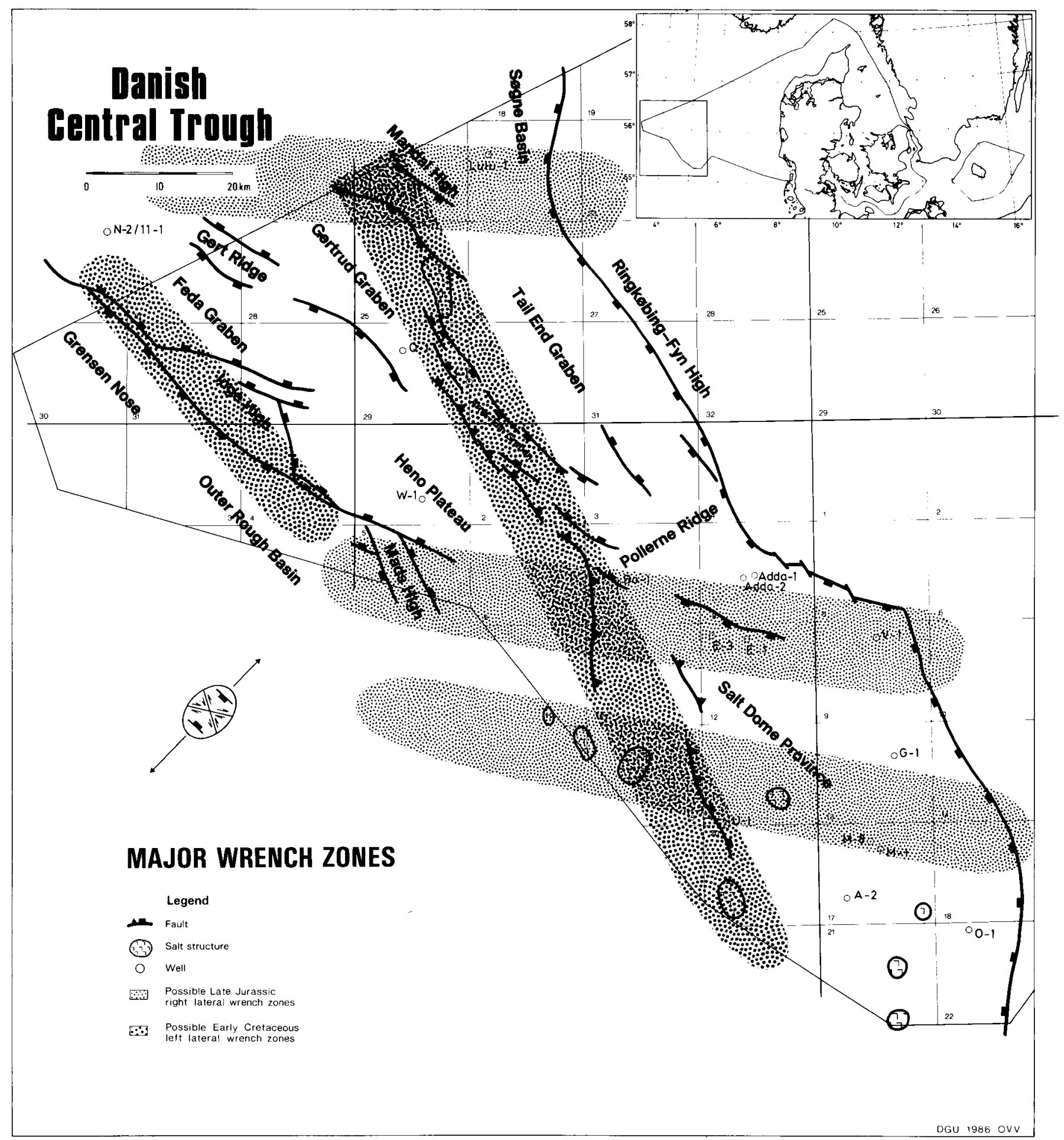

Fig. 9: The major wrench zones governing basin development in the Late Jurassic and Early Cretaceous. The WNW-ESE component (after Gowers and Sabøe 1985) cannot be shown to have been active during the Late Cretaceous, whereas the conjugated NNW-SSE direction was evidently active in both periods.

subsidence since the Permian and was an area of active subsidence at the end of the Jurassic (Koch et al. 1982), but of less importance than the Tail End Graben and Feda Graben. In the Early Cretaceous, the southern part of the Tail End Graben became partly separated

Fig. 8: Time section 3 across the southern Tail End Graben. Note Late Cretaceous - Early Tertiary inversion of the ArneElin Graben, seen to the left. For location see fig. 4. from the middle and northern part of the graben (cf. Michelsen and Andersen 1983), and coalesced with the Salt Dome Province as a single basin owing to the development of the Pollerne Ridge as discussed above. This new basin will nevertheless be referred to as the Salt Dome Province in this paper. The very conspicuous depocentre of this new basin is located in the northern part of the Salt Dome Province (figs. 2, 15). The depocentre is located in the southern continuation 


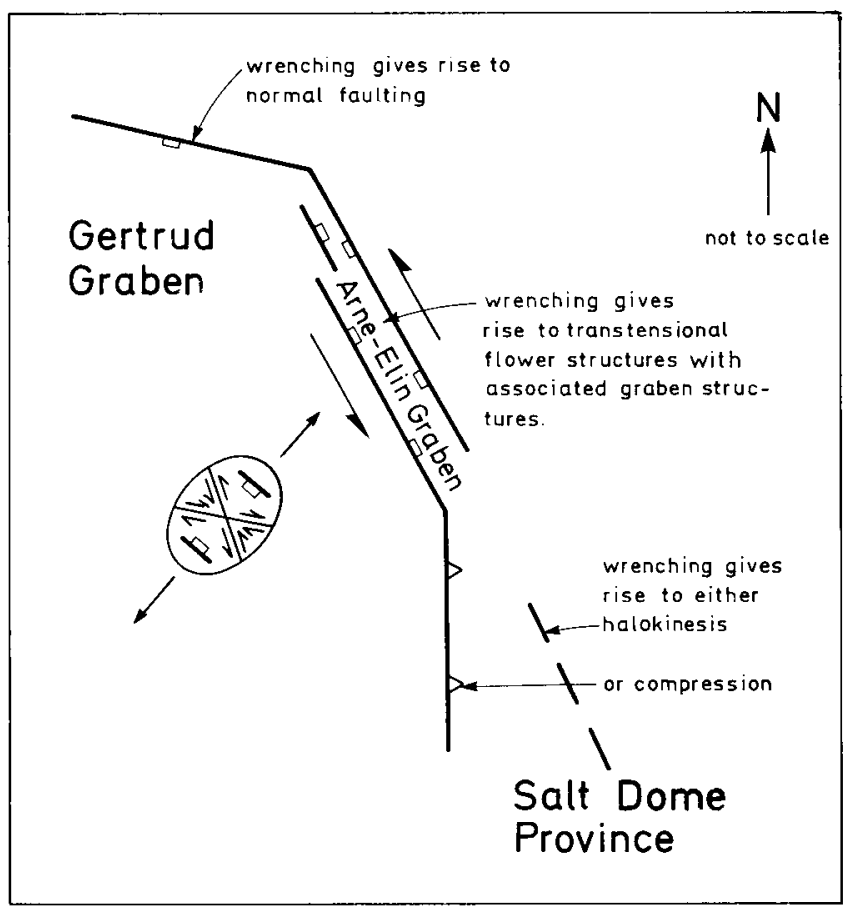

Fig. 10: The wrench zone in the centre of the Danish Central Trough is here scematically illustrated. A left lateral motion along this fault-system clearly results in normal faulting along the northern part and compression may occur in the western part to the south. It is, however, believed that some wrench fault movement has been assimilated in basement faults in the centre of the Salt Dome Province, thus enhancing halokinesis and giving rise to the depocentre south of the Bo-1 well (fig. 2).

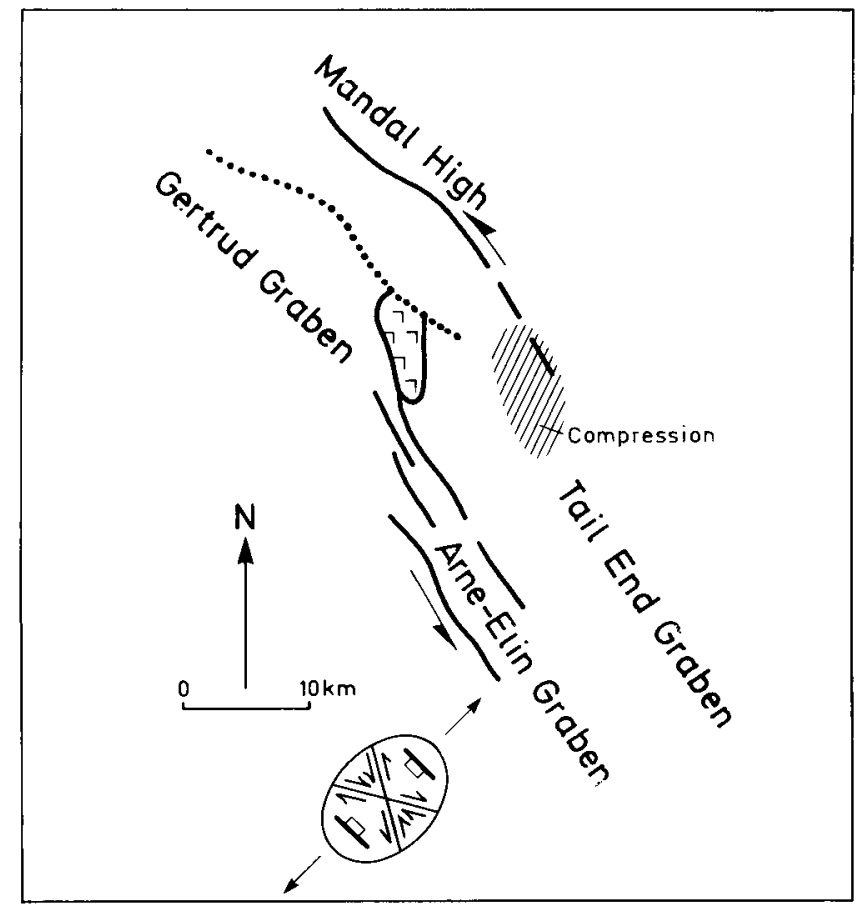

Fig. 12: This schematic illustration may explain the local compressional flower structure found in the northern part of the Tail End Graben. Local compression is believed to have been caused by right stepping of left lateral wrenching in Jurassic Cretaceous boundary times. The north-east bounding fault of the Gertrud Graben (dotted) is not active in this context.
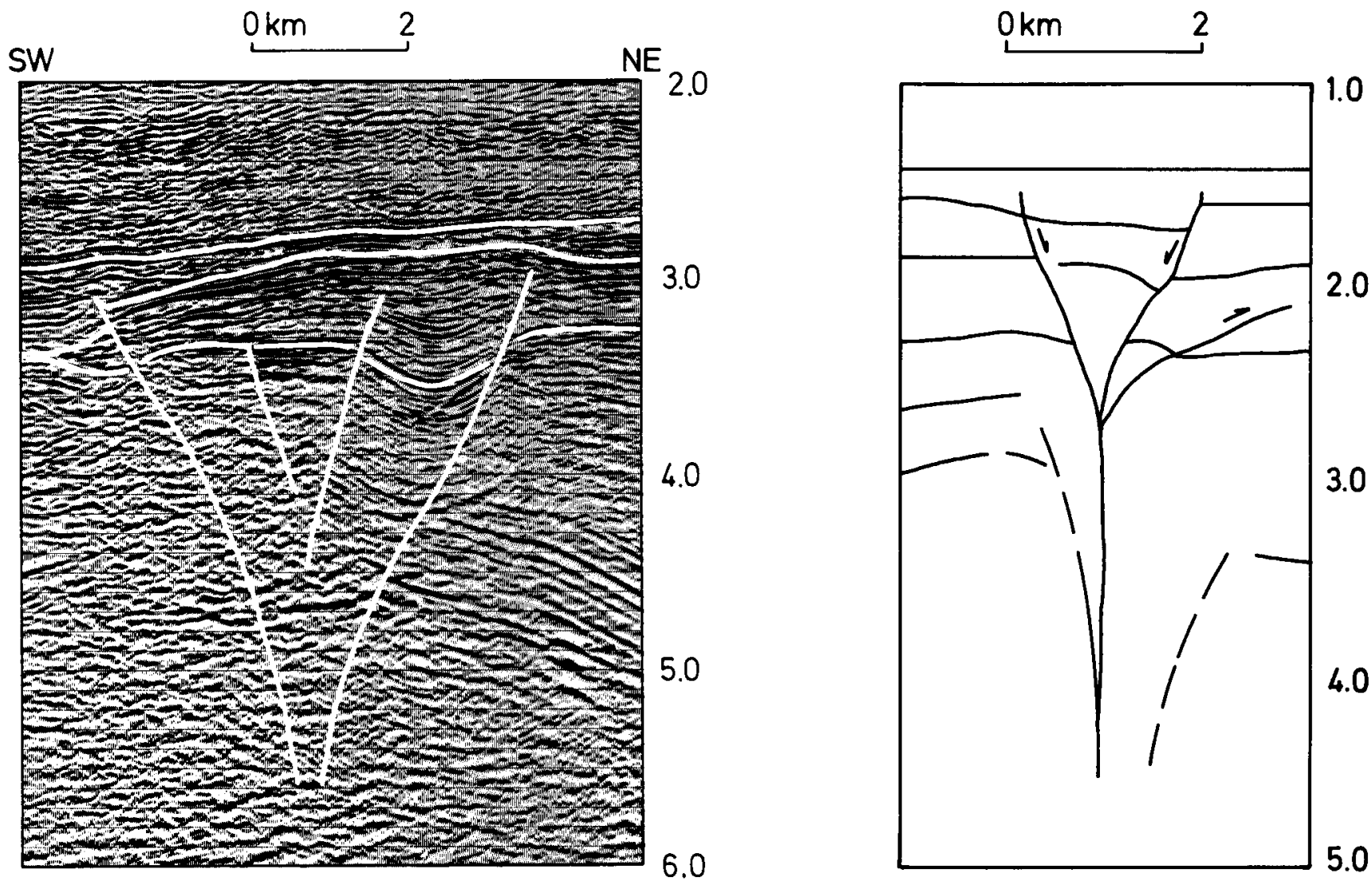

Fig. 11: This section 4 through the Arne-Elin Graben (to the left) is interpreted as a compressional (positive) flower structure. However, the conspicuous thickening of the Lower Cretaceous in the graben indicates an initial period of extension and subsidence. It is believed that the graben developed as a transtensional (negative) flower-structure during this period similar to the one seen on the right (after Harding 1985). The difference in size is thought to relate to the thickness of sediment cover. For location see fig. 4. 


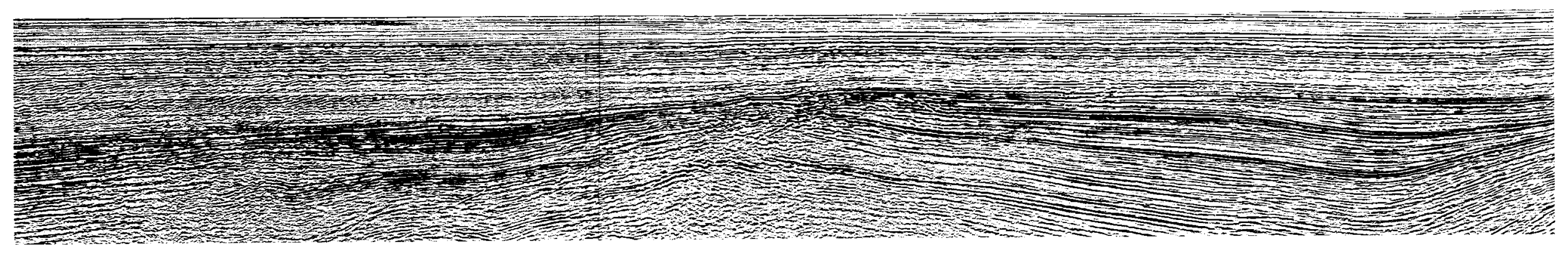

NNW

\section{$\square^{\text {LCA }}$ LCC LCD LCE LCF}

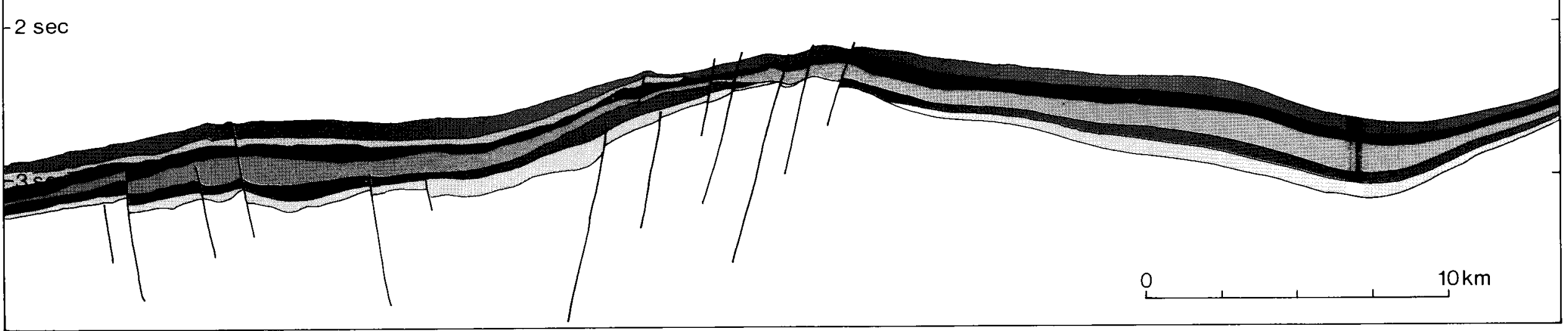

Fig. 13: Time section 5 across the Pollerne Ridge (close to the Bo-l well) that separated the Tail End Graben and the Salt Dome Province in the Early Cretaceous. For location see fig. 


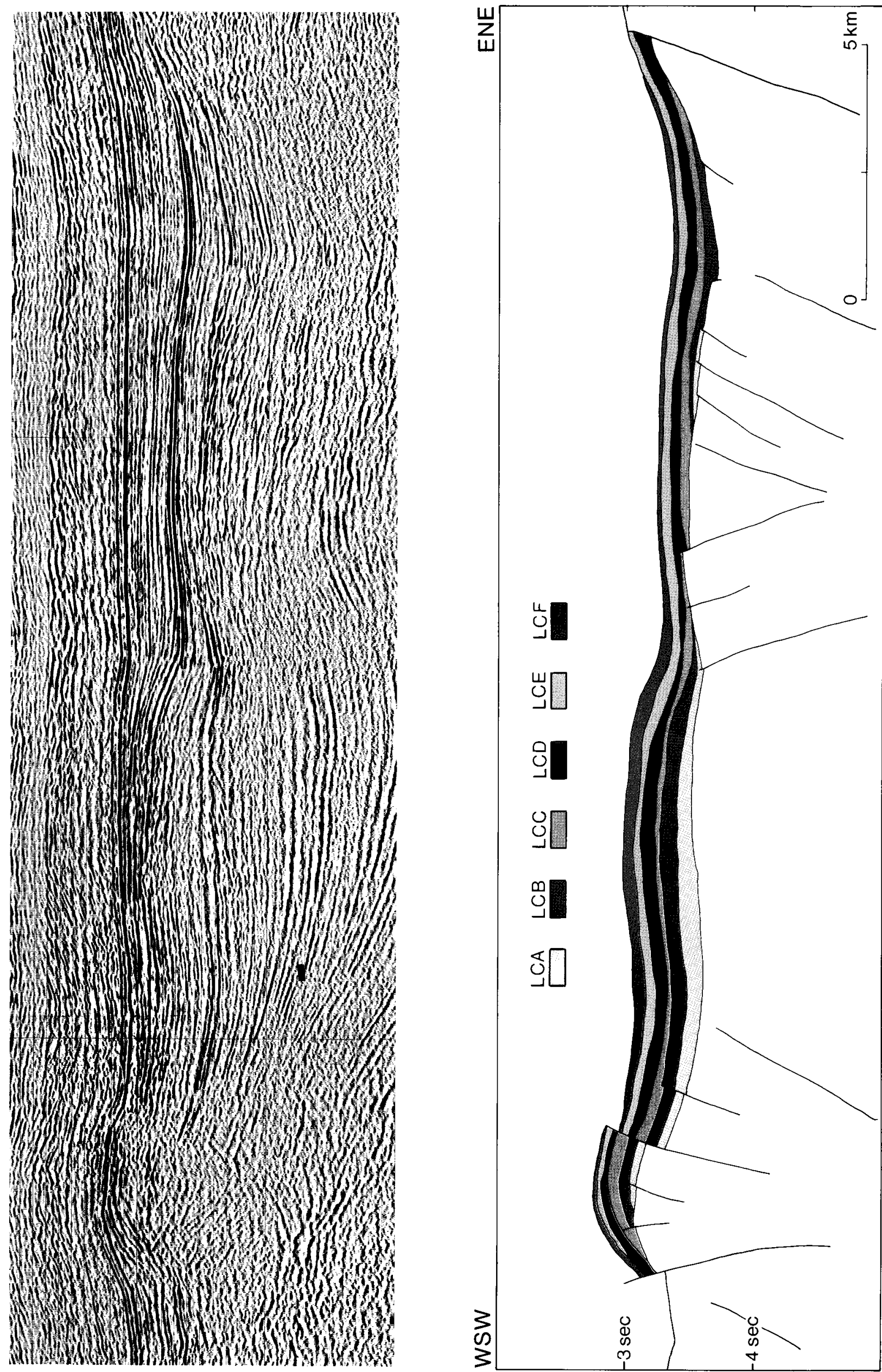


Fig. 15: Time section 7 across the Salt Dome Province. This section crosses one of the most pronounced depocentres of the Lower Cretaceous. "The subsidence of the depocentre is thought to have been caused by a combination of wrenching and salt flow. For location see fig. $4 . \downarrow$
Fig. 14: Time section 6 across the northern Tail End Graben. Note the compressive flower structure through the central part of the Tail End Graben. The Arne-Elin Graben has been inverted conspicuously in Late Cretaceous - Early Tertiary times. For location see fig. 4
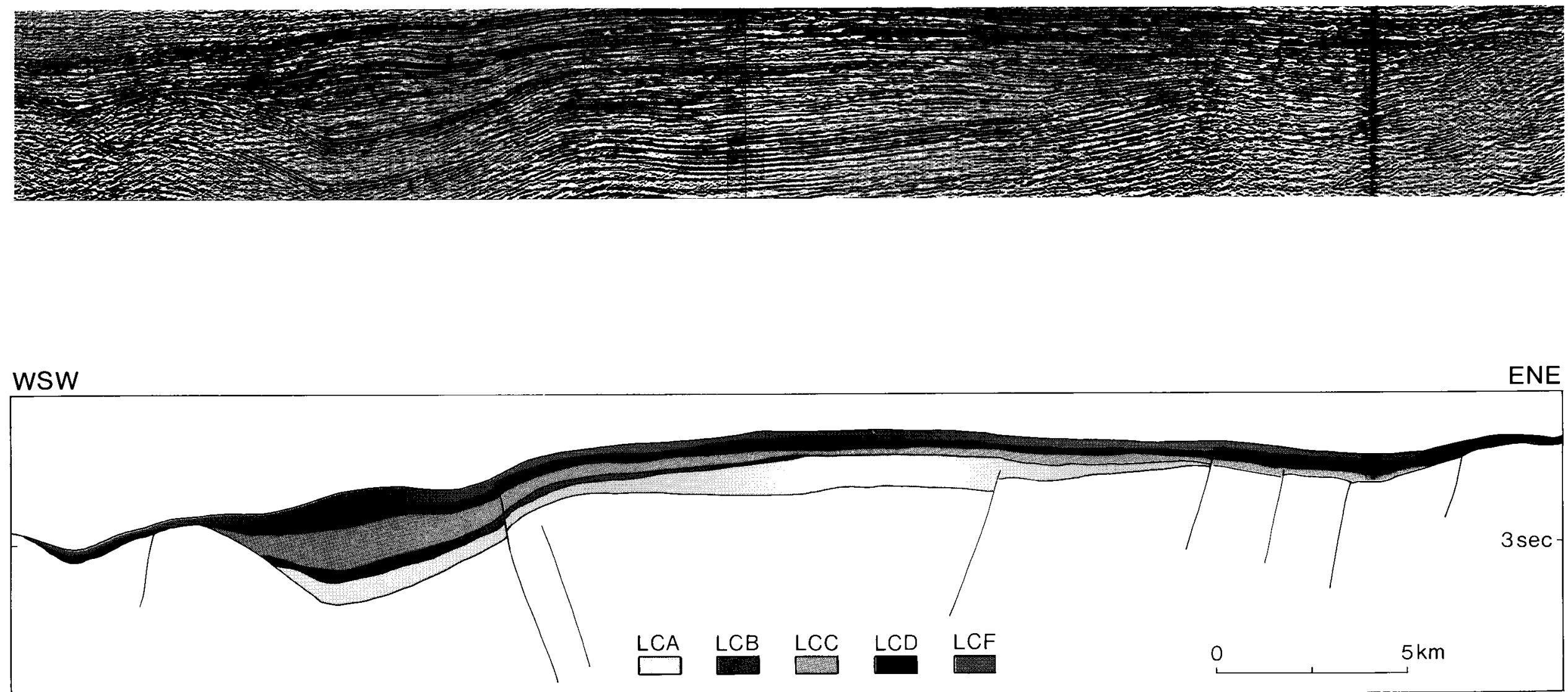


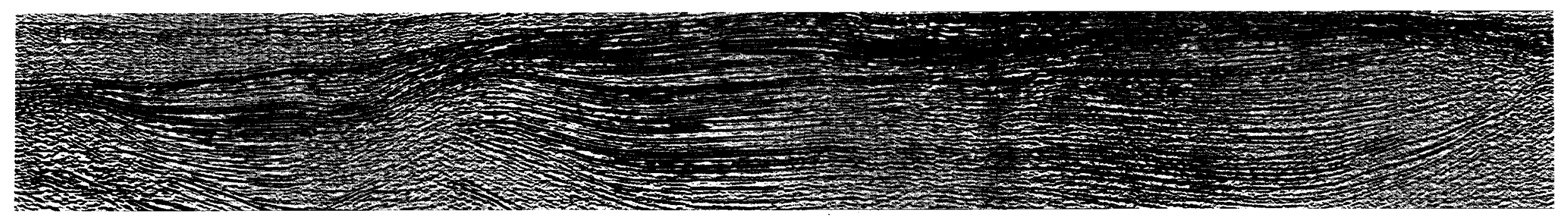

WSW

ENE

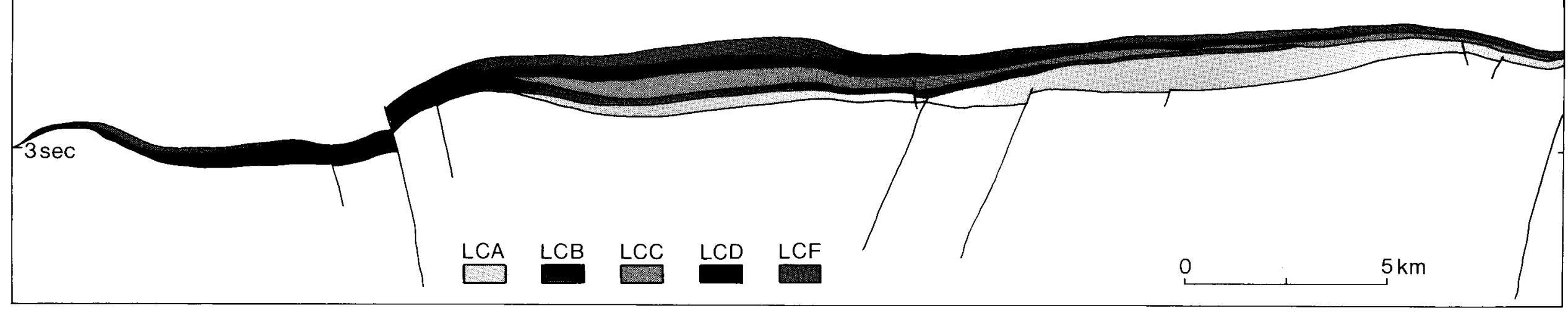


of the Arne-Elin Graben fault-system, but with far less conspicuous correlation between wrench faults and depocentres, owing to the halokinetic overprint. Halokinesis becomes more important to the south as the Lower Cretaceous sequence becomes thinner, and piercement of salt structures occurs along the border to the German sector. The northern part of this basin is terminated to the west along a conspicuous N-S striking reverse fault (fig. 16) that probably originally was a normal fault influenced by reverse faulting in the Early Cretaceous. In accordance with a left lateral motion along the Arne-Elin Graben fault-system local com- pression arose along this fault (fig. 10) in the Early Cretaceous. During the Jurassic the fault may have been a normal fault (Møller in prep.), but in the Late Cretaceous the fault received the main reverse component, thus becoming a true reverse fault in the Late Cretaceous (fig. 16, cf. Andersen et al. 1982, Hansen and Buch 1982). It is also believed that some wrench movement was taken up by a more southeasterly fault, which triggered or enhanced halokinesis (fig. 10, Andersen et al. 1982). The basin continues to the south where thicknesses again increase in the German and Dutch sectors of the North Sea.

Fig. 16: Time section 8 across the northern Salt Dome Province. For location see fig. 4. 


\section{Seismic subdivision of the Lower Cretaceous}

The boundaries of the studied sequence were selected with the aid of well ties (fig. 17 and table 1). The sequence comprises the Valhall Formation, the Tuxen Formation, the Sola Formation, the Rødby Formation and the Vyl Formation (fig. 18, Jensen et al. 1986). These formations consist of sediments ranging in age from Ryazanian to Albian. The sediments are composed of marlstone and calcareous claystone with subordinate limestone stringers and sand and siltstone. The sand and silt occurrences tend to be found at the base of the sequence, while the carbonate content is greatest at the top (cf. Jensen et al. 1986). The reflector at the base of the studied sequence, called the TJ reflector (figs. 17 and 18), is thought to be equivalent to the base of the Valhall Formation (cf. Jensen et al. 1986, Heilmann-Clausen in prep.). The lithological boundary is characterized by an abrupt change in lithology from black bituminous shales of the Farsund Formation to light calcareous clays and marls of the Valhall Formation. This results in a relatively strong impedance contrast, which renders the reflector of high amplitude and continuous (formerly considered a regional unconformity and named the Late Cimmerian Unconformity). The lithological change is thought to be due to a relative rise in sea level bringing about more oxygenated conditions (Rawson and Riley 1982). The TJ reflector is mainly concordant to, or shows a toplap relation to internal reflectors immediately below (e.g. fig. 20). Simple truncation is more rare and mainly coinciding with areas where the Lower Cretaceous is also truncated (fig. 21). Biostratigraphic datings across the lithological boundary suggest sedimentation to be continuous across the Jurassic - Lower Cretaceous boundary (e.g. Birkelund et al. 1983, Heilmann-Clausen in prep.) in and around the Lower Cretaceous depo- centres. The Late Cimmerian faulting is therefore not believed to have caused a major erosional unconformity, except in limited areas that were also structural highs at the end of the Late Jurassic.

The upper boundary of the studied sequence is called the $\mathrm{BK}$ reflector, which is believed to be equivalent to the base of the Chalk Group. The boundary is characterized by slight truncation of the Lower Cretaceous and by conspicuous onlap of the chalk sequence onto the inverted Lower Cretaceous substratum.

The seismic sequence boundaries were chosen according to criteria of stratigraphic significance. Sufficient significance is assumed, if a discontinuity expressed by toplap, onlap, downlap or truncation can be discerned and traced throughout the basin. Two levels within the Lower Cretaceous sequence have proved to correlate with log motifs. The lower one is the base of unit LCC, which correlates with the so called marker "A" (fig. 18, Jensen et al. 1986). The other one is at the base of unit LCF which correlates with the base of the

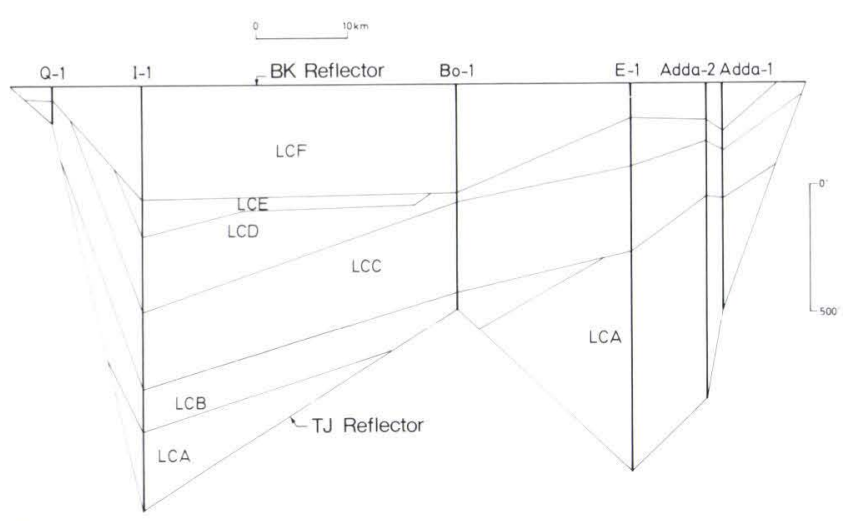

Fig. 17: Well-tie of the seismic units. See fig. 4 for location.

\begin{tabular}{|c|c|c|c|c|c|c|c|c|c|c|c|c|}
\hline \multirow[t]{2}{*}{ Well } & \multicolumn{2}{|c|}{ Base Chalk Group } & \multicolumn{2}{|c|}{ Base LCF } & \multicolumn{2}{|c|}{ Top LCC } & \multicolumn{2}{|c|}{ Top LCB } & \multicolumn{2}{|c|}{ Top LCA } & \multicolumn{2}{|c|}{ Top Jurassic } \\
\hline & Depth & TWT & Depth & TWT & Depth & TWT & Depth & TWT & Depth & TWT & Depth & TWT \\
\hline ADDA-1 & 7512 & 2161 & 7700 & 2210 & 7777 & 2230 & 7965 & 2280 & 7965 & 2280 & 8400 & 2390 \\
\hline ADDA-2 & 7707 & 2189 & 7854 & 2225 & 7935 & 2245 & 8195 & 2312 & 8195 & 2312 & 8950 & 2500 \\
\hline E-1 & 8162 & 2214 & 8296 & 2233 & 8488 & 2290 & 8820 & 2368 & 8820 & 2368 & 9730 & 2570 \\
\hline BO-1 & 7468 & 2162 & 7896 & 2249 & 7930 & 2275 & 8287 & 2360 & - & - & 8350 & 2375 \\
\hline $\mathrm{I}-1$ & 9355 & 2730 & 9798 & 2820 & 10240 & 2910 & 10550 & 2978 & 10710 & 3016 & 11018 & 3068 \\
\hline Q-1 & 13000 & 3328 & 13050 & 3335 & - & - & - & - & - & - & 13140 & 3425 \\
\hline
\end{tabular}

Table 1: Well-tie of sequence boundaries is here listed in feet below reference level and two-way time (msec. below mean sea level). The error arising from seismic resolution may amount to 80 feet. Similarly, an apparant pinch-out may represent thicknesses of less than 80 feet. 


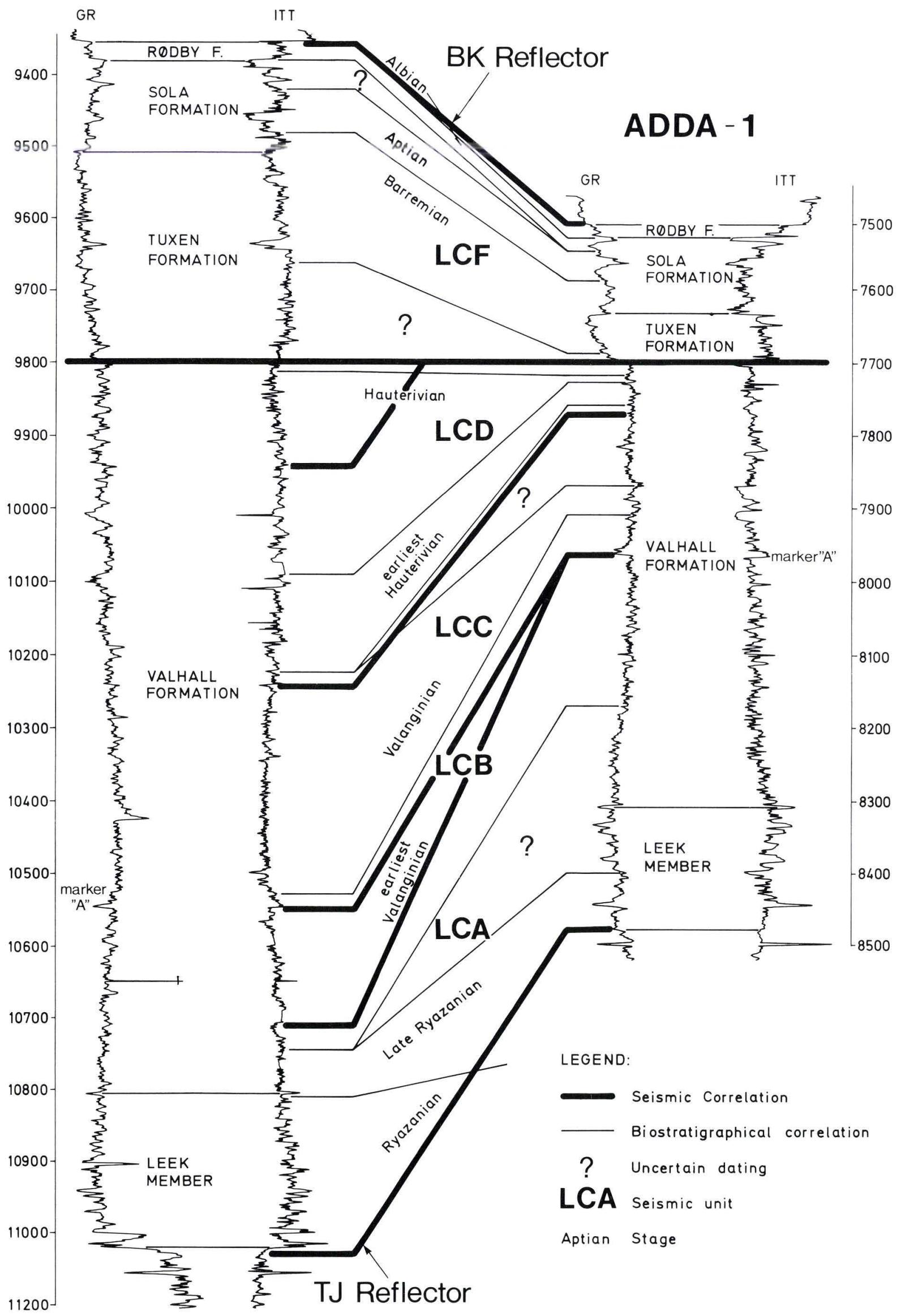

Fig. 18: The wells Adda-1 and I-1 are shown with lithostratigraphy, seismic units and biostratigraphy. The log defined marker " $A$ " is also indicated. The apparent diachronous nature of the basal Valhall reflector may be explained by reworked fossils. See fig. 4 for location. Modified from Heilmann-Clausen, (in prep.). 
Tuxen Formation of Jensen et al. (1986), and is characterized by an upward increase in interval velocity. These two levels have made control of the seismic correlation possible. The interpreted structural and sedimentological evolution of the Early Cretaceous as below outlined is mainly supported by description of isopach maps. The depth maps convey mainly the effects of the Late Cretaceous and Early Tertiary inversion events, and the post Early Cretaceous subsidence and is therefore of little use in this work.

The following description of the units is followed by simplified maps showing extension and thickness variations of the units. Further details can be obtained from the enclosed maps (encl. 1-11). It is very important to note that the lithological units with which they may correlate may extend much further if thicknesses

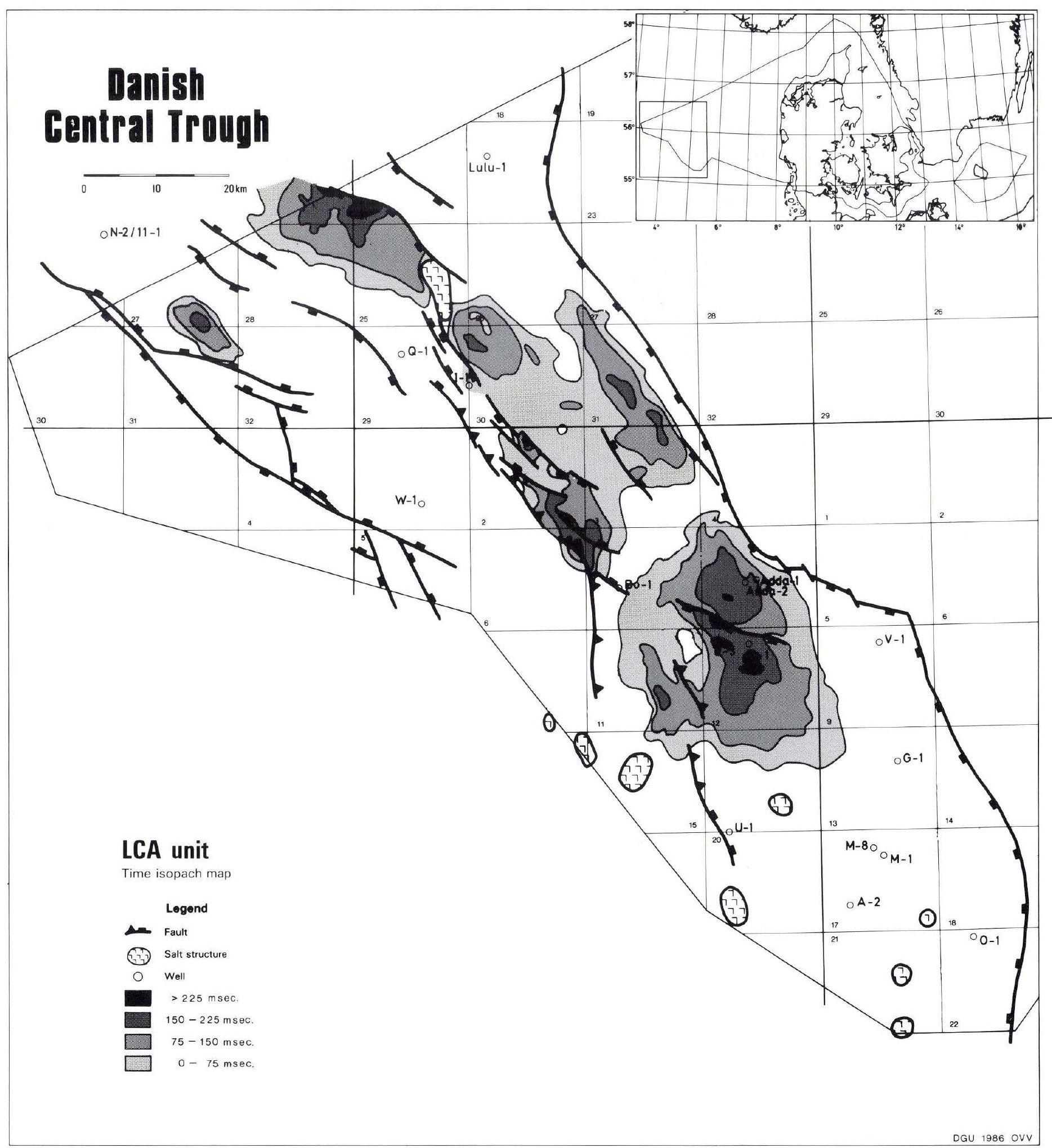

Fig. 19: Seismic extent of unit LCA, expressed by TWT isopachs for the unit. See enclosure 6 for greater detail. 


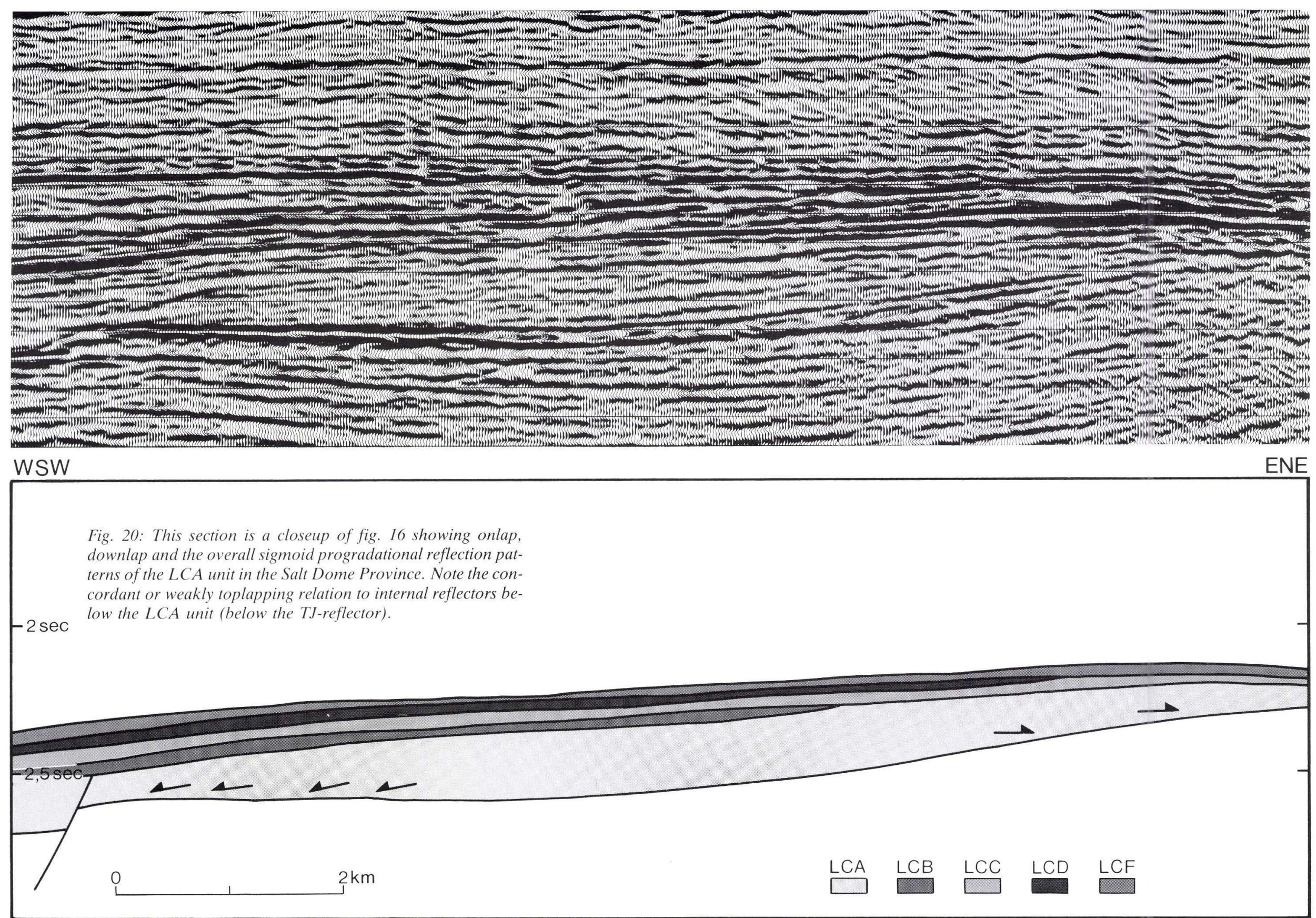

Dis section is a closeup of fig. 16 showing onlap, cordant or weakly toplapping relation to internal reflectors be 2.

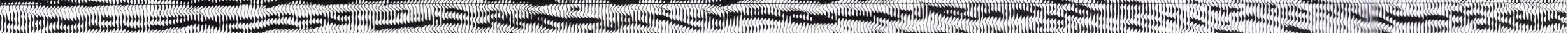
Tht a

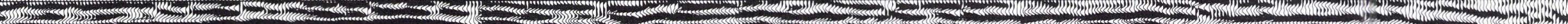
(1) (1)

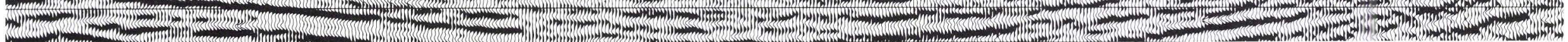
WSW 


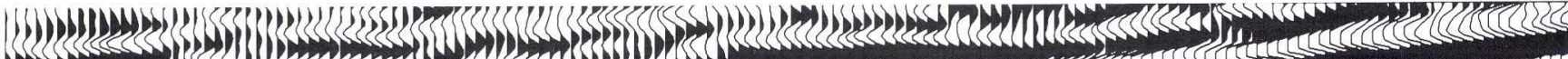

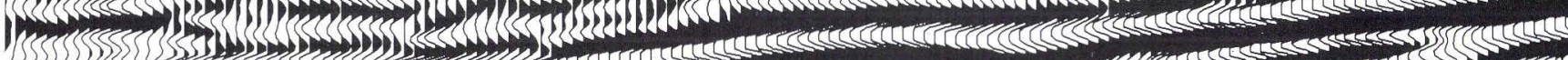

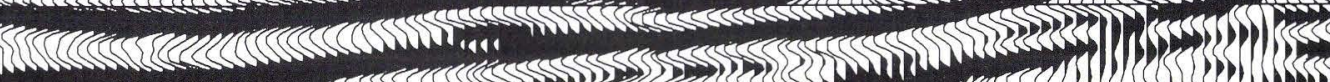
ISTh

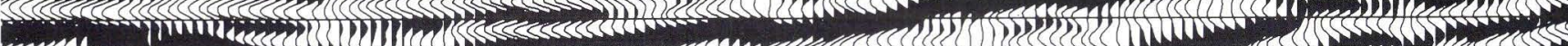

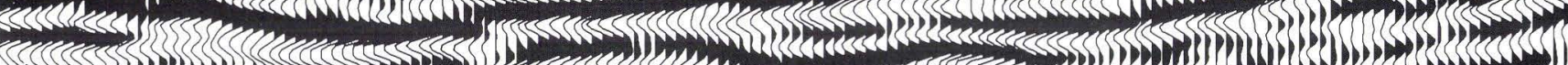

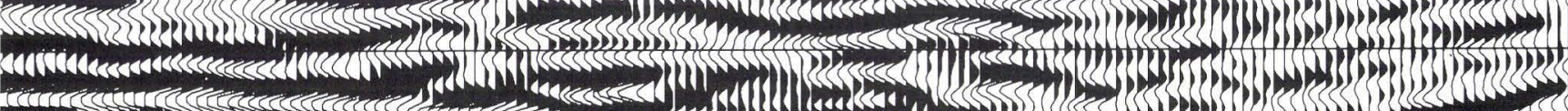
res . 1) 3.

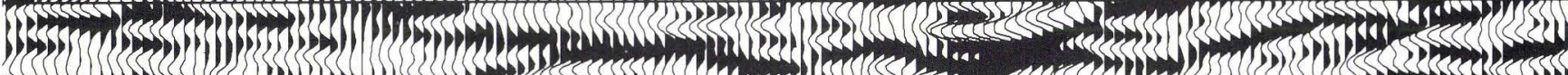
SW. - 51 (3)

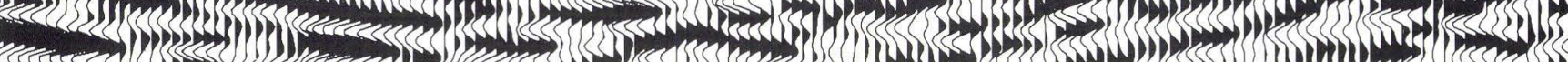

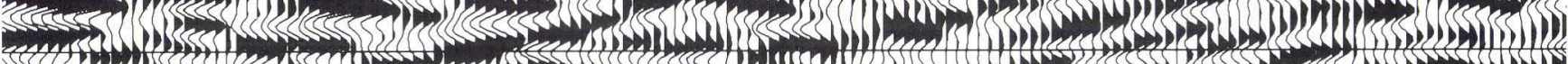

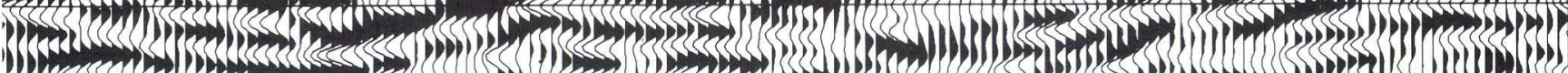
1) Her.

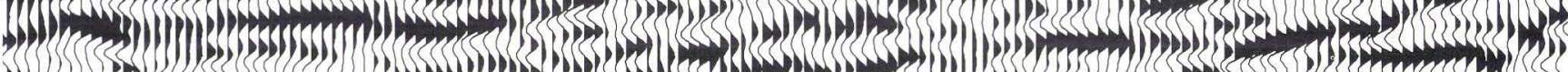

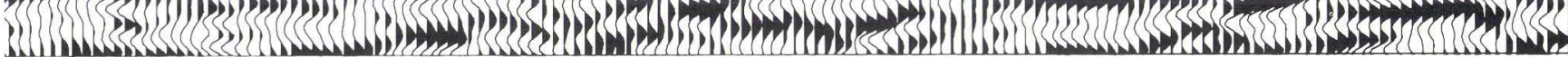

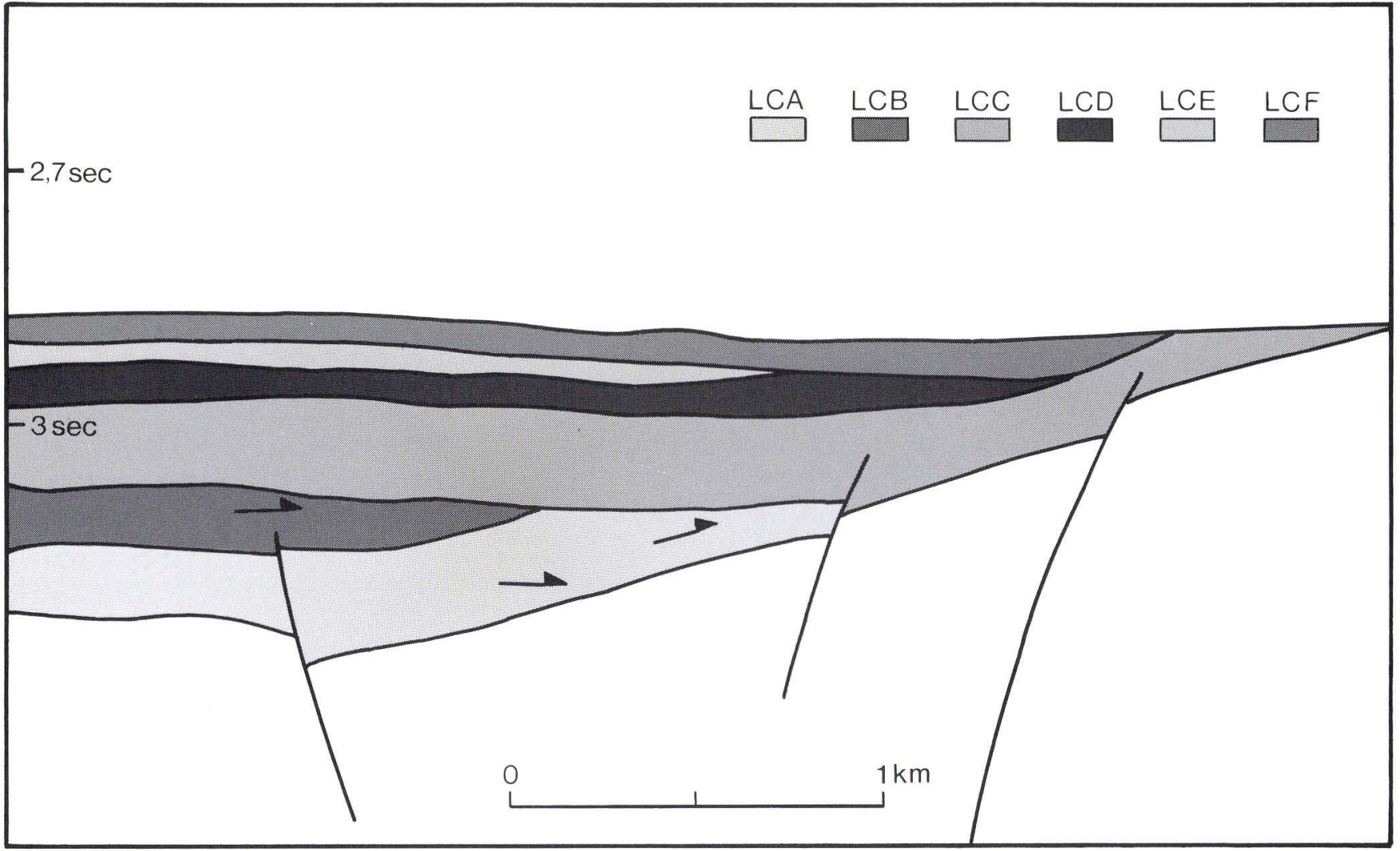

Fig. 21: This section 9 is located at the northeastern margin of the Tail End Graben. Note truncation of unit LCA, LCB, LCD, $L C E$ and LCF. For location see fig. 4. 
are less than the vertical seismic resolution, which is estimated to be about $25 \mathrm{~m}$.

\subsection{Unit LCA}

This unit is the lowermost of the seismic sequence units of the Lower Cretaceous sequence (figs. 17 and 19). The age of the unit is approximately Late Ryazanian to Early Valanginian (fig. 18). The unit is bounded downwards by the TJ reflector and upwards by the LCB or LCC units. The TJ reflector is interpreted by the aid of well-ties. It is assumed that it represents the boundary between the Upper Jurassic Farsund Formation and the Valhall Formation as discussed above. The internal reflectors are partly concordant but are mainly seen to onlap or downlap onto the basal TJ reflector (compare encl. 1), whereas the reflectors are in part concordant, and in part show a toplap relation to the upper boundary of the unit (fig. 20). The unit has the smallest areal extent as compared to the other units of the Lower Cretaceous sequence and is thus generally covered by the following LCB unit, but in the eastern part of the Salt Dome Province, the unit is directly overlain by the LCC unit area close to the Ringkøbing-Fyn High (figs. 17, 19, 23 and 24). Although the unit has the smallest areal extent, it has the most pronounced depocentres. The depocentres are located in the assumed Arne-Elin Graben wrench fault trend which continues to the north into the NE bounding fault of the Gertrud Graben and to the south into the depression west of the E-1 well (block 5504/11, fig. 19). However, the last of these depocentres is seen to be of a rather limited thickness whereas the middle and northern part of the fault- system is associated with very conspicuous depocentres. The subsidence of these depocentres is thought to have been caused by extensional block-faulting under the influence of left lateral extentional wrenching. The actual mode of subsidence appears to have varied in the different basins. In the northern part, subsidence was caused by rotational block-faulting under influence of wrenching. In the middle part the movement was a result of wrench generated graben faulting related to the continuing development of a transtensional flower structure (see discussion above). The southern part is heavily overprinted by halokinesis, which here is believed to have been controlled by transtensional wrench faulting also.

Besides these depocentres, others are found in the Feda Graben, in the eastern part of the Tail End Graben and in the northern part of the Salt Dome Province, (west of E-1 well, block 5504/11). All of these depocentres were caused by rotational block-faulting, but with slightly different characteristics. In the Feda Graben the depocentre of the unit is situated in a saucer-shaped depression (fig. 5, encl. 6) and does not lie next to the SW bounding fault (fig. 19). This is inter- preted as due to downwarping of the central part contemporaneously with faulting. The downwarping is probably due to differential compaction of the thick Upper Jurassic deposits (more than $1.5 \mathrm{~km}$, figs. 19 and 5).

In the Gertrud Graben, where Upper Jurassic deposits are much thinner, the basin floor has responded more rigidly to the block-faulting, and the depocentre is closer to the northeastern border fault (figs. 6 and 19). In the Tail End Graben the eastern depocentre is strongly elongated owing to the presence of a the minor compressional ridge in the centre of the graben, which was caused by wrench faulting as described on page 17 (figs. 19 and 14). Differential compaction may also have contributed to subsidence owing to compaction of the more than $4 \mathrm{~km}$ thick Jurassic sequence (Andersen et al. 1982).

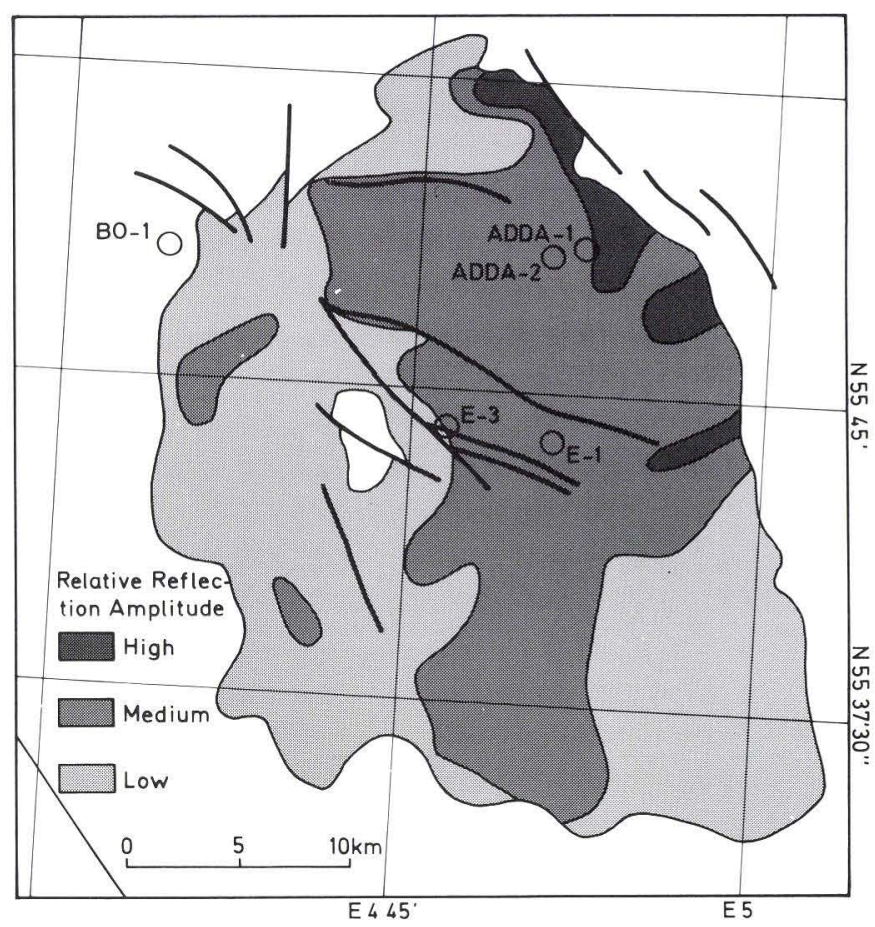

Fig. 22: Map showing relative amplitude variation of unit $L C A$ in the Salt Dome Province. Increased reflectivity within the Lower Cretaceous units is caused by increased carbonate content (locally as limestone layers) or by slightly increased coarse clastic content (mainly silt size). Well data indicate that increased reflectivity caused by increased carbonate content is associated with great continuity of internal reflectors whereas increased coarser clastic content is associated with discontinuous reflectors. High amplitude areas of this map are associated with discontinuous reflections.

In the Salt Dome Province a very broad depocentre is found just SE of the eastern depocentre of the Tail End Graben (block 5504/8 and 16, fig. 19). This is thought to have resulted partly from rotational blockfaulting, but mainly from differential compaction.

The unit has a lobate lensoid shape (figs. 16 and 19). Internally the unit has a low angle sigmoid progradational reflection pattern (sensu Vail et al. 1977), indica- 
ting southwesterly transport (fig. 20). A proximal/distal relation of the main transport direction may also be deduced from relative reflection amplitudes within the unit (fig. 22), because increased reflection amplitude is likely to indicate abnormal lithologies within the Valhall Formation. The map shows increased internal reflection amplitude in the direction of the V-1 well, which contains the type section of the Late Ryazanian -
Early Valanginian Vyl Formation composed mainly of silt and sand (Jensen et al. 1986). Hansen and Buch (1982) has suggested that large parts of the Valhall Formation were deposited in a submarine fan environment, because numerous finning-upwards sequences with thicknesses of 10-20' have been reported to be present in the Valhall Formation in several wells. Furthermore, the Valhall Formation contains relatively

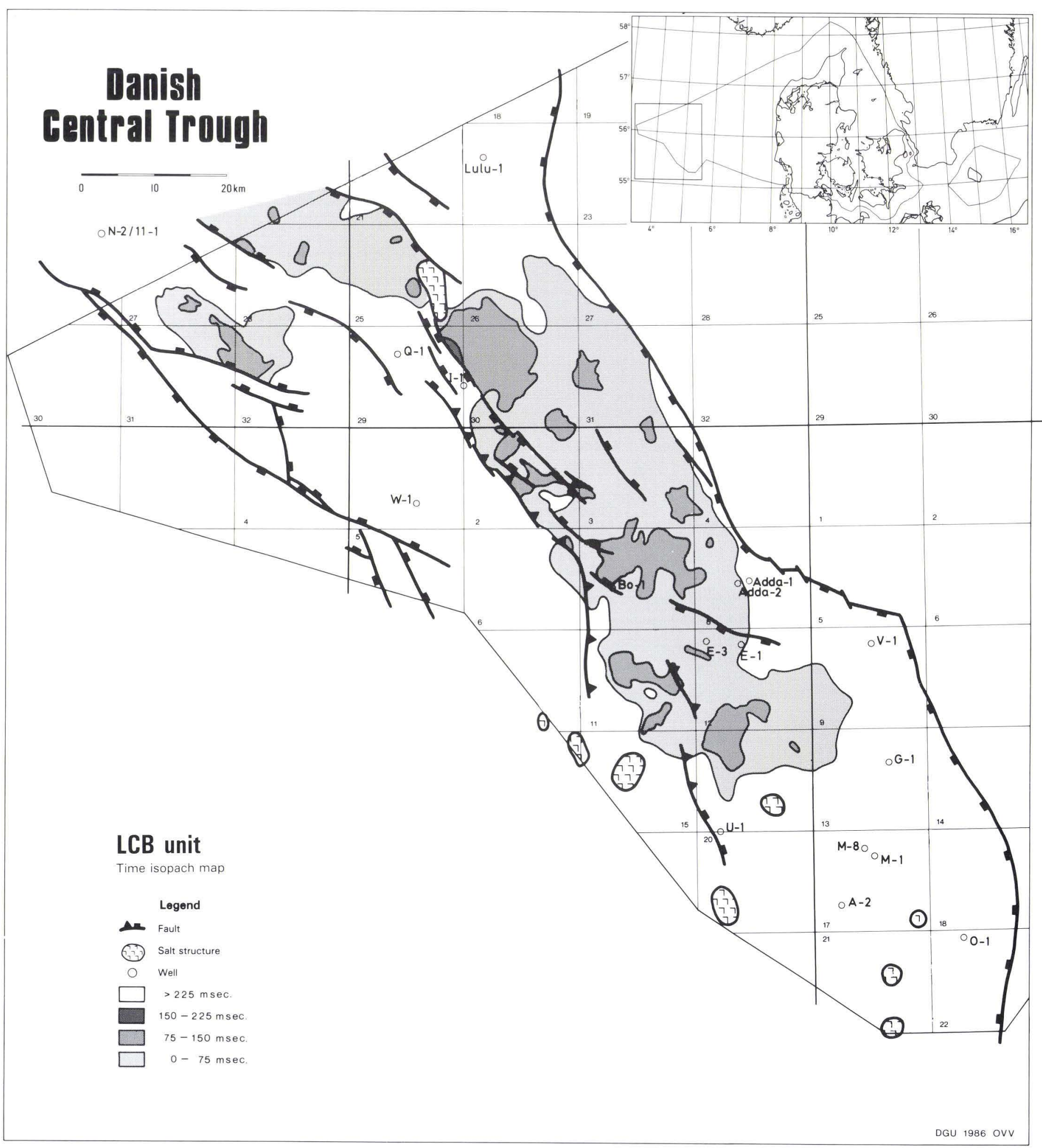

Fig. 23: Seismic distribution of unit LCB, expressed by TWT isopachs for the unit. See enclosure 7 for greater detail. 
large amounts of terrigenous organic material and reworked microfossils, (Triassic - Jurassic), which also may indicate a submarine fan environment (Hansen and Buch 1982, Hoelstad in prep.). It is therefore suggested that some sort of gravity flow was the most important depositional mechanism. Dipmeterlog interpretations by T.F. Jensen (pers. comm. 1985) seem to confirm this process to be of considerable importance throughout the Lower Cretaceous. The seismic data suggest that this sort of influence is most pronounced on unit LCA, and especially in the Salt Dome Province, which is the only place where unit LCA seems to affect the distributional extent of unit LCB (cf. fig. 23). In large parts of the Salt Dome Province unit LCB is seismically absent above unit LCA. This may be attributed to a more sufficient sediment supply for unit

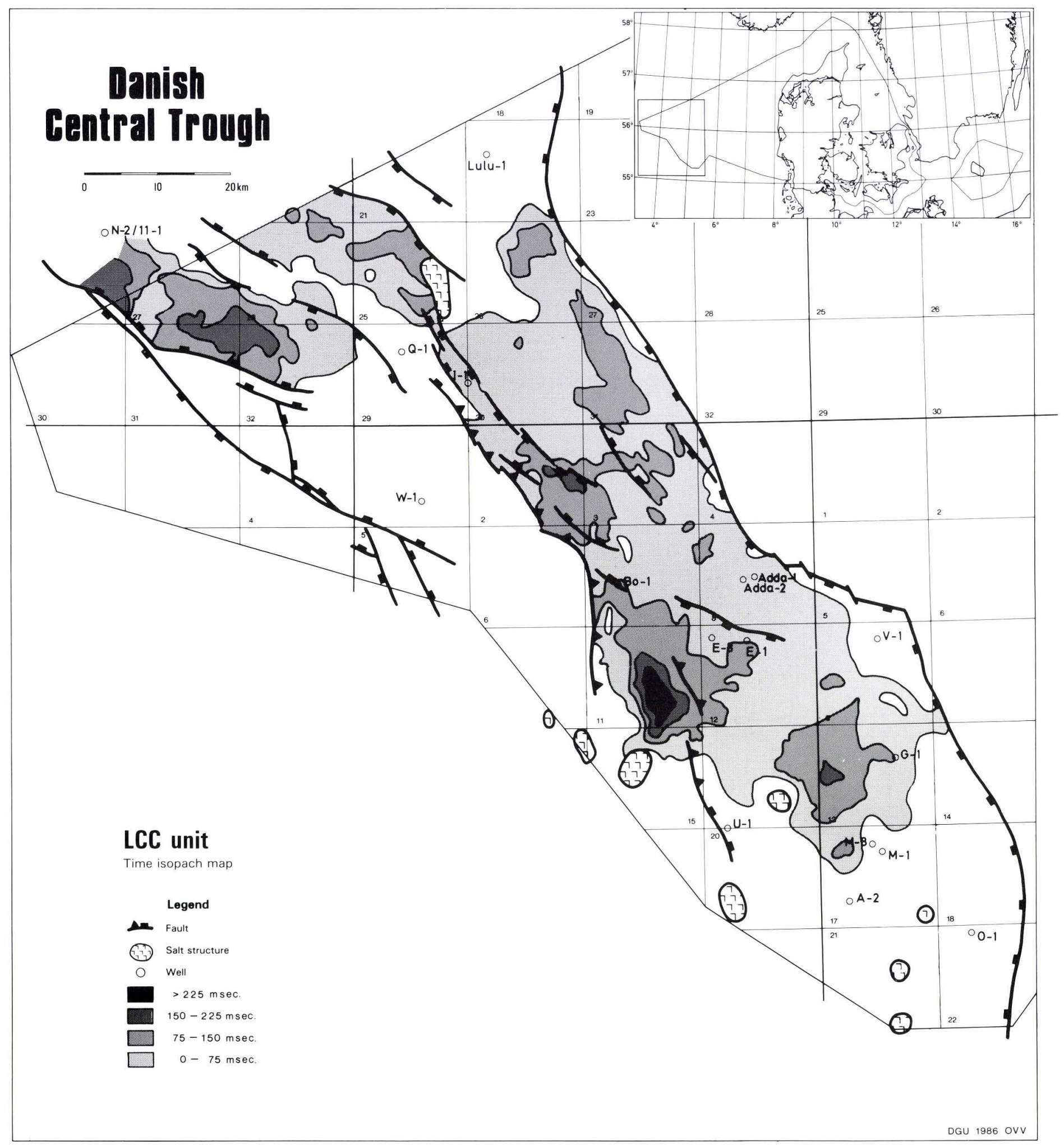

Fig. 24: Seismic distribution of unit LCC, expressed by TWT isopachs for the unit. See enclosure 8 for greater detail. 
LCA in the salt Dome Province in contrast to the other more sediment starved basins.

\subsection{Unit $L C B$}

The unit represents a further expansion of Lower Cretaceous deposits and thus covers unit LCA in most places except in the Salt Dome Province (encl. 7 and fig. 23). Well data indicate that the unit is of an Early Valanginian age (fig. 18). Thus in marginal areas the unit lies directly on top of the Upper Jurassic sequence. The unit is followed upwards by the LCC unit, which again covers the LCB unit in most places except, for instance, in the northern part of the Tail End Graben, where the unit is followed by unit LCD (cf. figs. 23 and 24). The upper boundary seems to be correlatable with the log-defined marker "A" (fig. 18, Jensen et al.
1986). The internal reflectors of the LCB unit generally show concordance with or onlap onto the substratum and concordance to or slight truncation by the overlying sequence (fig. 25). Unlike the other units in the Lower Cretaceous, the unit does not have any conspicuous depocentres, which may reflect a decreased rate of deposition owing to a reduced importance of gravity flow compared to pelagic deposition. This is also suggested by the concordant nature of the internal reflectors. The unit is generally thought to have been deposited in basins that were not much modified from the previously established basins, which means that the unit represents a further fill of the previously established basins and a lateral build out upon unit LCA.

Some minor tectonic activity is, however, visible. In the Feda Graben a depocentre in contact with the southwest boundary fault suggests some synsedimentary movement of the fault (fig. 23).
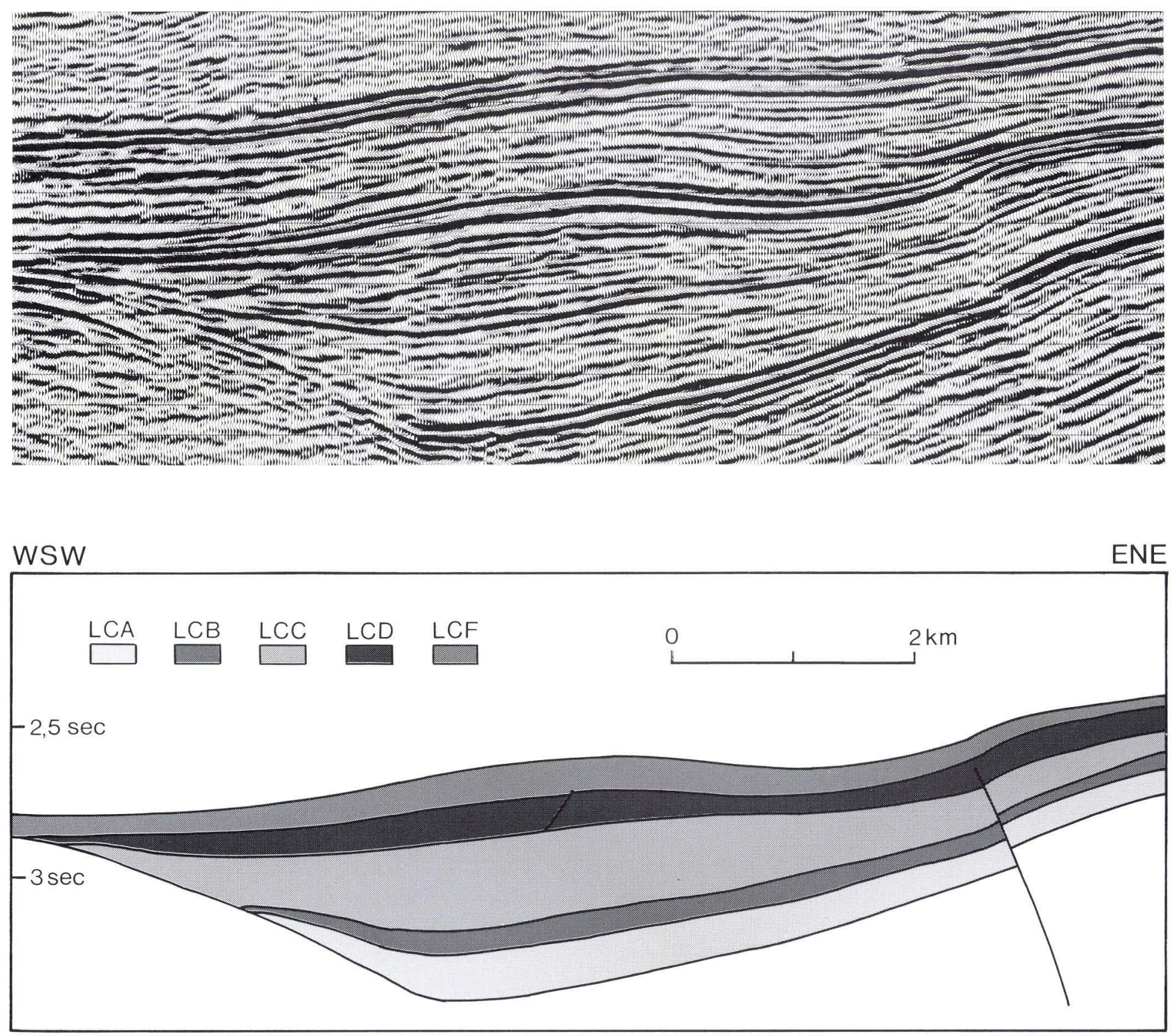

Fig. 25: Close up of the depocentre in the Salt Dome Province. Note concordance of internal Upper Jurassic reflectors with the base of the Lower Cretaceous. The LCF unit shows typical divergence of internal reflectors into the depocentre. 
A depocentre in the northwestern part of the Tail End Graben indicates that some normal faulting also occurred along the southeastern extension of the fault bounding the Gertrud Graben to the north-east. Similarly small depocentres are found in the Arne-Elin Graben indicating tectonic activity. In contrast to the previous unit, unit LCB has been influenced by little or no rotational block-faulting in the Tail End Graben. Between the Tail End Graben and the Salt Dome Province the presence of a depocentre indicates the filling of the gap between the two subbasins of the underlying LCA unit indicating that the Pollerne Ridge had lost its influence on sediment distribution. In the Salt Dome Province, two small depocentres are found in the western part. A new depocentre is also seen in the southern part. Both of these depocentres may owe their existence to downwarping as a result of halokinesis. The halokinesis is probably controlled by wrench faulting (fig. 10).

\subsection{Unit LCC}

Further basin expansion accompanied the deposition of unit LCC. Unit LCB is therefore covered almost everywhere by unit LCC, which onlaps Upper Jurassic structural high in marginal areas (encl. 8 and fig. 24). The unit probably has a Valanginian to Early Hauterivian age. The unit is overlain everywhere by the LCD unit. The internal reflectors of unit LCC are concordant or onlap/downlap onto the substratum. The internal reflectors are concordant with the upper boundary, but truncation and/or toplap is seen locally. The thickness variation of the unit demonstrates a renewed increase in tectonic activity, since conspicuous depocentres were developed. In the Feda Graben subsidence was comparatively rapid. The distance between the southwestern bounding fault and the depocentre may again indicate that a component of differential compaction of the thick underlying Jurassic sediment (cf. Gowers and Sæbøe 1985, fig. 5), again has contributed to subsidence. In the Gertrud Graben among others, - a minor lobate-elongate depocentre stretches from the northeastern fault into the basin and may indicate continued fault activity. In the Tail End Graben, the northwestern depocentre of the underlying LCA and LCB (block 5604/31 fig. 24) units has lost its importance, and instead unit LCC is mildly truncated by the LCD unit. The assumed central compressional wrench system seems to have had decreased importance, and rotational block-faulting continued (fig. 14). The Arne-Elin Graben contains a depocentre coinciding with, or a little north of the LCA depocentre. To the south a very conspicuous depocentre developed in the western part of the Salt Dome Province. This is attributed to increased extension as a result of wrenching along the Arne-Elin Graben fault-system. Another pronounced depocentre developed in the southern part of the Salt Dome Province mainly owing to salt movement.

\subsection{Unit LCD}

The deposition of this unit was accompanied by further basin expansion. The unit has a Hauterivian age approximately. The unit shows still greater onlap on structural highs compared to the LCA, LCB and LCC units, and the basins coalesced into one. For the first time full connection with Lower Cretaceous basins in the German sector of the North Sea was established (fig. 26). The unit therefore covers all previous units and onlaps the Upper Jurassic substratum along the margins of the extension of the unit.

The base of the unit locally truncates underlying sequences at low angles, especially on structural highs. Internal reflectors are mostly concordant to the base of the sequence, but downlap occurs, mainly in depocentres (fig. 27). The top of the sequence is commonly truncated at a low angle by overlying sequences, both by the LCE unit, the LCF unit (which covers the unit in more than half of the area) and the Upper Cretaceous sequences (e.g. fig. 20). This truncation, although mild, may have distorted the apparent amount of subsidence as deduced from the map (see fig. 26), but since the subsidence pattern shows many similarities with that of the previous unit and truncation angles are small if present, the amount of removed material is considered to be minor.

In the Feda Graben, subsidence is seen to have continued, presumably with continued differential compaction of the underlying thick Jurassic sequence, but only small thicknesses accumulated. Conversely, the Gertrud Graben shows conspicuous rotational blockfaulting, with thicker deposits accumulated than for the previous units. Compared to unit LCA the depocentre is further south, northeast of the Q-1 well, possibly as a result of a halokinetic influence (salt-flow into the salt structure, located in the northern end of the Arne-Elin Graben). Note the inundation of the Gert Ridge between the two basins (figs. 5 and 26).

In the Tail End Graben, rotational block-faulting had almost ceased, which may be indicated by the uniform thickness. The influence of the assumed compressional wrench ridge in the centre of the basin had decreased, and the ridge was thus inundated. The normal faultgenerated depocentre in the northwestern part of the graben gained new importance. In the Arne-Elin Graben a conspicuous depocentre also indicates the continuation of wrench-related normal faulting.

Some subsidence may also be indicated in the western part of the Salt Dome Province, but the unit is generally rather uniform in this basin, owing maybe to truncation by the LCF unit. 


\subsection{Unit LCE}

This unit is not found in the Salt Dome Province but only in the northern part of the Danish Central Trough (fig. 28). The unit has only been drilled in the I-1 well and is believed to be of a Late Hauterivian age. The connection between the Gertrud Graben and the Tail End Graben was no longer present, and the connection between the Feda Graben and the Gertrud Graben was again restricted. Internal reflectors are generally concordant with the base and are frequently truncated at the top (although at low angles). The areal extent of the unit is much more restricted than underlying units, representing a change in the general trend of the Lower Cretaceous with respect to basin expansion. The limited extent, however, is believed to be due to later ero-

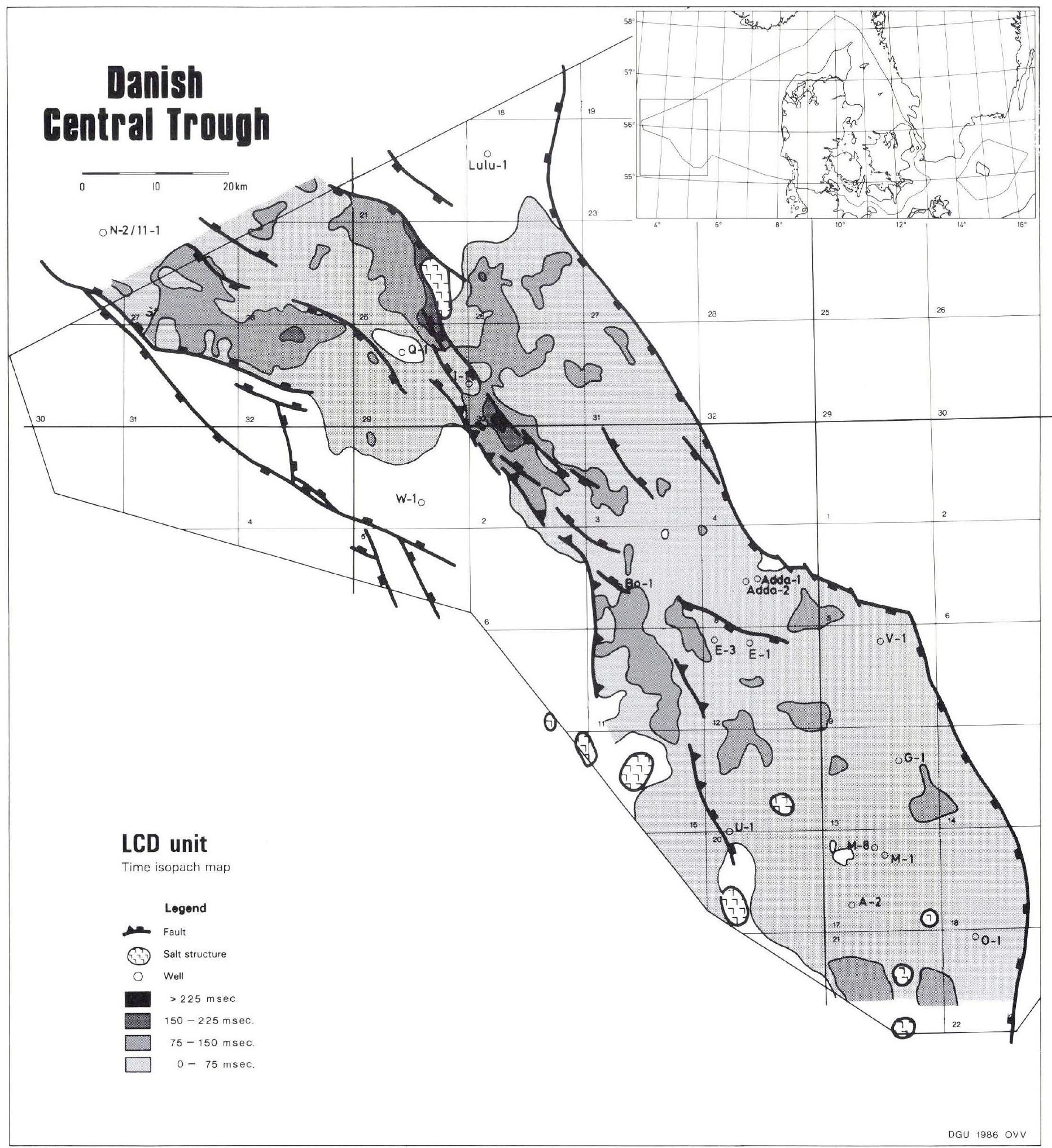

Fig. 26: Seismic distribution of unit LCD, expressed by TWT isopachs for the unit. See enclosure 9 for greater detail. 
sion, because the distribution of the unit is mainly controlled by the truncation of the lower bounding reflector against the base of unit LCF (see encl. 4 and fig. 20). Conversely the unit can be seen to extend further than the LCD unit in the southwesternmost part and in the northern end of the Tail End Graben. The location and size of depocentres, like the areal extent of the unit, are therefore a result of both erosion and subsidence.

In the Feda Graben, the unit is terminated a short distance from the southwest bounding fault. This may indicate some uplift and possibly some erosion along the Inge High, Mads High fault-system. On the other hand the absence of the unit over parts of the Gert

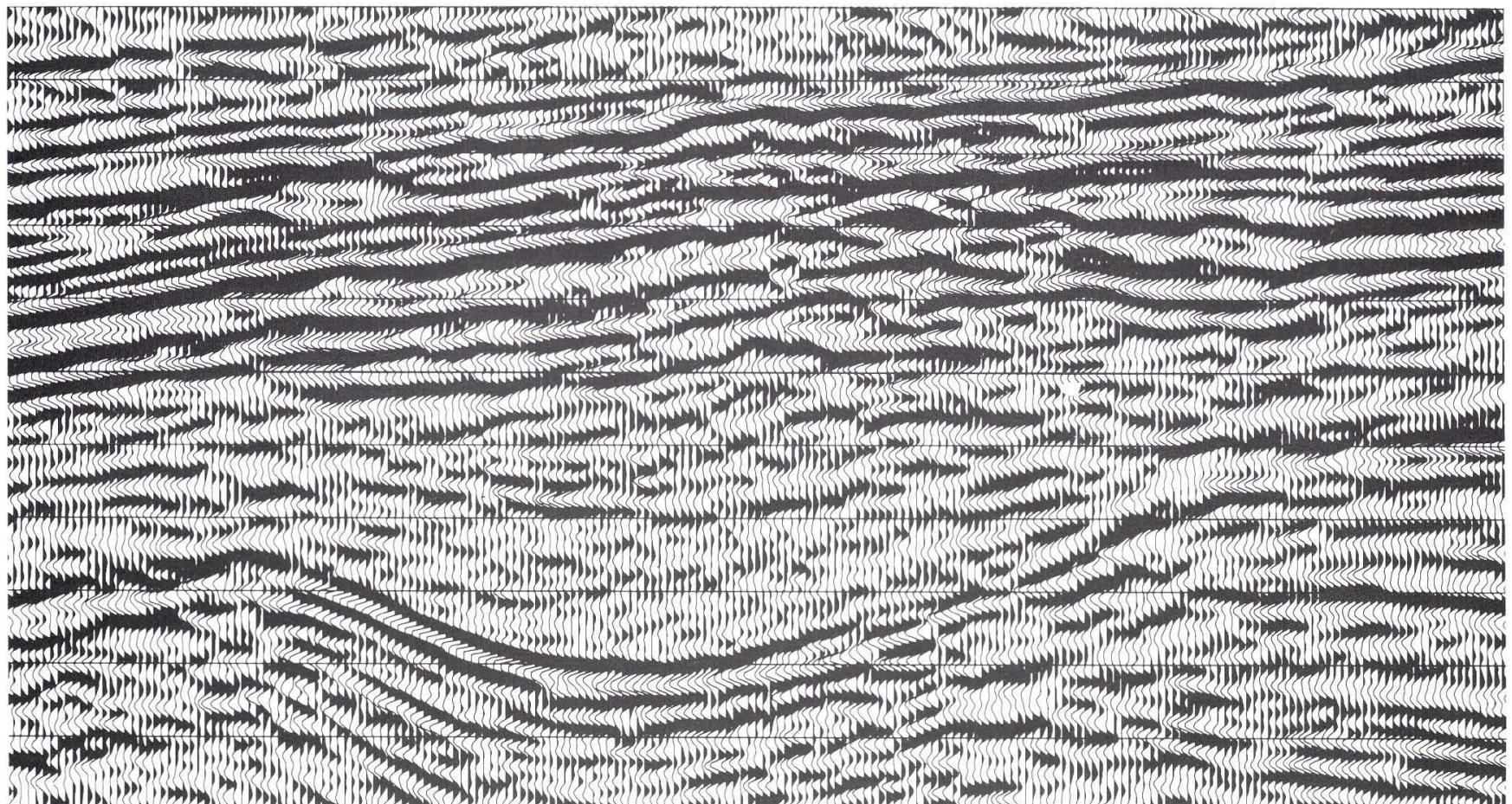

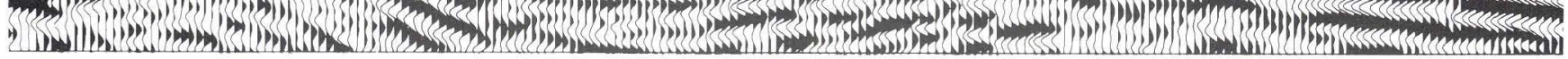
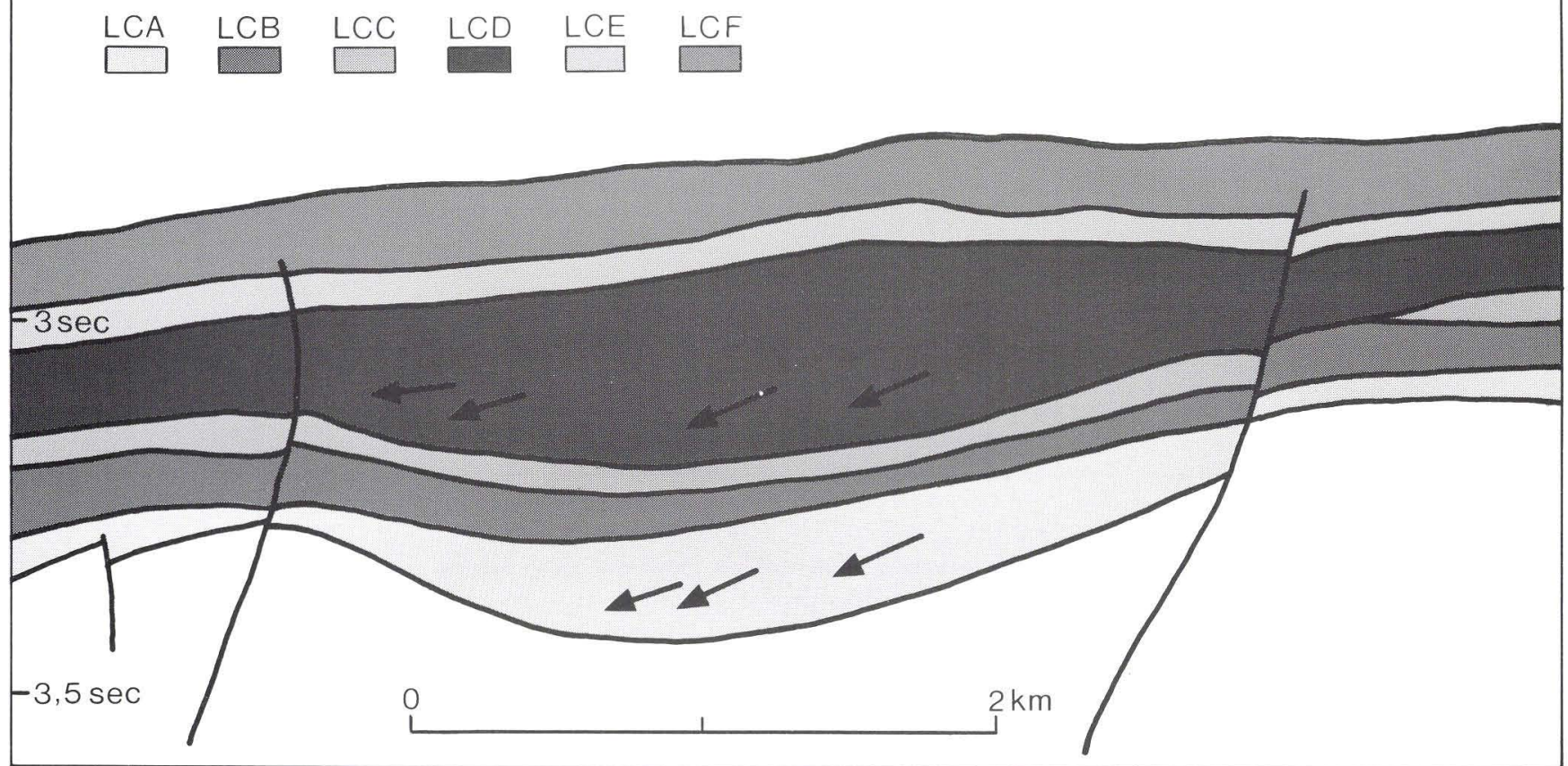

Fig. 27: Seismic section across one of the depocentres of unit LCD. Part of section shown in fig. 8. Conspicuous downlap is associated with the depocentre, which indicates that considerable horizontal sediment transport was associated with the deposition of the unit. A smaller LCA depocentre is also seen, having the same characteristics. 
Ridge and around the Q-1 well together with the depocentre (although very small) in the central part of the Feda Graben, indicate the continued importance of extensional block-faulting.

In the Gertrud Graben, uplift and erosion has affected a larger area close to the northeastern fault (probably) as a result of post depositional uplift and erosion caused by reverse faulting.
In the Arne-Elin Graben, continued transtensional wrench faulting created another small depocentre. In the southern part of the Arne-Elin Graben a thinning of the unit compared to either side of the graben may be attributed to post depositional uplift and erosion (e.g. encl. and fig. 29), probably caused by compressional wrenching.

The reverse faulting of the Feda and Gertrud Graben

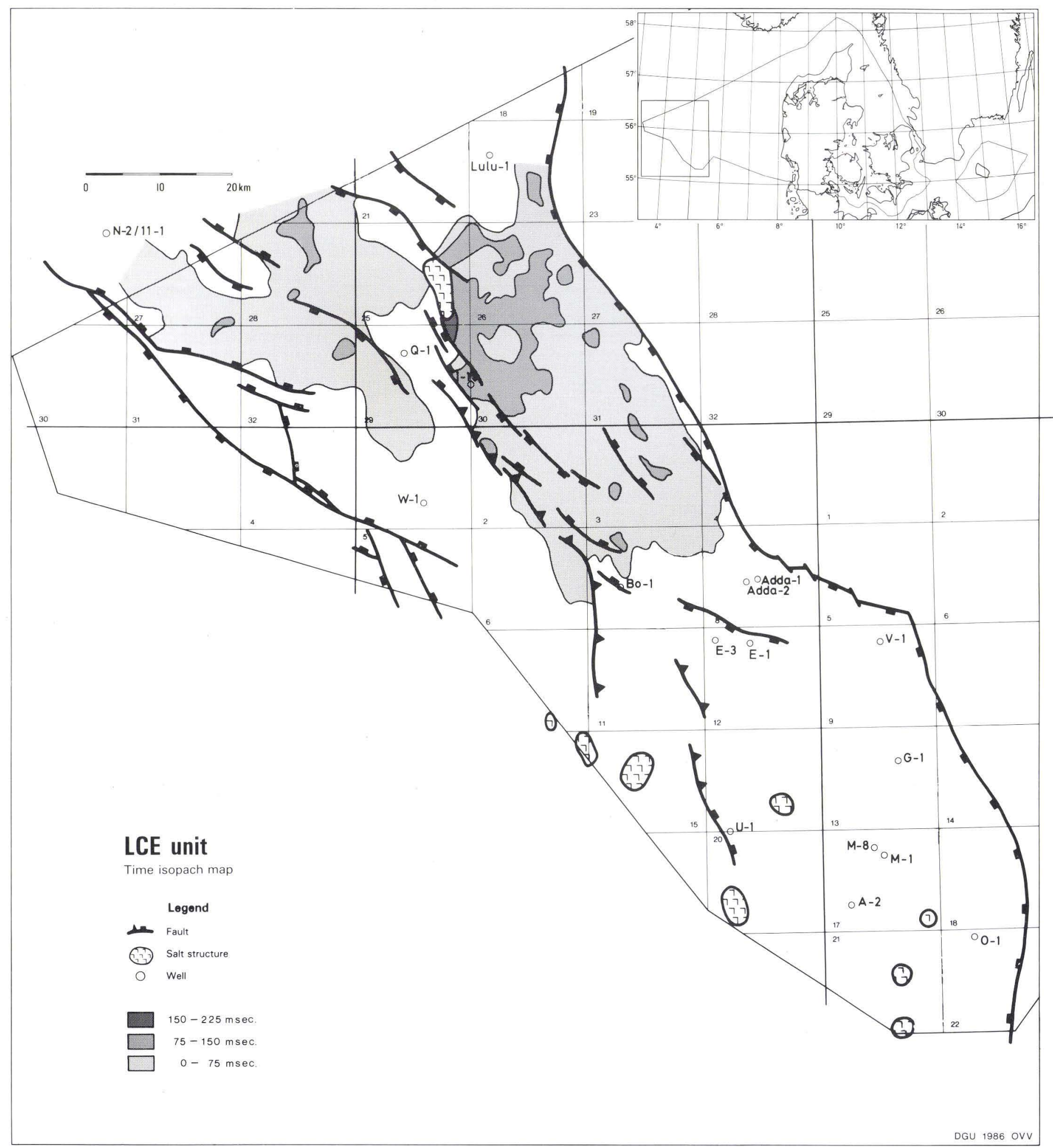

Fig. 28: Seismic distribution of unit LCE, expressed by TWT isopachs for the unit. See enclosure 10 for greater detail. 
boundary faults and the small uplift of the Arne-Elin Graben indicate that fault movement was characterized by compression. Compression along the northeast boundary fault of the Gertrud Graben can be achieved by right lateral strike slip. The same fault zones were influenced by much more significant compression in the Late Cretaceous, thus indicating similar movement pattern as during the Late Cretaceous inversion (figs. 6, 8 and 14). Normal faulting is responsible for the depocentre in the northwestern Tail End Graben close to the salt structure, but a central thin area may indicate the start of inversion tectonism, which led to the development of the Iris structure (Andersen et al. 1982) located above this Lower Cretaceous depocentre. This feature is also believed to have been accomplished by erosion following the small inversion of this Lower Cre- taceous depocentre (cf. fig. 28). Similarly, the absence of the unit close to the Ringkøbing-Fyn High is thought to be due to mild inversion. Some weak block-faulting may have occurred, giving rise to very small scattered depocentres close to the Ringkøbing-Fyn High. The absence of the unit in the Salt Dome Province may be attributed to both non deposition and erosion, also as a result of mild inversion tectonism.

\subsection{Unit LCF}

Renewed basin expansion accompanied the deposition of unit LCF, which covers almost the same amount of area as the LCD unit (compare figs. 26 and 30). The unit is believed to contain sediments of Late Hauteri-
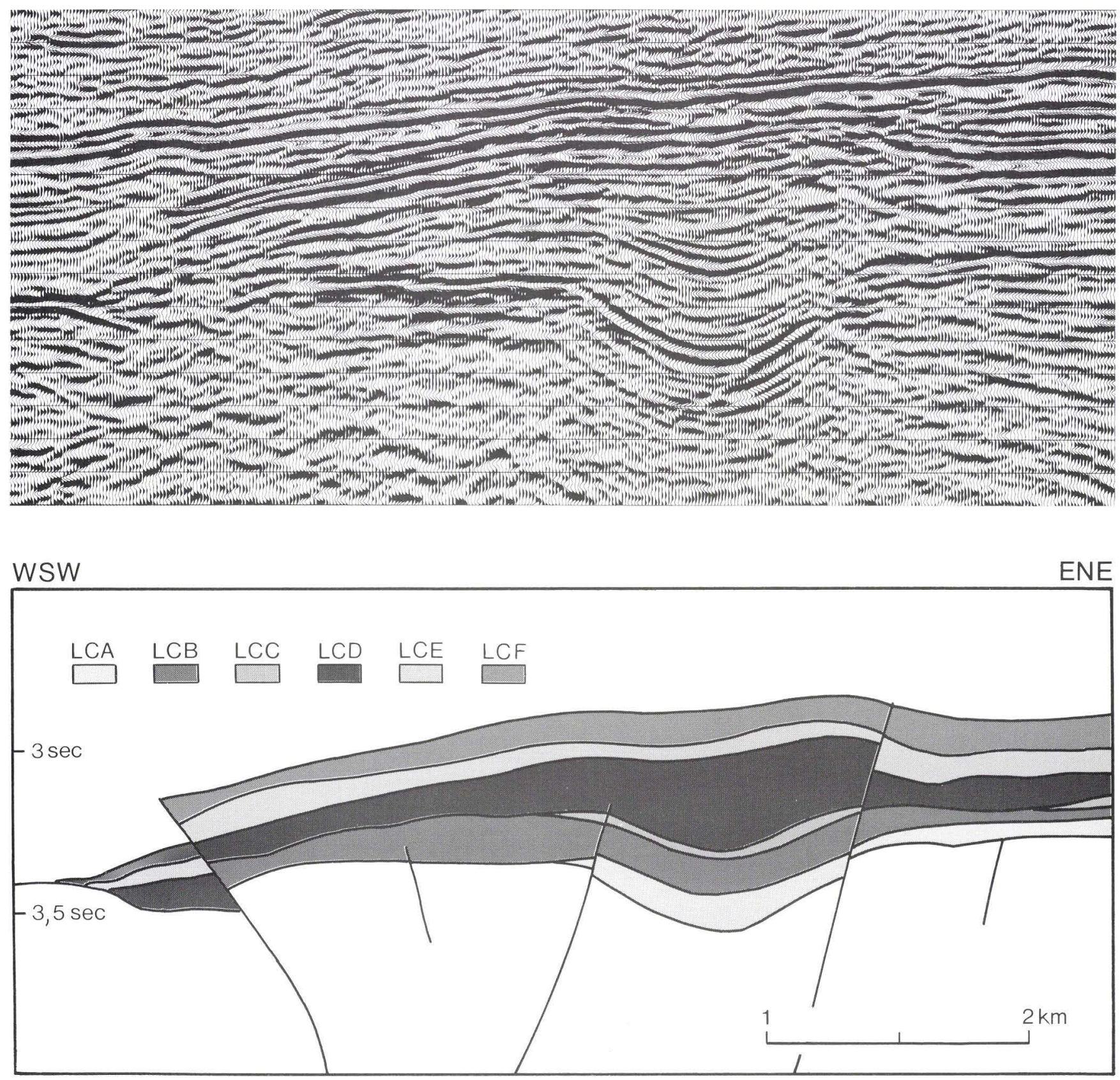

Fig. 29: This section 4 across the Arne-Elin Graben demonstrates the thinning of the LCE unit over the graben which is thought to be due to inversion. For location see fig. 4. 
vian to Albian (locally Cenomanian) ages. However, in this case also, the distribution is limited, to a great extent owing to later erosion caused by the Late Cretaceous inversion. The base of the unit seems to correlate with the base of the marls and limestones of the Tuxen Formation (Jensen et al. 1986). The basal reflector is created by this lithological boundary across which biozones are condensed or absent (Heilmann-Clausen in prep.).
The unit is characterized by internal high amplitude reflections of relatively high lateral continuity, more continuous than in underlying units. The internal reflections are parallel to the base of the unit and diverge into depocentres. Although it is a mild truncation, the base of the sequence shows a deeper truncation of underlying units than any of the internal Lower Cretaceous truncations. The top of the unit is characterized by concordance or truncation of internal reflections. The

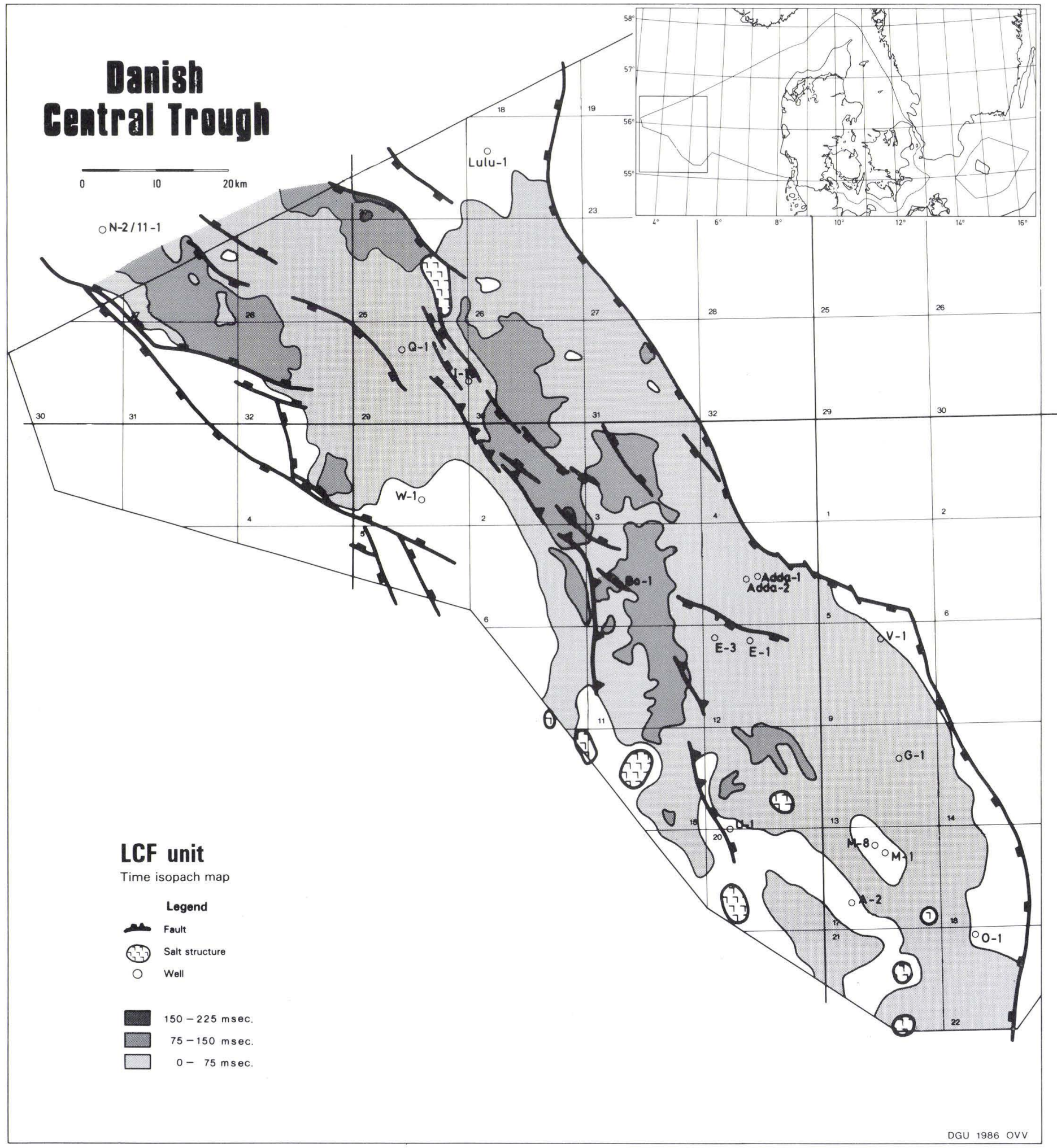

Fig. 30: Seismic distribution of unit LCF, expressed by TWT isopachs for the unit. See enclosure 11 for greater detail. 
chalk units of the Upper Cretaceous show very conspicuous onlap onto the top of this unit. The Tuxen, Sola and the Rødby Formations are thus embraced by this seismic unit (Jensen et al. 1986). It is noteworthy that the basal unconformity of this unit must have been caused by erosion during the Late Hauterivian according to the ages of the Tuxen Formation, and the Valhall Formation (fig. 18, Jensen et al. 1986). 'This unconformity appears not to be present (or has not been disclosed) in the Norwegian sector (Hesjedal and Hamar 1983). Instead an unconformity is reported present at the base (as defined by Hesjedal and Hamar 1983) of the organic carbon rich Sola Formation. This unconformity is interpreted by Hesjedal and Hamar (1983) as the result of a regression caused by the renowned Austrian tectonism of mid Aptian Age (Ziegler 1982). They further claim that the regression resulted in anoxia in restricted basins during the deposition of the Sola Formation (see discussion in Jensen et al. 1986). The possible unconformity cannot be resolved in the seismic data used in this study.

The unit is thought to have had a more widespread primary distribution than any of the previous units, which is seen by the encroachment of the unit onto the Heno Plateau and in the northern end of the Tail End Graben. Large areas have been affected by erosion, however, as a result of the Late Cretaceous - Early Tertiary inversion tectonism, which has limited the distribution of the unit. This is indicated by coincidence of the eroded area with the Late Cretaceous inversion areas as seen on enclosure 5 (cf. Andersen et al. 1982).

Although inversion tectonism already had been initiated, as described for the erosion of unit LCE, extensional faulting still had some importance. In the Feda Graben a broad and rather flat depocentre indicates some block-faulting. Small "holes" in this depocentre indicate slight erosion on the crest of the later inverted central part of the basin (compare encl. figs. 5 and 30 ). The unit is also seen to wedge out to the west as a result of inversion along the Mads-Inge High fault trend. A small depocentre also exists between the Inge and Mads Highs, and the unit probably continues across the ridge into the Outer Rough Basin, and does not terminate as indicated in the map (fig. 30). The wider distribution of the unit also resulted in complete inundation of the Gert Ridge and its southeastern continuation (including the Gwen structure, upon which the Q-1 well is situated). The Gertrud Graben again has a conspicuous depocentre against the northeastern bounding fault, indicating continued block-faulting.

In the Tail End Graben, continued transtensional wrenching resulted in a broad depocentre in the western part, but no block-faulting of any importance is evident. In the Arne-Elin Graben, an elongated broad depocentre indicates continued transtensional wrenching.

Transtensional wrenching may also be the cause for the broad depocentres found in the northern part of the Salt Dome Province. The north-south orientated depocentre of the Salt Dome Province, together with the depocentre that occurs in the central southern end of the Tail End Graben, is believed to have been caused by redeposition of sediments transported westwards from the Ringkøbing-Fyn High and transported eastwards from the structural highs located around and south of the Bo-1 well. These structural elements already existed in Early Cretaceous times as is indicated by the onlapping of the Lower Cretaceous units and the internal reflections of these units onto the substratum (fig. 16).

Large areas in the Salt Dome Province are devoid of the unit owing to erosion as a result of later inversion, as seen along the Ringkøbing-Fyn High and along the southwestern margin of the studied area. Inversion has also affected large areas where the unit is not appreciably eroded (cf. figs. 14, 16 and 5). The confinement of deep erosion to the southern part can be explained by an earlier inversion or greater inversional uplift in the southern end of the Danish Central Trough. This pattern is supported by isopach maps of the internal Upper Cretaceous chalk units (Lieberkind et al. 1982), which show absence or small thickness for the lowermost unit in the southern end of the Danish Central Graben. 


\section{Discussion}

\subsection{Tectonic evolution}

The tectonism of the Early Cretaceous was to a large extent a continuation of the tectonic pattern that governed the Late Jurassic structural development. According to Gowers and Sæbøe (1985) right lateral wrenching along WNW-ESE directions was responsible for the subsidence of the Feda Graben and Tail End Graben, as pull apart basins (cf. Crowell 1974, and figs 7 and 9). These directions decreased in importance in the Early Cretaceous, however, and the conjugated NNW-SSE direction started to be more active with left lateral transtensional wrenching.

Although normal faulting and associated wrenching is believed to be of importance throughout the Early Cretaceous, a conspicuous decrease in activity is obvious when comparing unit LCA and unit LCF (compare enclosed maps or figs. 19 and 30.) Several fault zones are seen to have become extinct on the LCF map and the rest are seen to have only slight effects on the thickness variation, as compared to the LCA unit map. This trend is interrupted by a period of quiescence coinciding with the deposition of unit LCB and a period of inversion resulting in minor erosion between unit LCE and LCF. The minor unconformity is believed to have been generated in the Late Hauterivian (Jensen et al. prep., Heilmann-Clausen in prep.; fig. 18). This development reflects the transition from the tectonism of the graben phase (cf. Harding 1983), that persisted through most of the Mesozoic and became extinct in the Late Cretaceous as regional subsidence commenced in the interior sag phase (Sclater and Christie 1980, Wood and Barton 1983). The period of regional subsidence was almost devoid of normal faulting but with initial events of inversion (the last being of Tertiary age). The present work demonstrates that there was a precursor of the Late Cretaceous inversion already in the latest Early Cretaceous. The onset of regional subsidence and initiation of inversion in the Late Cretaceous was accompanied by an abrupt change in the stress system that governed the area. The inversion was governed by right lateral compressional wrenching, which is best seen in the Arne-Elin Graben area, where previously normal faults were reactivated with significant reverse components (see fig. 31). The reduced crustal extension resulting in the extinction of graben tectonism is thought to be due to the initiation of sea floor spreading in the arctic North Atlantic in mid Cretaceous times

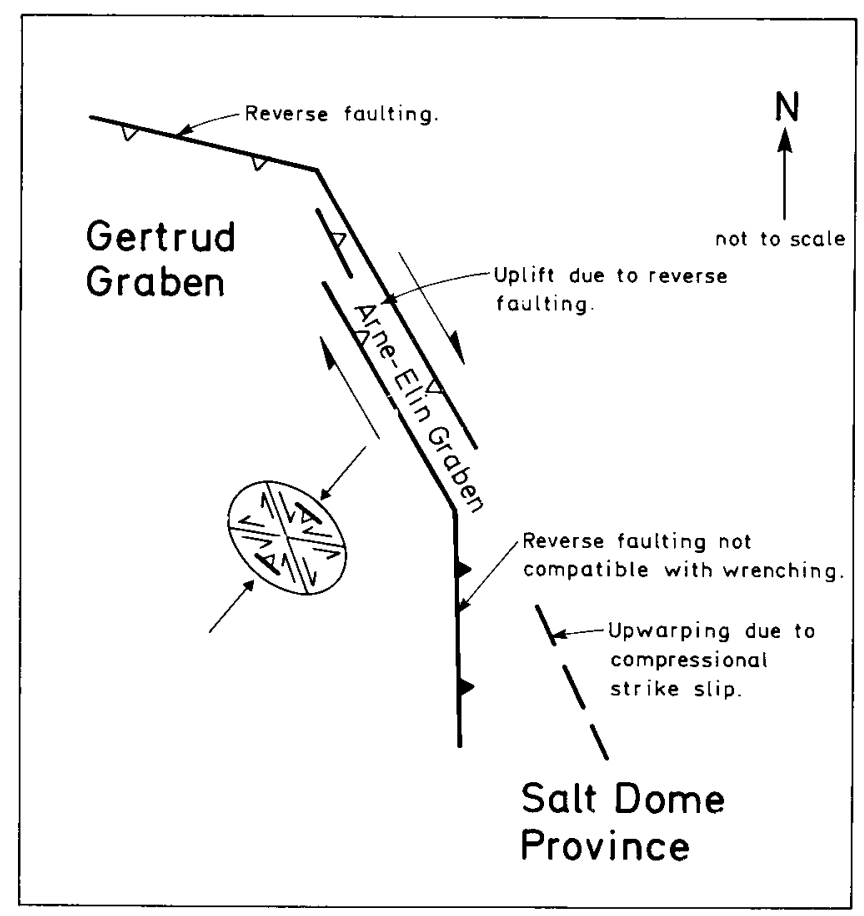

Fig. 31: The effect of the Late Cretaceous right-lateral compressional wrenching along the Arne-Elin Graben fault-system is here schematically illustrated. The compressional strike slip results in inversion of the Arne-Elin graben. The right lateral motion gives rise to compressional and reverse faulting in the Gertrud Graben. However, the system cannot account for compression to the south.

(Schlater et al. 1977). This event resulted in the rather abrupt re- orientation of stresses, and a transition from a tension dominated system to a compression influenced system. The major events of inversion are the main causes for the present relief of the Lower Cretaceous strata.

\subsection{Depositional history}

The development of the Lower Cretaceous is characterized by a general relative sealevel rise, starting with a low in the Volgian (Rawson and Riley 1982), and a general continued rise into the Late Cretaceous.

The boundary between the Upper Jurassic and the Lower Cretaceous has been claimed to be accompanied by a sea level drop at the end of the Ryazanian (Vail and Todd 1981) resulting in a change from anoxic black 
shales of the Kimmeridgian to Ryazanian Farsund Formation to the light grey oxygenated clays and marls of the Lower Cretaceous, and the development of the alledged Late Cimmerian Unconformity (fig. 33). The pronounced sea level drop resulting in a major (first order) unconformity at the base of the Valanginian as reported by Vail and Todd (1981) for the Viking Graben, however, cannot be shown to have occurred in the beginning of the Early Cretaceous on a similar scale in the Danish Central Trough. The increasing lateral extent of the seismic units covered by this work may also (at first glance) appear to lead to this conclusion, but in many areas, where the lower seismic units are absent well data indicate condensed sequences lacking major gaps (fig. 32). In many wells there is no hiatus across the Jurassic Cretaceous boundary (Heilmann-Clausen, in prep., Hoelstad, in prep.). The lithological equivalent to the seismic units may thus be present, but in thicknesses far below seismic resolution. The seismic lateral limition of the seismic units may therefore not be equivalent to the depositional area.

Instead of truncation between the Upper Jurassic and the Lower Cretaceous there is merely a divergence of internal Upper Jurassic reflectors into depocentres. The lithological change from black anoxic shales to light grey oxygenated clays and marls is believed to be the main cause for the impedance contrast responsible for the conspicuous "Top Jurassic" reflector. The relative sealevel rise resulted in well oxygenated bottom waters, because submarine swells no longer could hamper circulation in the water body (cf. Demaison and

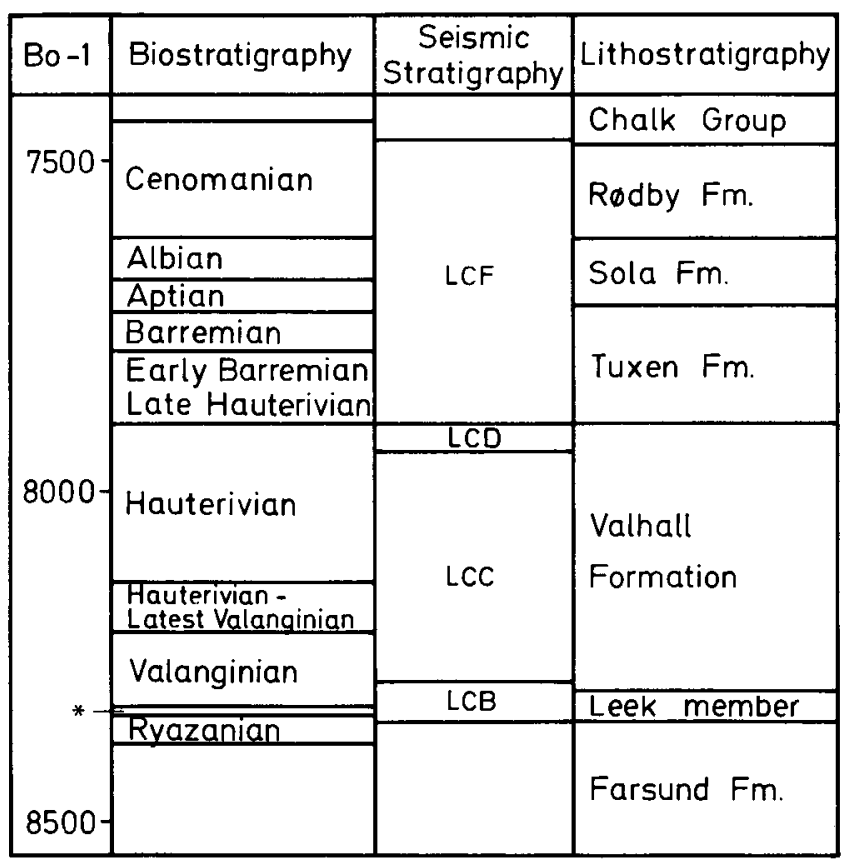

* Early Valanginian

- Late Ryazanian

Fig. 32: The biostratigraphical subdivision of the Bo-1 well (Palaeoservice 1977) demonstrates the completeness of the Lower Cretaceous where the sequence is thin.

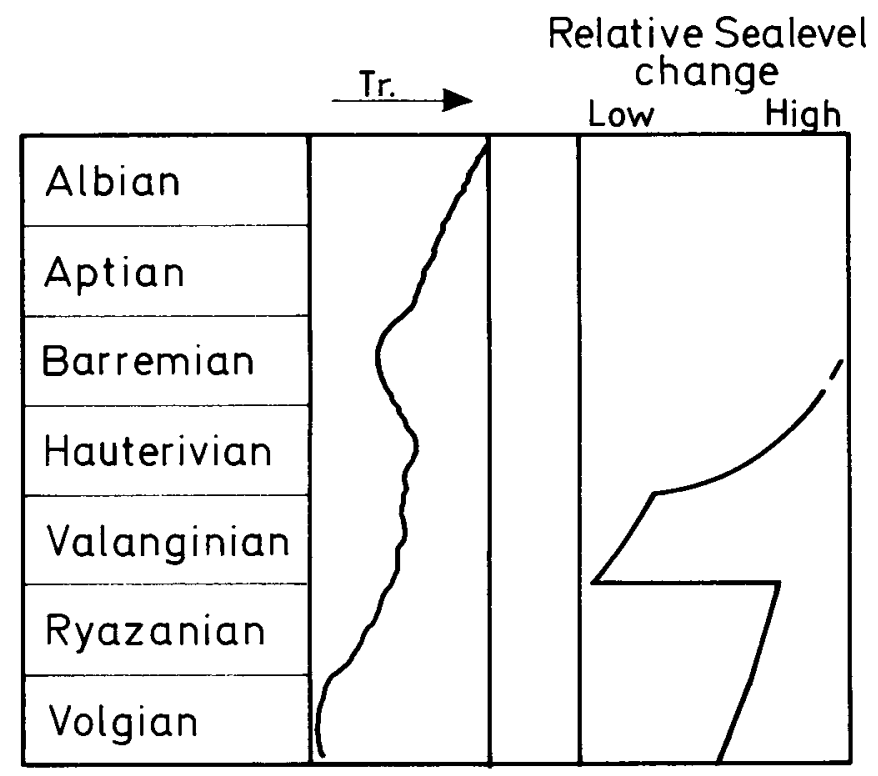

Fig. 33: Sea level curves, after Rawson and Riley (1982) (left) and Vail and Todd (1981) (right). The sealevel drop claimed by Vail and Todd (1981) to be a major unconformity at the base of the Valanginian in the northern North Sea cannot be recognized as such in the Danish Central Trough.

Moore 1980). At the same time redeposition became important, as current activity increased, leading to accumulation of sediments in topographical lows.

Throughout the Lower Cretaceous sequence, however, there seems to be a tendency for a decrease in the vigour of the depositional mechanisms, indicated by increasing horizontal continuity of internal reflectors and decreasing lateral thickness variation together with a pronounced onlapping trend of the internal sequences (see figs. 19, 23, 24, 26, 28 and 30). The rising sea level resulted in a decreasing influx of siliciclastics owing to the increasing remoteness of source areas. This is reflected in the sediments as a decreasing content of coarse clastics and by the introduction of pelagic limestones in the uppermost Lower Cretaceous unit LCF which is equivalent to the Tuxen, Sola and Rødby Formations (Jensen et al. 1986). The introduction of pelagic limestones is tentatively interpreted as arising from the combined effect of a decrease in clastic input and an increase in pelagic carbonate productivity across an Upper Hauterivian unconformity (cf. Jensen et al. 1986). A primary sealevel drop followed by a sea-level rise, as the seismic data alone might be taken to indicate, is thought to be somewhat erroneous. Instead of the sealevel curve based on seismic data by Vail and Todd (1981), the curve presented by Rawson and Riley (1982) is favoured for the Danish Central Trough. (fig. $33)$. 


\section{Acknowledgements}

The author wishes to thank the following companies for permission to publish the results of the interpretation of their seismic surveys from the Danish Central Trough: Nopec a.s., Seismic profilers U.K. Ltd. and Geophysical Services International. 


\section{References}

Andersen, C., Olsen, J.C., Michelsen, O. and Nygaard, E. 1982: Structural outline and development. - In: Michelsen, O. (ed.) Geology of the Danish Central Graben. - Danm. geol. Unders., Ser. B, 8, pp. 9-26.

Birkelund, T., Clausen, C.K. Hansen H.N., and Holm, L. 1983: The Hectoroceras kocki Zone (Ryazanian) in the North Sea Central Graben and remarks on the Late Kimmerian Unconformity. Danm. geol. Unders., Årbog 1982, pp. 53-72.

Crowell, J.C. 1974: Origin of Late Cenozoic Basins in Southern California. - In: Dickinson, Tectonics and sedimentation. - Soc. Econ. Pal. and Min. Spec. Publ. No. 22, pp. 190-204.

Demaison, G.J. and Moore, G.T. 1980: Anoxic Environments and Oil Source Bed Genesis. - Am. Ass. Petr. Geol. Bull. vol. 64, pp. 1179-1209.

Gowers, M.B. and Sæbøe, A. 1985: On the structural evolution of the Central trough in the Norwegian and Danish sectors of the North Sea. - Marine and Petroleum Geology, vol. 2, Number 4.

Hancock, J.M. 1982: Cretaceous. - In: Glennie, K.W. (ed.): Introduction to the Petroleum Geology of the North Sea, pp. 133-150.

Hansen, J.M. and Buch, A. 1982: Early Cretaceous. - In: Michelsen, O. (ed.) Geology of the Danish Central Graben. Danm. geol. Unders., Ser. B, 8, pp. 45-49.

Hansen, J.M. and Mikkelsen, N. 1983: Hydrocarbon geological aspects of subsidence curves: Interpretations based on released wells in the Danish Central Graben. - Bull. Geol. Soc. Denmark, vol. 231, pp. 159-169.

Harding, T.P. 1983: Graben hydrocarbon plays and structural styles. - Geol. Mijnbouw, vol. 62 (1), pp. 3-23.

Harding, T.P. 1985: Identification of strike-slip generated flowerstructures. - Am. Ass. of Petr. Geol. Bull. 69. (4).

Heilmann-Clausen, C., in prep.: Lower Cretaceous dinoflagellate biostratigraphy in the Danish Central Trough. - Danm. geol. Unders., Ser. A.

Hesjedal, A. and Hamar, G.P. 1983: Lower Cretaceous stratigraphy and tectonics of the south-southeastern Norwegian offshore. Geol. Mijnbouw, vol. 62 (1), pp. 135-144.

Hoelstad, T. in prep.: Palynology and palynofacies analysis of the Middle Jurassic to Lower Cretaceous in the Danish Central Trough. - Danm. geol. Unders., Ser. C.

Holm, L. 1983: Subsidence history of the Jurassic sequence in the Danish Central Graben. - Danm. geol. Unders., Årbog 1982, pp. 39-51.

Jensen, T.F., Holm, L., Frandsen, N. and Michelsen, O. 1986 (in press): Jurassic - Lower Cretaceous lithostratigraphic nomenclature for the Danish Central Trough. - Danm. geol. Unders., Ser. A.

Koch, J.O., Holm, L. and Michelsen, O. 1982: Jurassic - In Michelsen, O. (ed.) 1982: Geology of the Danish Central Graben Trough. - Danm. geol. Unders., Ser. B. 8, pp. 37-45.
Lieberkind, K., Bang, I., Mikkelsen, N. and Nygaard, E. 1982: Late Cretaceous and Danian Limestones. - In: Michelsen, O. (ed.) 1982: Geology of the Danish Central Graben. - Danm. geol. Unders., Ser. B, 8, pp. 45-49.

Michelsen, O. and Andersen, C. 1983: Mesozoic structural and sedimentary development of the Danish Central Graben. - In: J.P. M. Kaasschieter and T.J.A. Reijers (eds.): Petroleum geology of the southeastern North Sea and the adjacent onshore areas (the Haque 1982). - Geol. Mijnbouw, vol. 62. pp. 93-102.

Møller, J.J. in prep.: Seismic structural mapping of the Middle and Upper Jurassic in the Danish Central Trough. - Danm. geol. Unders., Ser. A.

Rawson, P.F. and Riley, L.A. 1982: Latest Jurassic - Early Cretaceous Events and the "Late Cimmerian Unconformity" in the North Sea Area. - Am. Ass. Petr. Geol. Bull. 66 (12), pp. 2628-2648.

Reading, H.G. 1980: Characteristics and recognition of strike-slip systems. - In Ballance and Reading (ed.): Sedimentation in oblique-slip mobile zones. - Spec. Publ. nr. 4 of the Int. Ass. of Sedim.

Schlater, J.G. Hellinger, S. and Tapscott, C. 1977: The Palaeobathymetry of the Atlantic Ocean from the Jurassic to the present. - Journal of Geology, vol. 85, pp. 509-552.

Sclater, J.G. and Christie, P.A.F., 1980: Continental streching : An explanation of the post-mid-Cretaceous subsidence of the central North Sea Basin. - Jour. of Geoph. Res., vol. 85, pp. 3711-3739.

Skjerven, J., Rijs, F. and Kalheim, J.E. 1983: Late Palaeozoic to Early Cenozoic structural development of the south-southeastern Norwegian North Sea. - In: J.P.H. Kaasschieter and T.J.A. Reijers (eds.): Petroleum geology of the southeastern North Sea and the adejacent onshore areas (the Hague 1982). - Geol. Mijnbouw, vol. 62 , pp. $35-45$.

Vail, P.R., Mitchum, R.M., Todd, R.G., Widmier, J.M., Thompson, S., Sangree, J.B., Bubb, J.N. and Hatlelid, W.G. 1977: Seismic Stratigraphy and global changes in sealevel. - In: Payton, C.E. (ed.): Seismic Stratigraphy - Applications to hydrocarbon exploration. - Am. Ass. Petr. Geol. Mem. 26, pp. 49-212.

Vail, P.R. and Todd, R.G. 1981: Northern North Sea Jurassic unconformities, chronostratigraphy and sea level changes from seismic stratigraphy. - In: Illing and Hobson (ed.): Petroleum Geology of the continental shelf of N.W. Europe. - Heyden and Son Ltd. for Inst. of Petroleum London, pp. 216-235.

Wood, R. and Barton, P. 1983: Crustal thinning and subsidence in the North Sea. - Nature, vol. 302, pp. 134-136.

Ziegler, P.A. 1982: Geological Atlas of Western and Central Europe. - Elsevier Scientific publ. co., Amsterdam 130 p. and encl. 


\section{Pertinent information on the data base}

The seismic data base consists of 6 different surveys of which 5 are speculative data shot by different seismic contractors, and one is company property shot by the DUC (table 2).

Table 2

\begin{tabular}{llll}
\hline Survey & $\begin{array}{l}\text { Contractor/ } \\
\text { Company }\end{array}$ & Type & Vintage \\
\hline CGT & Nopec & speculative & 1981 \\
RTD & Nopec & speculative & 1981 \\
MERLIN & Merlin & speculative & 1982 \\
DMK & GSI & speculative & 1982 \\
GSI 81 & DUC & propriety & 1981 \\
\hline
\end{tabular}

Only new 60 fold migrated data have been used, since older data do not have the quality necessary to resolve the details studied in this work. All the data were covered by a five year confidentiallity clause, and have been kindly released for publication by special permit from the different companies.

The line spacing shows great variation and is generally not very dense, as is evident from fig. 34. Furthermore, not all lines were used owing to differences in quality. The maps may therefore have minor flaws concerning reliability of structures on a local scale, especially in the southern part of the Salt Dome Province.

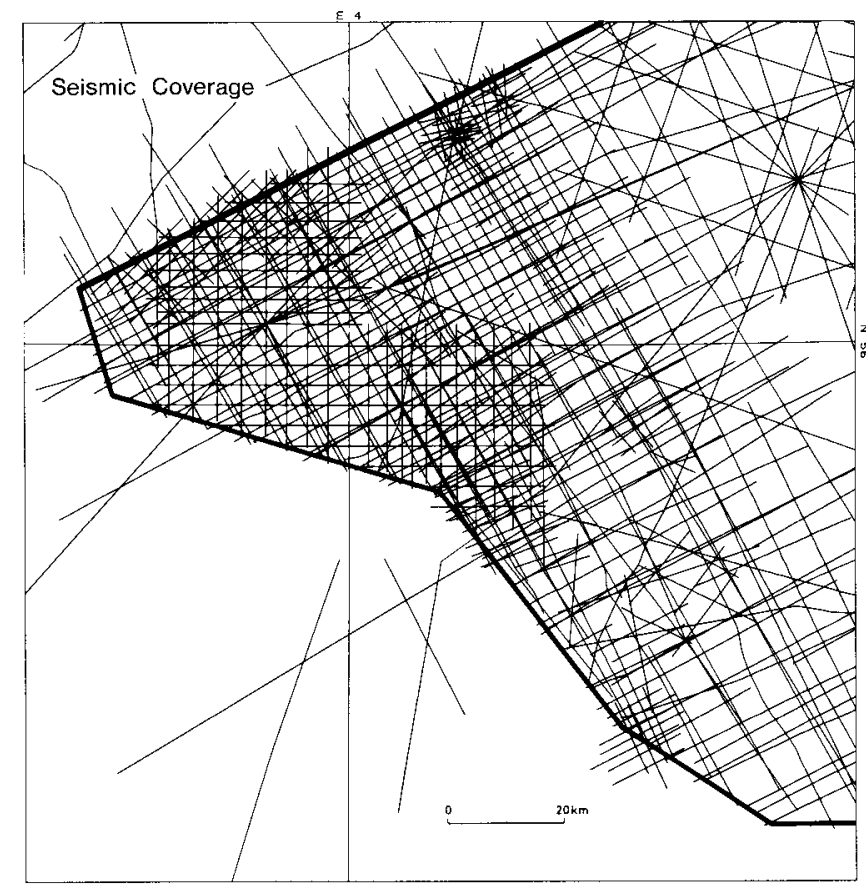

Fig. 34: The location af the 6 surveys used. 


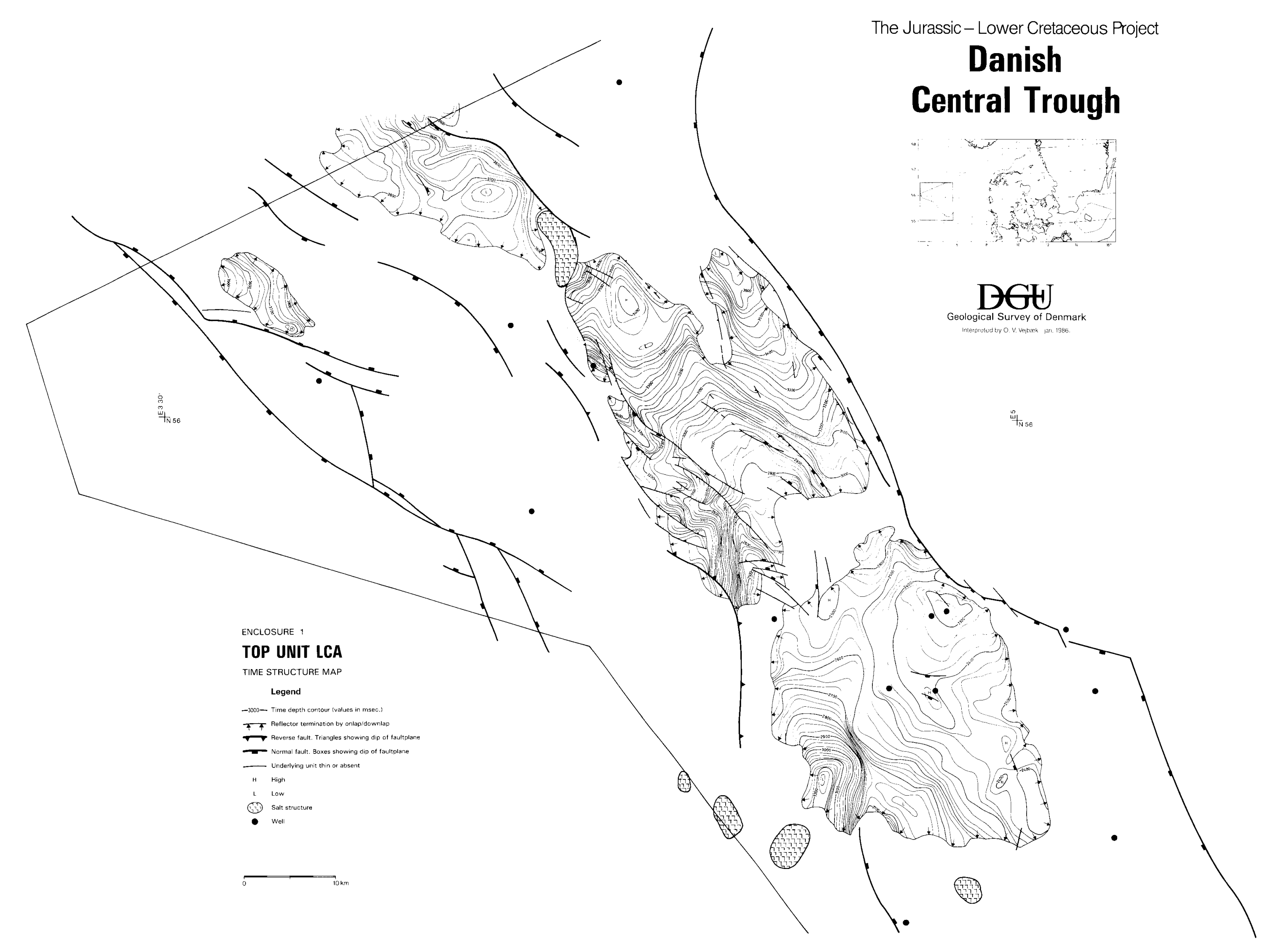




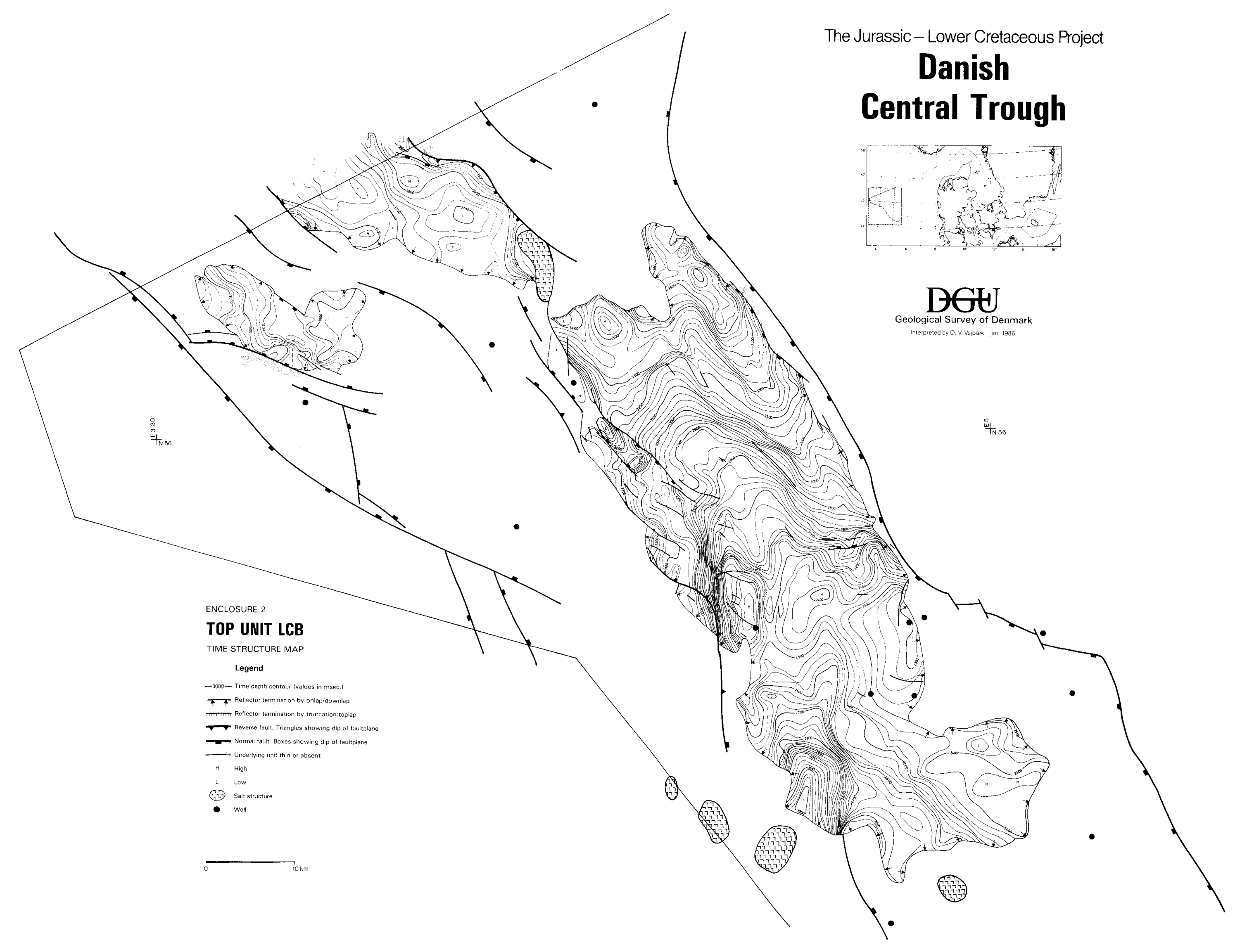




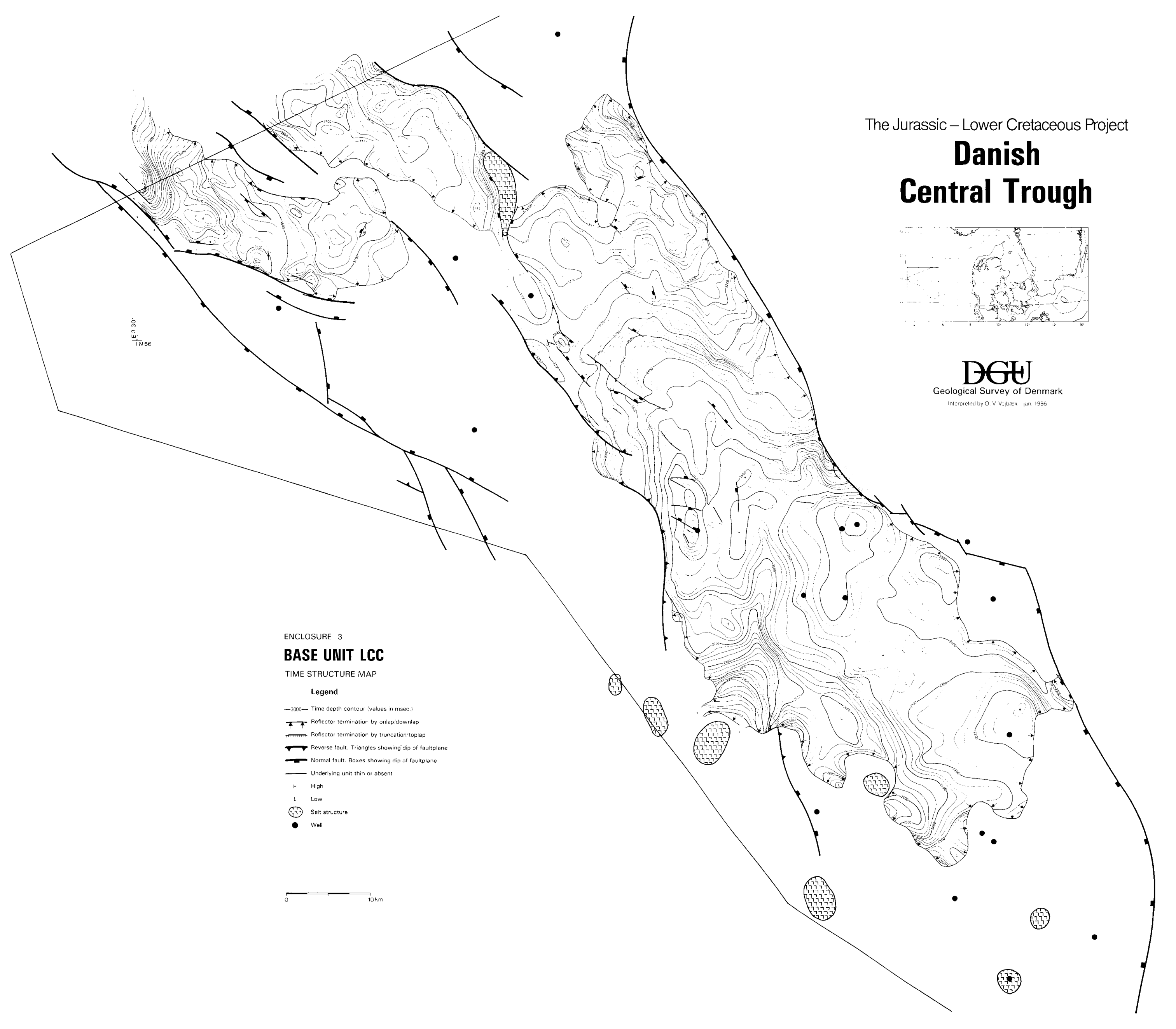




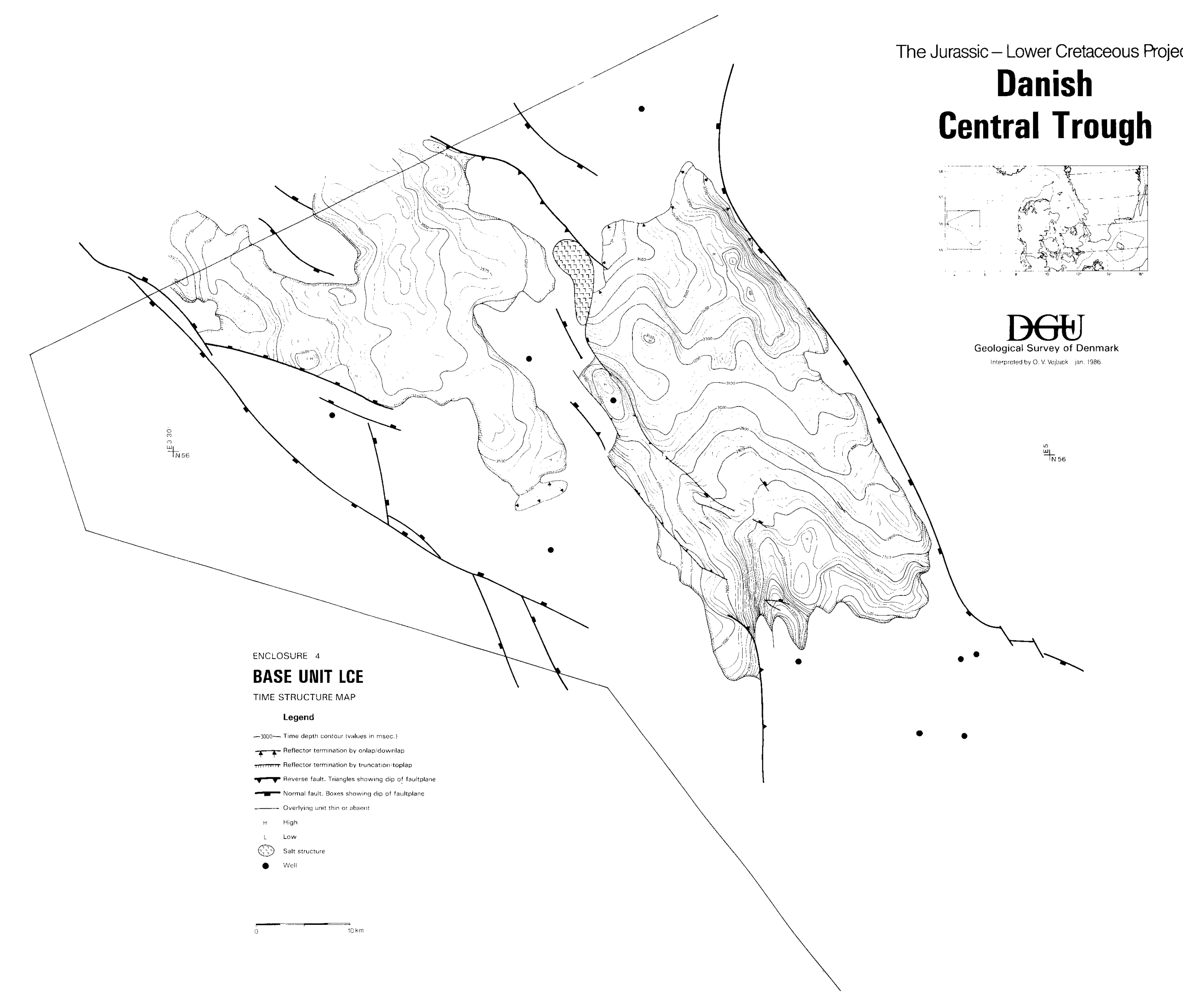




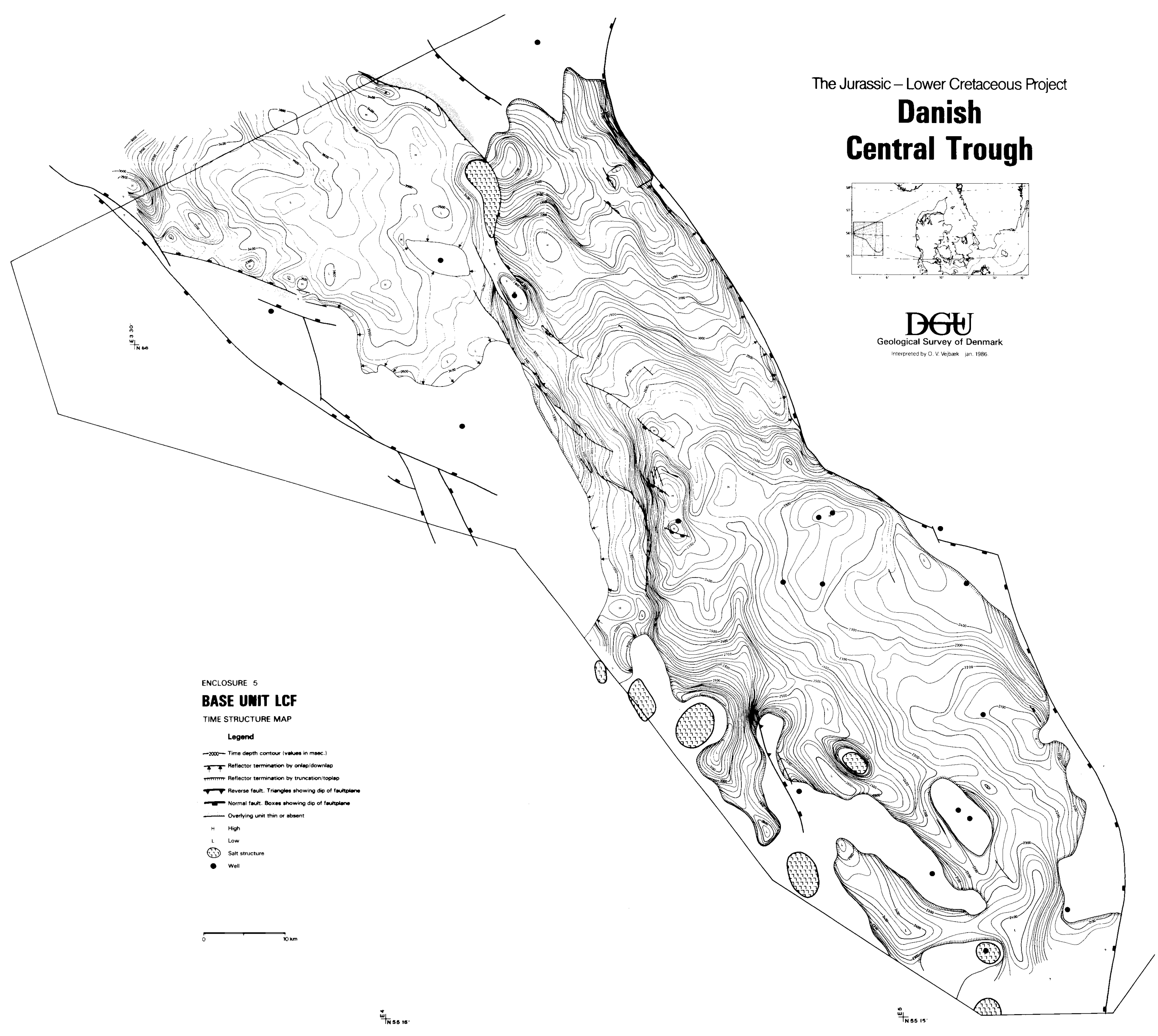




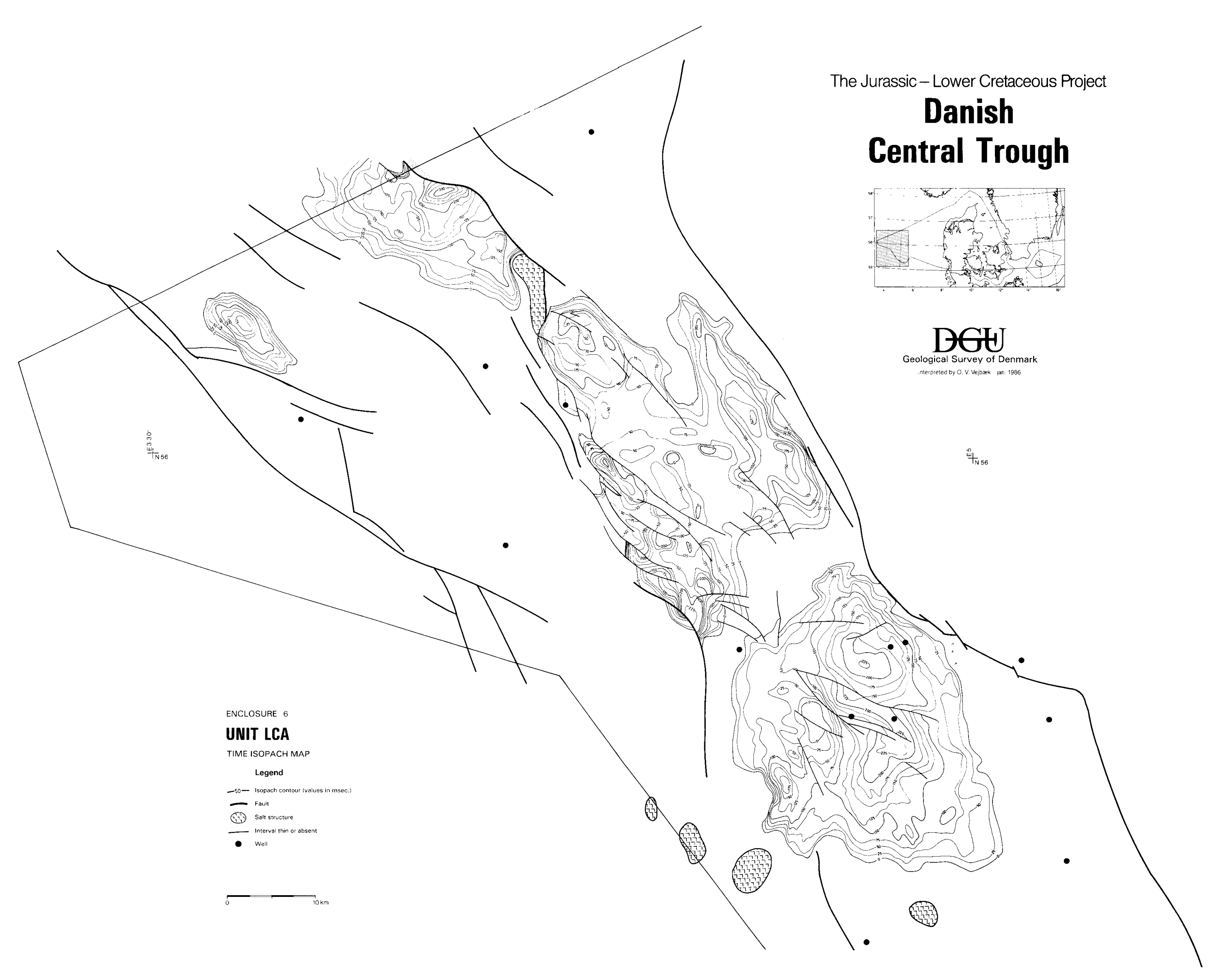




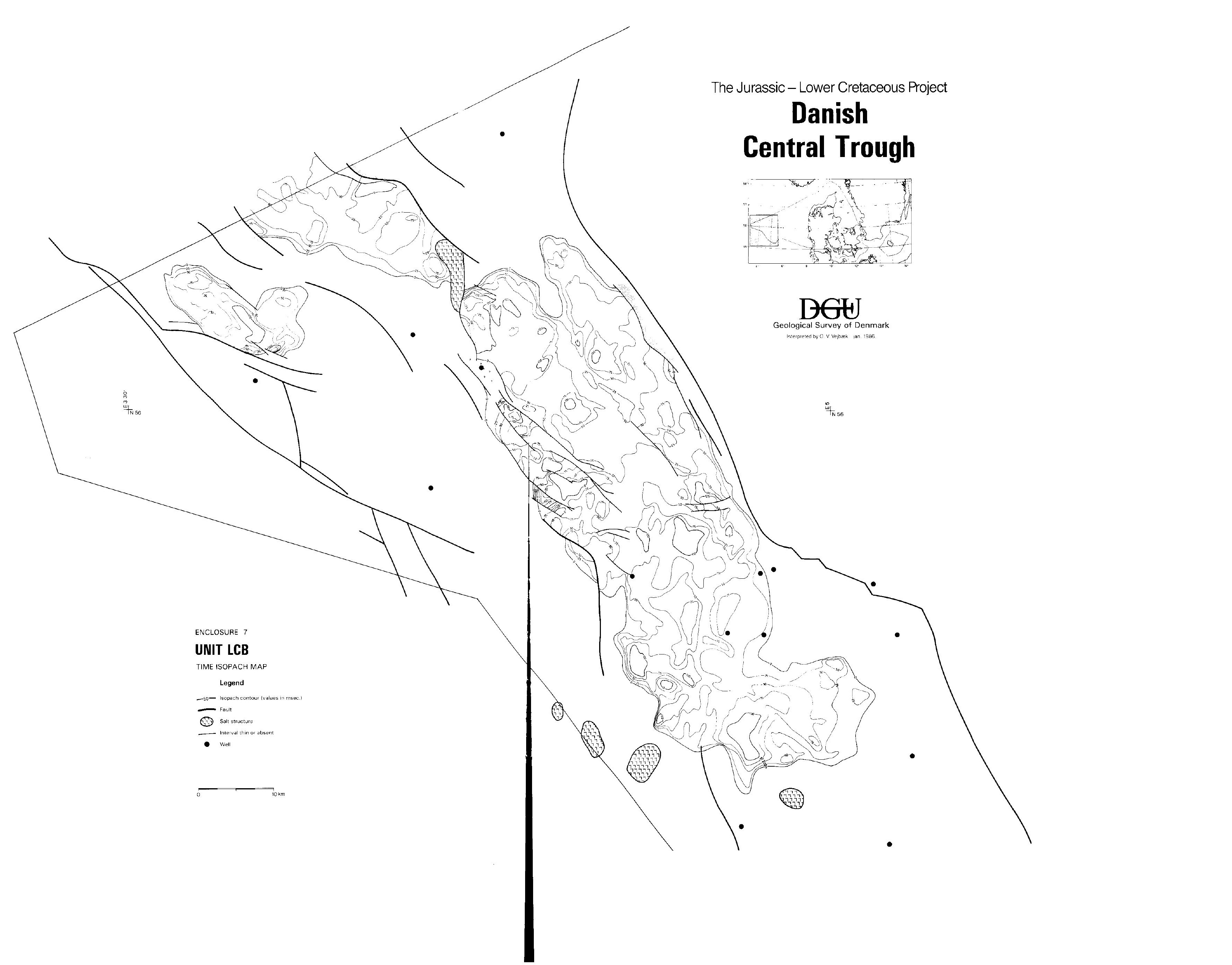




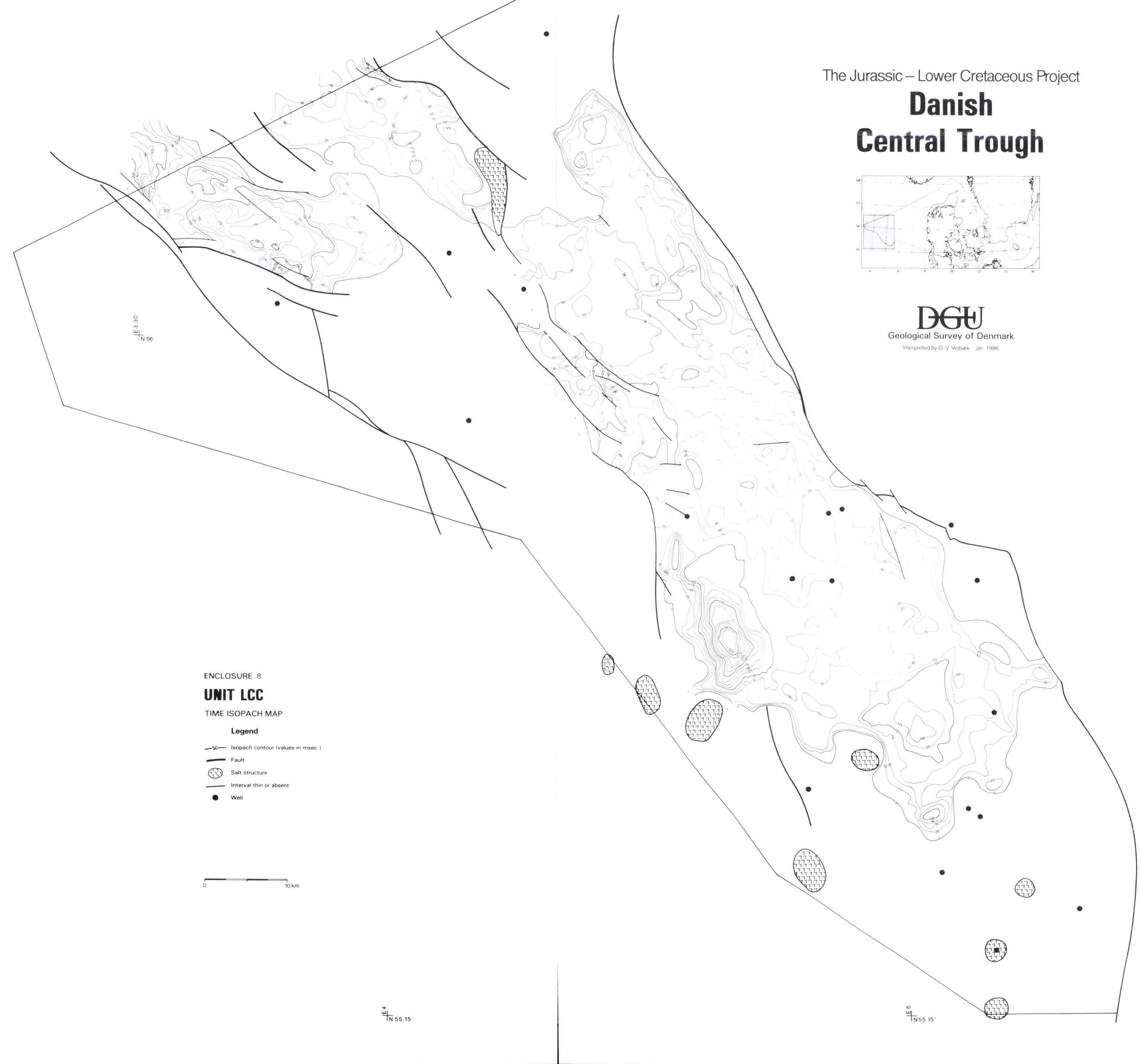




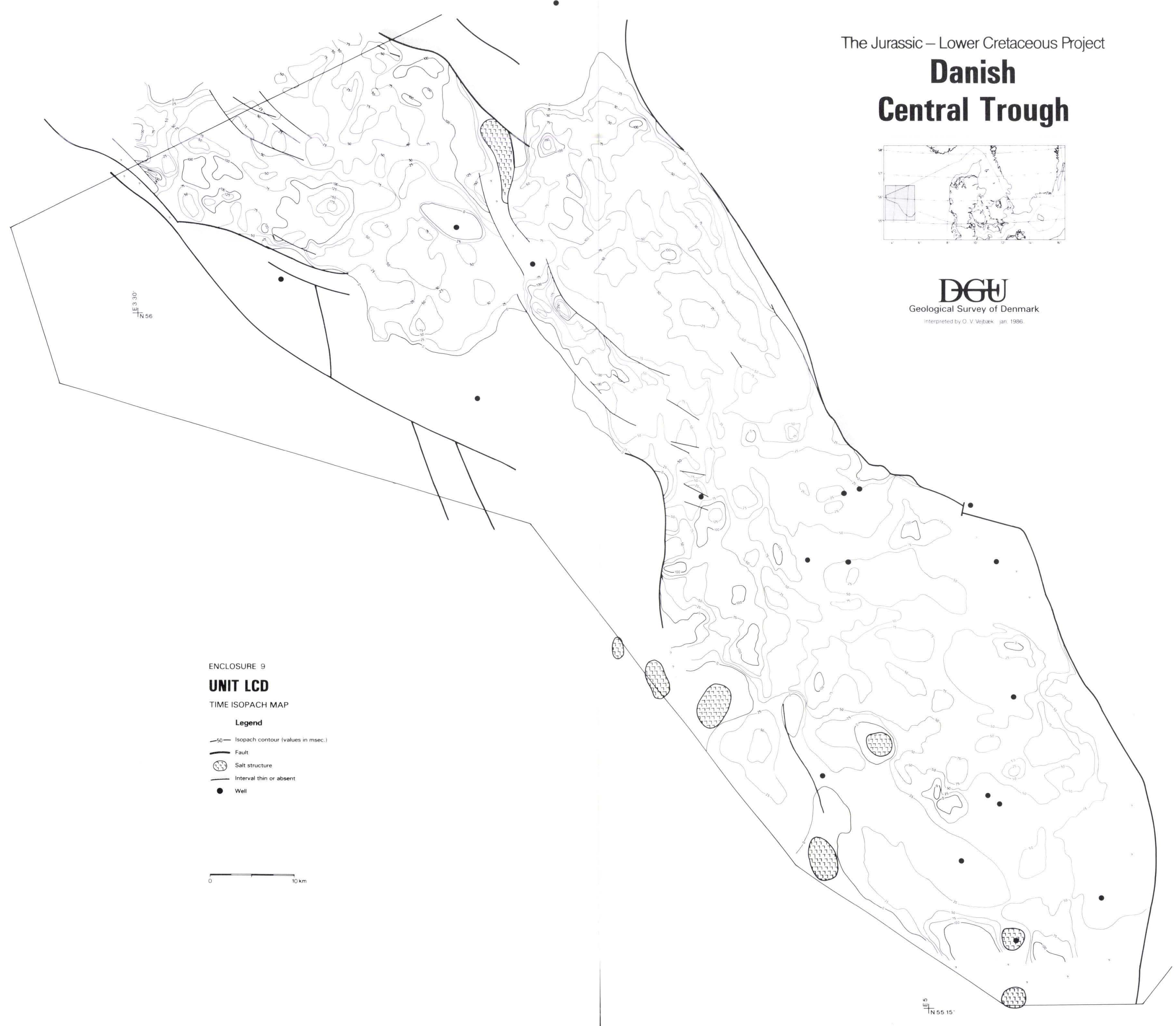


The Jurassic - Lower Cretaceous Projed

$$
\text { Danish }
$$

Central Trough

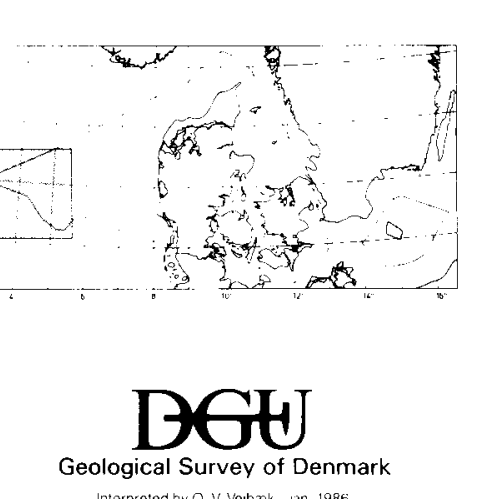

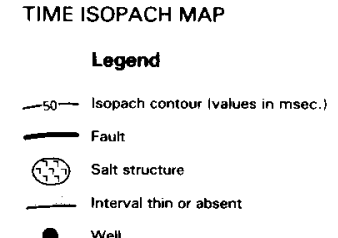

$\underset{-}{-}$ 


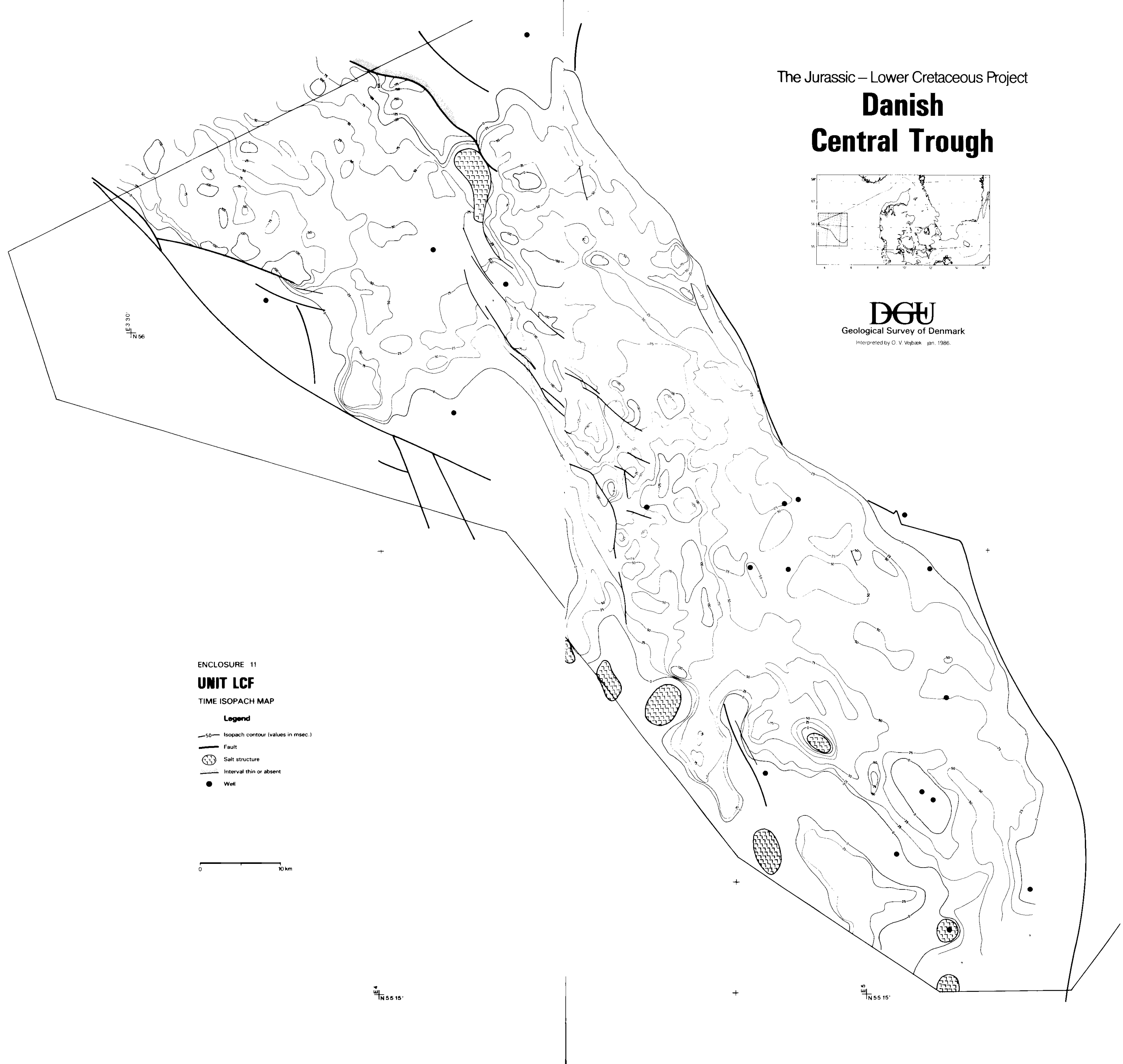


This paper presents a seismic stratigraphic analysis of the Lower Cretaceous of the Danish Central Trough. The tectonic development, the sedimentary evolution, sea level changes, and the Jurassic Cretaceous boundary are discussed based on seismic interpretation. 